Report upon the Parasitic Hymenoptera of the Island of St. Vincent. By C. V. Rilex, W. H. Ashmead, and L. O. Howard. (Communicated by D. SHarp, F.L.S., on behalf of the Committee for Investigating the Flora and Fauna of the West-Indian Islands.)

[Read 29th June, 1893.]

Introduction. By C. V. Riley.

WHEN the parasitic Hymenoptera and Rhynchota collected by Mr. Herbert H. Smith in the island of St. Vincent were sent to me some time ago by the West India Committee for study, I hoped to find time to work upon the collection myself, particularly in certain groups in which I have long taken an especial interest. This hope has proved vain, owing to the pressure of more urgent duties. While, however, I have been able to do but comparatively little work myself, I take pleasure in transmitting herewith a Report on the parasitic Hymenoptera by two of my assistants, Messrs. W. H. Ashmead and L. O. Howard, both of whom are well-known workers in this group of insects. Mr. Ashmead has studied the Braconidæ, Ichneumonidæ, Proctotrypidæ, and part of the Chalcididæ, the latter family possessing the largest number of forms. Mr. Howard has taken up the remainder of the Chalcididæ, comprising the subfamilies Chalcidina, Eucharina, Perilampine, Encyrtina, Elasmine, Aphelinina, Pirenina, and Elachistince. Six new genera and 299 new species are characterized. I have myself studied but have not yet completed the work on the Microgasterince in the Braconidæ, and the Eupelmina in the Chalcididæ; and hope to send before long a supplementary Report on these subfamilies.

The material collected by Mr. Smith has proved to be of very considerable interest. The groups containing the smaller $\mathrm{Hy}-$ menoptera have been so little collected, especially in the western hemisphere, that generalizations bearing upon the geographical range of species can hardly be attempted as yet, and such generalizations as may be made will have little value. It is interesting to note, however, that although the very large majority of the forms are new to science, a number of the old species collected in this island by the Rev. Lansdown Guilding during his residence there, and subsequently described by Francis 
Walkel, have been refound. A few of the old Fabrician species have also been recognized, while a number of forms common within the limits of the United States are also contained in the collection. These last are evidently species of wide distribution, since the characteristic fauna of St. Vincent must much more nearly resemble that of northern South America than of North America, or even of the subtropical portion of the Floridian peninsula.

It will appear from the portion of the Report contributed by Mr. Ashmead that nine of the species are common to St. Vincent and the United States, six occurring in the State of Florida, while the other three have a more porthern range. In the Chalcidids studied by Mr. Howard nearly three fourths are new, although not necessarily of subtropical limits. Nine of the previously described forms are characteristically tropical or subtropical ; one, curiously enough, has never before been found except in North Europe, and must evidently be considered an introduced species in St. Vincent; while four are North American, two being found commonly throughout the United States, one only in the district of Columbia, and one in Florida. The following list is, I believe, a fairly complete one of the previously described parasitic Hymenoptera found on the island of St. Vincent, those marked with a $*$ having been previously reported, while those without the $*$ are now recorded for the first time from the collection on which Messrs. Ashmead and Howard have reported; so that with the descriptive papers the list will comprehend all the parasitic Hymenoptera so far known from the island.

List of previously described Parasitic Hymenoptera found in St. Vincent.

Family CYNIPIDE.

Subfamily Eucoinina.

Eucoila, Westwood.

E. basalis, Cr. Proc. Ent. Soc. Phil. iv. p. 5 .

Eucoilidea, Ashmead.

E. canadensis, Ashm. Trans. Am. Ent. Soc. xiv. p. 154.

LINN. JOURN.-ZOOLOGI, VOL. XXV. 
Subfamily Figitixe.

Solenaspis, Ashmead.

S. bifoveolata, Cr. (Aspicera), Proc. Ent. Soc. Phil. iv. p. 7.

Family BRACONIDÆ.

Subfamily Spathinж.

Stenophasmus, Smith.

(?) S. pusillus, Cr. Proc. Ent. Soc. Phil. iv. p. 85.

Subfamily HecaвоLIN年.

Heterospilus, Haliday.

*H. quastor, Hal.

Subfamily Agathidinж.

Microdus, Nees.

M. varipes, Cr. Proc. Ent. Soc. Phil. iv. p. 65.

M. stigmaterus, Cr. l. c. p. 65 .

Subfamily Alysirñ.

Alysia, Latr.

A. analis, Cr. Proc. Ent. Soc. Phil. iv. p. 88.

Family ICHNEUMONID无.

Subfamily OpHIONINж.

Ophion, Fabr.

O. flavum, Fab. Ent. Syst. ii. p. 179.

O. concolor, Cr. Proc. Ent. Soc. Phil. iv. p. 56.

o. cubensis, Nort. l. c. p. 56 .

Еiphosoma, Cresson.

E. annulator, Cr. l. c. p. 54 .

\section{Family EVANIID五.}

Gasteruption, Latr.

*G. Guildingii, Westw. Trans. Ent. Soc. Lond. 185l, p. 219.

*G. rufipectus, Westw. l. c. p. 219.

Evania, Fabr.

E. appendigaster, Linn. Syst. Nat. i. p. 943. 
OF THE ISLAND OF ST. VINCENT.

Family CHALCIDID $\approx$.

Subfamily Eucharine.

Kapala, Cameron.

K. furcata, Fabr. Syst. Piez. p. 158.

\section{Orasema, Cameron.}

O. stramineipes, Cam. Biol. Cent.-Am., Hymen. i.p. 105.

Subfamily Eurytominж.

Decatoma, Spinola.

*D. oretilia, Walk. Ann. \& Mag. N. H. xii. p. 46.

Isosomodes, Ashmead.

I. gigantea, Ashm. Trans. Am. Ent. Soc. Phil. xiii. p. 127 .

Subfamily Chalcidina.

Spilochalcis, Thomson.

S. femoratus, Fabr. Syst. Ent. p. 375, no. 10 (1775).

*S. fulvescens, Walk. Ent. Mag. ii. p. 25.

\section{Chalcis, Fabr.}

C. annulatus, Fabr. Syst. Piez. p. 167.

Notaspis, Walk.

*N. formiciformis, Walk. Ent. Mag. ii. p. 37.

Antrocephalus, Kirby.

A. punctigerus, Fabr. Syst. Piez. p. 167.

Subfamily Blastophagine.

IDARNES, Walk.

*I. carme, Walk. Ann. \& Mag. N. H. xii. p. 47.

Paphagus, Walk.

*P. sidero, Walk. l. c. p. 48.

\section{Subfamily Spalanginare. \\ Spalangia, Latr.}

S. nigra, Latr. Gen. Crust. et Ins. iv. p. 29.

S. drosophila, Ashm. Trans. Am. Ent. Soc. Phil. xiv. 1887, p. 199.

Isocratus, Förster.

I. vulgaris, Walk. Ent. Mag. x. p. 114. 
Subfamily Pteromalina.

Cyrtogaster, Walk.

C. vulgaris, Walk. Ent. Mag. i. p. 382.

$$
\text { Lelaps, Haliday. }
$$

*L. pulchricornis, Hal. Ann. \& Mag. N. H. xii. p. 47.

Stenomalus, Thomson.

S. muscarum, Walk. Brit. Mus. Cat. p. 42 .

Catolaccus, Thomson.

*C. helice, Walk. Ann. \& Mag. N. H. xii. p. 46.

Subfamily Encyrtinæ.

Enasius, Walk.

*A. hyettus, Walk. Ann. \& Mag. N. H. xvii. 1846, p. 181.

Сомуs, Förster.

C. bicolor, How. U. S. Agric. Rep. 1880, p. 362, pl. 23 . fig. 3.

Leptomastix, Förster.

L. dactylopii, How. Bull. V., Ent. Bur. U. S. Dept. Agric. p. 23.

Encyrtus, Dalman.

E. tiliaris, Dalman, Kongl. Vet. Akad. Handl. 1820, p. 171.

Subfamily Aphelinine.

Coccophagus, Westwood.

C. Lecanii, Fitch, How. U. S. Agric. Rep. 1880, p. 360.

Subfamily Elachistinæ.

Euplectrus, Westwood.

*E. furnius, Walk. Ann. \& Mag. N. H. xii. p. 48.

Stenomesius, Westwood.

S. platynota, Howard in Hubbard's 'Orange Insects,' 1885, p. 217.

Subfamily Eulophina.

Hoplocrepis, Ashmead.

H. albiclavus, Ashm. Proc. Ent. Soc. Wash. i. p. 235. 
It may be well to call particular attention to the use of the generic name Ashmeadia by Mr. Ashmead in the opening portion of his section on the Eurytomince. In the 'Canadian Entomologist' during the closing months of 1889 Messrs. Ashmead and Howard discussed the priority of the use of the generic name Rileya, Mr. Howard having proposed it for a peculiar Encyrtine genus from California almost simultaneously with Mr. Ashmead's use of the same name for a Eurytomine genus from Florida. Mr. Howard, considering Rileya, Ashmead, to be a synonym of his own genus of the same name, proposed for the former the name Ashmeadia. With a view of ending a useless controversy, Mr. Ashmead, upon an expression of my own view, has consented to recognize Ashmeadia for the Eurytomine genus, leaving Mr. Howard's Encyrtine genus in possession of the name Rileya. In dedicating genera to individuals yet living, authors might avoid such possible conflict did they but first obtain the sanction of the person whom they intend to honour.

I cannot close these few notes of introduction without expressing my own sense of the obligation under which entomologists generally must rest to the West India Committee for carrying on this series of investigations ; and as the insect fauna of island after island is studied, the value of the results will proportionately increase.

Report on the Parasitic Cynipidæ, part of the Braconidæ, the Ichneumonidæ, the Proctotrypidæ, and part of the Chalcididæ.-Part I.* By William H. Ashmead.

Family CYNIPID无.

Subfamily Eucoiline.

Diglyphosema, Förster.

Digliphosema flavipes, sp. $\mathrm{n}$.

ㅇ. Length $1 \frac{3}{5}$ to 2 millim. Polished black; mandibles and palpi yellow ; antennæ black or dark brown, the first joint yellow ; legs, including coxæ, yellow. Head transverse, including the eyes a little wider than the thorax across from tegulæ to tegulæ,

* For Part II. see p. 108. 
which is the widest part. Eyes large, oval, convex. Cheeks distinctly margined, the lower portion finely, closely punctate. Face smooth, with two impressed lines that start between the base of the antennæ and the eye and extend into the lateral sutures of the clypeus; there is also a grooved line separating the cheeks from the face. Antennæ 13-jointed, submoniliform, as long as the body, the joints decreasing in length toward the tips. Thorax with two furrows that start from the anterior angles of the mesonotum and converge and extend back to the base of the scutellum, forming a long wedge-shaped carina; these lines are not deeply impressed and are quite different from those in my genus Eucoilidea. Collar visible above as a sharp carina. Pronotum slightly impressed and finely aciculated or striated at sides. Mesopleura smooth, highly polished, except a depression and some striæ just beneath the tegulæ; it is separated from the mesopectus by a straight line, and again divided at its basal onethird by an impressed line running parallel with the mesopectal suture. Metapleura scratched. Scutellum deeply foveated at base; its cup large, elliptical, with an elliptical central depression, surrounded by a submarginal punctate line; the sides of the cup finely, closely punctate. Metathorax short, depressed at the middle, with a central keel and rather prominent posterior lateral angles. Wings hyaline, pubescent, the venation yellowish; the marginal cell is large and open along the margin, the second abscissa of radius slightly curved and double the length of the first. Abdomen polished black, slightly piceous along the venter, slightly compressed, its tip abruptly truncate, the tip of the hypopygium visible.

Hab. St. Vincent.

Described from three female specimens.

Eucoilidea, Ashm.

Eucoilidea canadensis, Ashm. Trans. Am. Ent. Soc. vol. xiv. p. 154 (1887).

Hab. Canada; St. Vincent.

Four specimens are in the collection that cannot be distinguished from the type originally described from Canada. Three other specimens differ in having the legs entirely reddish yellow; while the four specimens have the coxæ and base of femora black. 


\section{Aglaotoma, Förster.}

Four species that evidently belong to this genus may be recognized as follows :-

\section{Females.}

Species black, except sometimes the metathorax and abdomen basally ....................... Species more or less pale rufous or brown.

Pale rufous, the occiput dusky.

Antennæ longer than the body, the eight terminal joints very slightly thicker than the preceding, the last joint one half longer than the penultimate; cup of scutellum very small, narrowed into a carina anteriorly, its disk wholly foveated $\ldots \ldots \ldots \ldots \ldots$ A. pallida.

Head black, thorax dark brown, abdomen, legs, and first four flagellar joints pale rufous.

Antennæ not longer than the body, the seven terminal joints slightly thicker than the preceding, the last joint one third longer than the penultimate; cup of scutellum elliptic, not narrowed into a carina anteriorly, its disk foveated, but divided into two parts by a transverse carina, the anterior part the larger............................... vabilis.

2. Wholly black; legs and six basal joints of antennæ yellowish.

Antennæ much longer than the body, the seven terminal joints thicker than the preceding, the last joint a little shorter than the penultimate; cup of scutelium elliptic, not narrowed into a carina anteriorly, its disk areolated $\ldots \ldots \ldots \ldots \ldots \ldots$ A. longicornis.

Metathorax, abdomen basally, and legs pale rufous or brownish yellow.

Antennæ scarcely longer than the body, the seven terminal joints thicker than the preceding, the last joint not longer than the penultimate; the cup of scutellum small, elliptic, not narrowed into a carina anteriorly, its disk smooth, polished, with a small fovea posteriorly

A. basalis.

\section{Males.}

Species black

Species pale rufous.

Third antennal joint slightly longer than the fourth, the joints beyond about four times as long as thick; 
cup of scutellum elliptic, its disk smooth, with a small fovea posteriorly and about six submarginal punctures anteriorly $\ldots \ldots \ldots \ldots \ldots \ldots \ldots \ldots$. pallida.

Head and abdomen black, the thorax piceous.

Third antennal joint not longer than the fourth, the joints beyond the fourth very slightly longer and thicker, about thrice as long as thick; cup of scutellum as in pallida ...............

A. variabilis.

2 Metathorax and legs yellowish.

Third antennal joint much longer than the fourth, thickened and curved, the joints beyond the fourth more than thrice as long as thick; cup of scutellum very small...................... basalis.

\section{Aglaotoma pallida, sp. n.}

o ㅇ. Length $1 \frac{2}{5}$ millim. Pale brown, polished, the occiput, in the female, black. Face with some fine longitudinal lines along the orbits. Antennæ in female 13-jointed, as long as the body, very slightly and gradually thickened toward tips, the joints long, cylindric; the first joint of funicle is scarcely longer than the second: in male longer than the body, filiform, the joints all long, cylindric; the first joint of funicle is slightly longer than the second and slightly bent, the following are a little contracted at base and apex and all finely fluted. Thorax smooth, without furrows, the prothorax visible above as a sharp, transverse carina. Cup of scutellum in male elliptical, its dorsum with a submarginal row of punctures and a fovea behind; laterally it is closely punctulate : in the female the cup is very small, narrowed, and extends into a carina anteriorly. Mesopleura polished, the epimera separated, in the male smooth, in the female finely, longitudinally aciculated. Metapleura smooth, bounded by a carina posteriorly. Metathorax short, with lateral carinæ and slightly pubescent. Wings hyaline, fringed, the venation brown, the marginal cell closed; the second abscissa of the radius is only about one fifth the length of the first. Abdomen highly polished, in male dark brown above, pale along the venter, with a slight hairy girdle at base.

\section{Hab. St. Vincent.}

Described from two male and one female specimen.

The female of this species agrees exactly with Förster's definition of the genus, but the male disagrees in not having the first joint of funicle " bermässig verlängert." 
Aglaotoma variabilis, sp. n.

o o. Length $1 \frac{1}{2}$ to $1 \frac{4}{5}$ millim. Polished, the head black, thorax brown; mandibles, four basal joints of flagellum, legs, and abdomen rufous, the latter blackish above; in the male the thorax is paler, the antennæ, except the three terminal joints, entirely black, the legs more yellowish. Antennæ in female 13-jointed, as long as the body, subclavate, all the joints long, cylindric, the seven terminal joints thicker than the preceding, black, but scarcely forming a distinct club; in the male 15jointed, filiform, nearly twice as long as the body, all the flagellar joints about equal in length, those in the middle being slightly dilated. Scutellum profoundly foveated at base, with deep channels around the cup, the latter with a pale margin and impressed at base and apex; in the male the cup is slightly larger, its dorsum smoother, foveated posteriorly and with six submarginal punctures anteriorly. Wings hyaline, fringed, the venation brown; the marginal cell is about two and a half times as long as wide, closed, the second abscissa of radius about one half longer than the first, both slightly curved. Abdomen highly polished, scarcely longer than the thorax, with a woolly girdle at base.

Hab. St. Vincent.

Described from one male and one female specimen.

Aglaotoma longicornis, sp. $\mathrm{n}$.

․ Length 2 millim. Polished black; six basal joints of antennæ, mandibles, and legs reddish yellow. Antennæ 13jointed, longer than the body, the flagellar joints all cylindric, but the seven apical joints thicker than the basal joints, black, fluted, and pubescent, a little more than thrice as long as thick; the four basal joints are very slender, the first slightly the shortest. Cup of scutellum elliptic, its dorsum areolated by irregular raised lines. Wings hyaline, fringed, the venation yellow; the marginal cell is very little more than twice as long as wide; the second abscissa of radius is about one third longer than the second, both slightly curved.

Hab. St. Vincent.

Described from a single specimen.

Aglaotoma basalis, sp. n.

ot ․ Length 1 millim. Polished black ; five basal antennal 
joints and legs yellow ; mandibles, metathorax, and base of abdomen rufous. Sometimes the whole abdomen is black. Antennæ, in female, scarcely longer than the body, 13 -jointed, cylindric, the seven apical joints slightly thickened, fuscous : in male 15 -jointed, twice as long as the body, fuscous, the joints all fluted; the first flagellar joint is one third longer than the second, curved, clavate. The cup of the scutellum in the male is very small, narrowed; in the female larger, elliptic, its dorsum smooth, with a fovea posteriorly and some punctures anteriorly. Wings hyaline, fringed, the venation pale brown; the marginal cell is closed, about twice as long as wide, the abscissas of radius about equal in length, the first being slightly curved.

Hab. St. Vincent.

Described from one male and three female specimens.

\section{Ganaspis, Förster.}

This genus, as recognized here, comes close to Aglaotoma; but the antennæ in the female are shorter, clavate, the six or seven terminal joints enlarged, submoniliform, much as in Hexacola, from which it differs, however, in baving a closed radial cell. In the male the first flagellar joint is scarcely longer than the second, not or only slightly curved.

The two species may be tabulated as follows:-

Entirely pale ferruginous or honey-yellow $\ldots \ldots \ldots \ldots$.

Pale ferruginous or honey-yellow, with the head black or

2. fuscous.

Six terminal joints moniliform, black, and, except the last, scarcely longer than thick.

First funicle-joint twice as long as the second, the second and third equal, longer than thick, the fourth and fifth small, moniliform. + ....... G. atriceps.

Three or four terminal joints black, and fully twice as long as thick

First funicle-joint very little longer than the second, the following all long, cylindric, thrice as long as thick. o $\ldots \ldots \ldots \ldots \ldots \ldots \ldots \ldots \ldots$ G. apicalis.

2. Antennæ 15-jointed, filiform, the three apical joints white. $\delta \ldots \ldots \ldots \ldots \ldots \ldots \ldots \ldots \ldots \ldots \ldots$ G. apicalis.

Antennæ 13-jointed, the three apical joints fuscous. $q$ variety (?)

G. apicalis. 
Ganaspis atriceps, sp. $\mathrm{n}$.

ㅇ. Length $1 \frac{2}{5}$ millim. Pale ferruginous, polished, the head and six terminal antennal joints black; mandibles and palpi pale. Antennæ 13-jointed, not longer than the thorax, the club 6 -jointed, the joints, except the last, scarcely longer than thick, black, delicately fluted; the first joint of funicle is twice the length of the second, the second and third equal, longer than thick, the fourth and fifth moniliform, not longer than thick. The scutellum at sides is finely rugose, its cup small, elliptic, with a small fovea posteriorly. Metathorax short, finely rugose, with a medial carina. Wings hyaline, fringed, the venation pale brown; the marginal cell is closed, a little more than twice as long as wide, the second abscissa of the radius being one third longer than the first, both slightly curved; cubitus visible. Abdomen not longer than the thorax, with the usual girdle at base.

Hab. St. Vincent.

Described from a single female specimen.

Ganaspis apicalis, sp. $\mathrm{n}$.

o 9 . Length $\frac{3}{5}$ to 1 millim. Pale ferruginous or honeyyellow ; the head in the female most frequently black or fuscous, rarely entirely pale as in the male. Antennæ in female 13jointed, about as long as the body, the six terminal joints enlarged, at least twice as long as thick, fluted, the three or four apical joints always black or fuscous; the first joint of funicle is cylindrical, a little longer than the second, the joints beyond, to the club, at least thrice as long as thick. In the male the antennæ are pale brown or slightly fuscous, 15-jointed, nearly twice the length of the body, with the three terminal joints always white. Scutellum at sides finely rugose; the cup in the male is small, arched, its dorsum smooth and polished, with only a small fovea posteriorly; in the female sometimes with two fover and sometimes with a forea posteriorly and punctures anteriorly. Abdomen a little longer than the thorax, with a woolly girdle at base.

Hab. St. Vincent.

Described from several specimens.

From the difference observed above in the scutellar characters, I suspect this species may really represent two distinct species; but, as the specimens are hardly sufficient for me to determine 
with certainty, I prefer for the present to let them remain together.

\section{Chrestosema, Förster.}

\section{Chrestosema robusta, sp. $n$.}

o . . Length $1 \frac{1}{2}$ to $1 \frac{4}{5}$ millim. A small, robust, polished black species. The head is transverse quadrate; the clypeus small, convex; mandibles and trochanters, tips of femora, tibiæ, and tarsi reddish yellow, the rest of the legs black. Antennæ in female filiform, submoniliform, shorter than the body, piceous, 13-jointed, the joints oblong-moniliform; the first funicle-joint is narrowed and slightly shorter than the second, the following joints are about the same thickness, but the five terminal joints are shorter than the five preceding: in the male longer than the body, filiform, the first funicle-joint is a little longer than the second, the following oblong-moniliform, about three times as long as thick. Thorax with two abbreviated, nearly parallel furrows anteriorly, that do not extend posteriorly quite to the middle of the mesonotum. The scutellum is separated from the mesonotum by deep foveæ; its cup is high, large, and almost round and centrally foveated, its sides vertically striated. Mesopleura smooth, with a small furrow below the tegulæ, the epimera separated, polished. Metapleura, except a small rugose space just above the coxæ, smooth, polished, the posterior margin carinated and pubescent, while on the disk is a faint impressed line. Metathorax very short, vertical, and closely punctate, with a delicate medial carina. Wings byaline, the venation yellowish; the marginal cell is closed, short, not longer than wide, the second abscissa of the radius being scarcely longer than the first and slightly curved outwardly. Abdomen not longer than the thorax, polished black, a slight pubescent girdle at base and with its tip vertically truncate.

Hab. St. Vincent.

Described from one male and one female specimen.

Chrestosema pallidipes, $\mathrm{sp}$. $\mathrm{n}$.

ㅇ. Length $1 \frac{1}{5}$ millim. Differs from the above in having the antennæ and legs, including the coxæ, entirely honey-yellow, athough the tips of the antennæ are sometimes dusky; face with two grooved lines, each line extending from the base of the antennæ to the base of the eye; while the cup of the scutellum 
has only a small fovea posteriorly, with a submarginal row of punctures, its sides being rugose, not vertically striated.

Hab. St. Vincent.

Described from two female specimens.

\section{Kieidotoma, Westwood.}

Kleidotoma insularis, sp. $\mathrm{n}$.

‥ Length 1 millim. Polished black; legs rufous, the middle and posterior coxæ black, all the femora more or less dusky. Antennæ 13-jointed, black, the three terminal joints much enlarged, fluted, the last the longest ; the basal joint is a little longer than the last, curved clavate, the second joint or the pedicel is oval; the following joints to the club are very slender; the third or the first joint of funicle is twice as long as the second, the joints following are rounded or moniliform and slightly increase in size. Wings hyaline, not emarginate at apex, the venation pale; the tip of the submarginal vein terminates in a quadrate stigma, the marginal cell is open along the outer edge and is nearly twice as long as wide, the first abscissa of radius very oblique, a little longer than the second. Abdomen as long as the thorax, polished, compressed, without a pubescent girdle at base and with a very finely aciculated spot at base above.

Hab. St. Vincent.

Described from one female specimen.

\section{Tetrarhapta, Förster.}

Tetrarhapta rufipes, sp. $\mathrm{n}$.

․ Length 1 millim. Polished black; antennæ and legs reddish yellow, the four terminal joints of antennæ enlarged, fluted, and fuscous. Antennæ 13-jointed, the first joint scarcely longer than the oval second ; the funicle-joints are slender, cylindrical, the first joint one third longer than the second, the joints beyond becoming gradualy subequal; club 4-jointed, the joints two and a half times as long as thick. The cup of the scutellum is small, high, and narrowed, with a central fovea, the sides closely punctate. Wings hyaline, pubescent, with long marginal ciliæ, the venation brown; the marginal cell is closed, triangular, slightly longer than wide, the first and second abscissas of the radius straight and about of an equal length. Abdomen very 
slightly longer than the thorax, polished, with a pubescent girdle at the base.

Hab. St. Vincent.

Described from a single specimen.

\section{Pentackita, Förster.}

\section{Pentacrita obscuripes, $\mathrm{sp}$. $\mathrm{n}$.}

q. Length 1 millim. Polished black; antennæ brown; legs reddish yellow, the middle and posterior coxæ black, their femora more or less dusky or black. Antennæ 13-jointed, the five terminal joints enlarged, moniliform, the last joint a little the longest; basal joint twice as long as the pedicel, which is rounded; the funicle-joints are more slender, submoniliform, the first about twice the length of the second, the joints beyond very gradually increasing in length and width to the club. The cup of the scutellum is very small, with a slight fovea posteriorly ; anteriorly it is smooth, the sides rugose. Metathorax pubescent. Wings hyaline, fringed, the venation yellow; the marginal cell is about one half longer than its width, closed, the first abscissa straight and slightly shorter than second, which is slightly curved outwardly. Abdomen polished black, as long as the head and thorax together and with a pubescent girdle at base.

Hab. St. Vincent.

Described from a single specimen.

\section{Leptopilina, Förster.}

Leptopilina Mindta, sp. $\mathrm{n}$.

․ Length $\frac{4}{5}$ millim. Polished black; antennæ brown; legs flavo-testaceous, the posterior femora brownish. Antennæ 13jointed, about as long as the body, the seven terminal joints cylindrical, about thrice as long as thick, and thicker than the basal funicle-joints, which are slender; the first funicle-joint is about one third longer than the second; scape and pedicel swollen, the latter globose. Scutellum rather high, slightly projecting over the metathorax, which is short, and abruptly declining posteriorly; the cup is small, elliptic, its dorsum smooth, with a few round punctures. Metathorax short, with two delicate medial carinæ. Wings hyaline, strongly fringed, the apex with a slight sinus, the venation pale brownish yellow; the marginal cell is closed, about twice as long as wide, the second abscissa of 
radius very slightly longer than the first. Abdomen not longer than the thorax, polished, with a very slight pubescent girdle at base.

Hab. St. Vincent.

Described from a single specimen.

\section{Heptameris, Förster.}

HePtTameris RUFipes, sp. $\mathrm{n}$.

ㅇ. Length $1 \frac{1}{2}$ millim. Polished black; antennæ brownish, the two basal joints black; legs reddish yellow. Antennæ 13-jointed, subclavate, the seven terminal joints thicker than the preceding, not fluted, the last joint the longest, one half longer than the preceding; the first funicle-joint is one half longer than the second, the second and third equal, the fourth as long as the first. Scutellum at sides finely rugose, its cup elliptic, and connected with the mesonotum by a delicate carina, its dorsum with a small fovea posteriorly and with some punctures anteriorly. Wings hyaline, sparsely pubescent, and with short ciliæ, the venation yellowish; the marginal cell is open along the outer margin, a little more than one and a half times as long as wide, the second abscissa of radius about one third longer than the first, both straight. Abdomen as long as the head and thorax together, black, polished, piceous beneath towards the base, and with a distinct woolly girdle.

Hah. St. Vincent.

Described from one specimen.

Heptameris flavipes, sp. n.

f. Length $1 \frac{3}{4}$ millim. Differs from $H$. rufipes in having black antennæ, except the three or four basal funicle joints, which are piceous, the 7 apical joints fluted; the first funicle-joint is only slightly longer than the second, the three following about equal; the cup of scutellum is small, elliptic, its dorsum smooth, not foveated: while the second abscissa of the radius is one and a half times as long as the second; the metapleura pubescent.

Hab. St. Vincent.

Described from two specimens.

Hypolethria, Förster.

HYPolethria LONGicornis, sp. n.

ㅇ. Length $1 \frac{4}{5}$ millim. Polished black; the five basal joints 
of the antennæ and the legs honey-yellow. Antennæ 13jointed, longer than the body, all the flagellar joints long, cylindric, the 7 or 8 terminal joints slightly thickened and delicately fluted, averaging about thrice as long as thick; the first funicle-joint is about as long as, or very slightly shorter than, the second. Cup of scutellum large, broadly oval, nearly round, its dorsum excavated and with some punctures, the outer margin piceous. Abdomen as long as the thorax, polished black, with a woolly girdle at base; the hypopygium prominent, acute, ploughshare-shaped, piceous. Wings hyaline, pubescent, the marginal cell closed, about two and a half times as long as wide, the cubitus more or less distinct; the second abscissa of the radius is about one and a half times as long as the first, very slightly bent. One specimen has the apex of the wings slightly emarginate.

Hab. St. Vincent.

Described from three specimens.

Hexacola, Förster.

This genus is represented by three closely allied species, which may be separated as follows :-

\section{Females.}

Dorsum of cup smooth, polished, with a small fovea posteriorly and two punctures anteriorly; antennæ black.

Posterior coxæ black, all femora dusky ....... H. solitaria.

Dorsum of cup smooth, polished, with a small fovea posteriorly, and four punctures anteriorly; antennæ brown or fuscous.

All coxæ and legs yellow or reddish yellow.

The five funicle-joints together not longer than the three basal joints of club, the four apical joints of the funicle not longer than wide... H. modesta.

The five funicle-joints together much longer than the three basal joints of club, the four apical joints of funicle longer than wide........

H. Sancti-Vincenti.

\section{Males.}

First flagellar joint much longer than the second, clavate, slightly curved.

Flagellar joints after the first thrice as long as thick; the dorsum of cup with two punctures. H. solitaria. 
Flagellar joints after the first less than thrice as long as thick; the dorsum of cup with four punctures ....................... Sancti-Vincentı.

First flagellar joint not longer than the second.

Flagellar joints about twice as long as thick; the dorsum of cup with four punctures $\ldots \ldots \ldots$ H. modesta.

Hexacola solitaria, sp. n.

o 9 . Length 1 millim. Polished black; mandibles rufous; antennæ black, the funicle-joints piceous; legs reddish yellow, the posterior coxæ and ail femora more or less black or dusky. Face with deep lateral clypeal sutures. Antennæ 13-jointed, not reaching to the middle of the abdomen, the six terminal joints enlarged; the five funicle-joints together are scarcely longer than the three basal joints of club, the first joint is almost twice as long as the second, the-second and the following moniliform; the joints of the club, except the last, are scarcely longer than thick, delicately fluted and pubescent. Cup of scutellum small, elliptic, its dorsum smooth, polished, with a small fovea posteriorly and two punctures, its sides being finely longitudinally striated. Tegulæ black. Wings hyaline, strongly fringed, the venation yellowish; the marginal cell is about once and a half as long as wide, the outer margin open toward the apex, the second abscissa of radius very slightly longer than the first, straight, the second very slightly arched inwardly. Abdomen as long as the thorax, polished, with a distinct woolly girdle at base.

The antennæ in the male are 15-jointed, brown-black, the third joint being clavate, a little curved, and one third longer than the fourth, the joints beyond being about thrice as long as wide and all fluted; legs reddish yellow; tegulæ piceous. Otherwise in the scutellun, venation, \&c. it is identical with the female.

Hab. St. Vincent.

Described from two specimens, a male and female.

Hexacola modesta, sp. .

$0^{7}$ ㅇ. L Length $\frac{4}{5}$ to 1 millim. Polished black; mandibles yel lowish; antennæ brown or piceous ; legs honey-yellow or reddis! yellow, the femora rarely infuscated. Antennæ 13-jointed, ex. tending scarcely beyond the base of the abdomen, the six ter. minal joints enlarged, moniliform ; the five funicle-joints together

LINN. JOURN.—ZOOLOGY, VOL. XXV. 
are not longer than the three basal joints of the club, the first joint the longest, the four following small, moniliform, not longer than wide. Cup of scutellum small, elliptic, its dorsum polished, with a small fovea posteriorly and four punctures anteriorly, the sides aciculated. Tegulæ rufo-piceous. Wings hyaline, strongly fringed, the venation pale brownish; the marginal cell is about once and a half as long as wide, open along the outer margin, the second abscissa of the radius about one fourth longer than the first, both being straight. Abdomen as in previous species, a little piceous beneath.

In the male the antennæ are very long, brown or black, the third joint not longer than the fourth, the joints beyond about twice as long as thick, while the first abscissa of the radius is very slightly bent.

Hab. St. Vincent.

Described from two male and seven female specimens.

Hexacola Sancti-Vincenti, sp. n.

$0^{\star}$ 우. Length 1 to $1 \frac{1}{5}$ millim. Polished black; mandibles and palpi pale rufous; antennæ brown, more or less dusky toward the tips; legs yellow or reddish yellow. The antennæ are 13-jointed, extending fully to the middle of the abdomen, the six terminal joints moniliform, longer than thick; the five funicle-joints together are always much longer than the three basal joints of the club, the joints longer than wide, the first one being about twice as long as the second. Scutellum as in H. modesta. Tegulæ piceous. Wings hyaline, strongly ciliated, the venation yellowish; the marginal cell is less than twice as long as wide, open along the margin, the first and second branches of the radius about equal, slightly curved. Abdomen as in previous species.

In the male the antennæ are much longer than the body, brown, the third joint much longer than the fourth, slightly curved, clavate, the following joints about twice as long as thick; the legs yellow.

Hab. St. Vincent.

Described from many specimens.

\section{RHoptromeris, Förster.}

RHOPTROMERIS INSULARIS, sp. $n$.

ㅇ. Length $1 \frac{3}{5}$ millim. Polished black; mandibles and palpi 
yellowish; six basal joints of antennæ pale brown, the seven terminal joints black; legs yellow. Antennæ 13-jointed, the seven terminal joints enlarged, about one fourth longer than thick, fluted; the four funicle-joints are slender, the first the longest, the following subequal, longer than thick. Scutellum rugose at sides, the cup not large, elliptic, narrowed a little at base, the outer margin yellow, the disk excavated. Wings hyaline, ciliated, the venation pale; the marginal cell is less than once and a half as long as wide, open along the outer margin, the second abscissa of radius being but slightly longer than the first. Abdomen scarcely longer than the thorax, polished, with a woolly girdle at base.

Hab. St. Vincent.

Described from a single specimen.

\section{Eucoila, Westw.}

Several distinct species in this genus are in the collection, and may be separated as follows :-

Moderate-sized species.....................

Large species.

Abdomen and legs rufous.

Dorsum of cup divided into two nearly equal parts by a transverse carina.

Collar with a tuft of yellow hairs on each side, its projecting ridge deeply emarginated at the middle $\ldots \ldots \ldots \ldots \ldots \ldots \ldots \ldots \ldots \ldots$ E. basalis, Cr.

2. Legs, including coxæ, yellowish or rufous.

Sides of scutellum areolated, its cup small, much elevated posteriorly, and produced into a long carina anteriorly ; metathorax more or less rufous, pubescent, its neck rugose $\ldots \ldots \ldots \ldots \ldots \ldots \ldots \ldots \ldots . . . \ldots$. claripennis.

Sides of scutellum finely rugose, its cup rather large, broadly oval, without a carina anteriorly, its dorsum smooth, with a transverse fovea behind, and about six punctures surrounding the margin anteriorly; metathorax black, almost bare, its neck striated .. E. ovalis.

Eucoila basalis, Cr. Proc. Ent. Soc. Phil. iv. p. 5. Hab. Cuba and St. Vincent.

A large series of this species was taken by Mr. Smith. 
Eucoila claripennis, sp. n.

․ Length $2 \frac{1}{2}$ millim. Polished black; metathorax dull rufous ; mandibles, antennæ, except toward tips, and the legs rufous. Antennæ 13-jointed, gradually incrassated toward tips, submoniliform, the four terminal joints black, the first flagellar ioint a little longer than the second. Collar with a tuft of yellowish hairs at sides, the transverse ridge only slightly emarginated. Scutellum piceous, areolated at the sides, the cup very small, elevated posteriorly, and extending anteriorly into a carina. Metathorax carinated, pubescent. Wings hyaline, subpubescent, but with a short marginal fringe; the marginal cell is a little less than twice as long as wide, the second abscissa of the radius being once and a half as long as the first, the latter slightly curved. Abdomen as long as the head and thorax together, polished black, with a distinct woolly girdle at base.

Hab. St. Vincent.

Described from three specimens.

Eucoilla ovalis, sp. n.

ㅇ. Length 2 millim. Polished black; mandibles and legs reddish yellow ; antennæ yellowish, the six apical joints fuscous. Antennæ 13-jointed, gradually incrassated toward tips, submoniliforı; the first joint of funicle one third longer than the second, cylindric, the four following subequal, the six terminal joints fluted, about once and a half as long as thick, the last the largest. Collar with a few pale glittering hairs at the sides, the transverse ridge scarcely emarginated at the middle. Scutellum finely rugose at the sides, the cup rather large, broadly oval, with a pale rim, the dorsum smooth, with a small fovea posteriorly and about six submarginal punctures anteriorly. Metathorax short, nearly bare, carinated. Wings hyaline, pubescent, the venation yellow; the marginal cell is about once and a half as long as wide, the second abscissa being about one fourth longer than the first, straight; the first is very slightly curved. Abdomen as long as the head and thorax together, polished black, piceous along the venter, with a distinct woolly girdle at base.

Hab. St. Vincent.

Described from two specimens. 
(?) Eucoila carinata, Cr. l. c. p. 6.

Fib. Cuba.

ANeCtoclis sp.

Anectochis, Förster.

․ Length $2 \frac{1}{5}$ millim. Polished black; mandibles black; antennæ piceous; legs reddish yellow. Antennæ 13-jointed, submoniliform, gradually incrassated toward tips, the first flagellar joint scarcely longer than the second. Transverse ridge of collar deeply emarginated at the middle. Scutellum rugose at sides, the cup elliptic, its margins pale, the dorsum with a fovea posteriorly and several punctures anteriorly. Metathorax short, pubescent, the metapleura with a pubescent ridge posteriorly. Wings hyaline, pubescent, the venation yellow; the marginal cell is about twice as long as wide, entirely open along its outer margin, the second abscissa of radius very slightly curved and almost twice as long as the first, which is straight. Abdomen as long as the head and thorax together, polished black, piceous beneath toward base, and with a woolly girdle at base.

Hab. St. Vincent.

Described from a single specimen.

\section{Hexaplasta, Förster.}

The genera Hexacola and Hexaplasta, Förster, are very similar, and are separated upon very slight characters; it is often a matter of guesswork to place the species, the slight difference in the cup of the scutellum, used by Förster, being probably not sufficient to separate them. Of the former he says :- "Schildchen an der Spitze zugerundet, scharf gestreift, der Napf nicht gross, elliptisch, mit einem Grübchen am Hinterrande ;" of the latter :- "Schildchen kaum gestreift, Napf gross, flach, glatt und glänzend, hinter mit einem runden Grübchen;" so that virtually the only difference is in the size of the cup.

The following species, in having the cup large, agrees with this definition, and is described under this genus.

\section{Hexaplasta incerta, sp. n.}

ơ 우. Length $1 \frac{1}{5}$ to $1 \frac{4}{5}$ millim. Polished black; mandibles and legs reddish yellow; antennæ variable from piceous to yellow, the terminal joints usually dusky or black. Antennæ 
13-jointed, the six terminal joints enlarged; the first joint of funicle is a little longer than the second, the following all longer than thick. Transverse ridge of the collar truncate, scarcely emarginate at the middle. Scutellum rugose at the sides, the cup large, broadly oval, the rim pale, the dorsum smooth, polished, with a small fovea posteriorly and about six submarginal punctures anteriorly. Wings hyaline, fringed, the venation yellow; the marginal cell is usually closed, rarely slightly open along the margin towards the apex, and less than twice as long as wide; the first abscissa of the radius is a little shorter than the second and slightly arched. Abdomen as long as the head and thorax together, black, polished, with a hairy girdle at base.

The male has long, brown-black, 15-jointed antennæ, the three basal joints paler ; the first flagellar joint is not longer than the second, the following about equal, thrice as long as thick, fluted, hairy.

Hab. St. Vincent.

Described from one male and twenty female specimens.

Subfamily Figitina.

Solenaspis, Ashmead.

Solenaspis bifoveolata, $C r$.

Aspicera bifoveolata, Cr. Proc. Ent. Soc. Phil. iv. p. 7.

Hab. Cuba, St. Vincent.

Sixteen specimens of what is undoubtedly this species are in the collection.

Solenaspis Rufipes, $C r$.

Aspicera rufipes, Cr.l. c. p. 7 .

Hab. Cuba.

Subfamily Cynipine.

Crnips, Linn.

Crnips (?) armatus, Cr. Proc. Ent. Soc. Phil. iv. p. 4.

Hab. Cuba.

Without doubt this species will prove to be one of the Figitids. 
Report on the Chalcididæ of the Subfamilies Chalcidince, Eucharince, Perilampina, Encyrtina, Aphelinina, Pirenina, Elasmince, and Elachistince. By L. O. Howard.

Subfamily Chalcidine.

SpIlochalcis, Thomson.

\section{Spilochalcis Femoratus.}

Crabro femoratus, Fabr. Syst. Ent. p. 375, no. 10 (1775).

Sphex punctata, Fabr. Spec. Ins. i. p. 446 (1781).

? Chalcis fasciata, Oliv. Enc. Méth. v. p. 439, no. 9 (1790).

Smicra subpunctata, Walk. Ent. Mag. ii. p. 25 (1834).

Smicra nigropicta, Cress. Proc. Ent. Soc. Phil. iv. p. 55 (1865).

Smicra dorsivittata, Cameron, Biol. Cent.-Am., Hym. i. p. 90, pl.v. fig. 2.

Smicra femorata (Fabr.), Kirby, Linn. Journ., Zool. xvii. p. 66.

This handsome species is represented in a series of 29 male and female specimens which show surprisingly little variation. I have seen a single specimen from Jamaica.

\section{SPILOCHALCIS FULVESCENS.}

Smicra fulvescens, Walker, Ent. Mag. ii. p. 25.

Smicra fulvescens, Walker, Cresson, Trans. Am. Ent. Soc.iv. p. 56.

The 109 male and female specimens which the St. Vincent collection contains show an extraordinary variation in size, from 4 millim. to 12 millim. in length, but are otherwise constant.

\section{Spilochalcis Nigritus, sp. $\mathrm{n}$.}

Average length 3.3 millim.; expanse 5.6 millim. Hind femora with 17 teeth beneath; petiole of abdomen about one half the length of the hind coxa. General colour black, with rather close, short, whitish pubescence; mandibles yellow; a yellow spot at insertion of antennæ; margin of eyes behind narrowly yellow, and a short spot in middle of front eye-margin; two small contiguous yellow spots in middle of hind margin of pronotum and two still smaller on either side, one on hind margin and one a little before and mesiad of this; a small yellow spot a little before middle of each parapsidal furrow of mesoscutum; a larger roundish yellow spot on each side of mesoscutellum; an irregular transversely oval light lemon-yellow spot each side of dorsum of third abdominal segment (counting petiole as first); trochanters faintly yellowish at tips; all femoro-tibial knees yellow; all tibiæ yellow, with a black band in centre; all tarsi light yellow; 
hind femora with a single small yellow spot above, and a larger one just at knee. Wings hyaline, veins dark brown, the white interruption at juncture of submarginal with marginal very distinct.

Described from twenty male and female specimens from St. Vincent. Comes nearest to S. torvina (Cresson).

\section{Spilochalcis misturatus, sp. $\mathrm{n}$.}

Length 2.5 millim.; expanse 3.7 millim. Hind femora with 12 teeth below; petiole of abdomen one half as long as hind coxa, spur at base below long and slender; terebra exserted, one third as long as abdomen. Antennæ yellow, brownish at tip; head yellow, occiput dark brown, face with two faint brownish longitudinal stripes, wider above than below; prothorax entirely yellow; mesoscutum brown, rather bronzy, with two broad yellow stripes down the mesial margin of the parapsidal sutures; mesoscutellum yellow, with a large central brown spot, scapuiæ brown; metanotum and petiole yellow; meso- and metapleura and mesosternum dark brown, nearly black; abdomen light brown, darker at sutures, with a complete yeilow band on anterior border of third segment; pygidium black at tip; all legs light yellow, hind coxæ with a black spot above at base, and hind femora with a brownish shade on outer basal half and another at curve of tip; teeth of hind femora black. Wings hyaline, veins dark brown.

Described from three female specimens. St. Vincent.

\section{Chalcis, Fabricius.}

\section{Chalcis annulatus.}

Chalcis annulatus, Fabricius, Ent. Syst. ii. pp. 197-9 ; Systema Piezatorum, p. 167.

Length variable, the largest specimens measuring 6 millim., and the smallest 3 millim.; expanse of largest specimens from 9 to 10 millim. Cheeks very delicately punctured; genal sulcus sharp and deep; clypeus with a few sparse round punctures, and with a double impressed line just below its juncture with the epicranium; above this line is a single transverse row of round punctures; vertex and dorsum of thorax closely and rather coarsely punctate, the punctation of metanotum being almost reticulate from its coarseness; abdomen smooth; all body except 
first abdominal segment with short yellowish pile, which is very abundant at tip of mesoscutellum; on second abdominal segment this pile is present only in two dorso-lateral patches, but in following segments there is a deep fringe from the border of each; hind femora with 11 teeth below, first and eleventh largest, the others well separated, except 8,9 , and 10, which are shorter and close together. Colour black; tegulæ, with the exception of three minute black spots, bright yellow ; apical third of front and middle femora bright yellow, the line of juncture between the black and the yellow on the outer surface oblique: front and middle tibiæ yellow except a black pateh on the outer middle; all tarsi yellow; hind femora with a single rather large yellow patch at upper tip extending into the black of the outer surface for a little over one fourth the length of the femur; hind tibiæ black at base and with a sharp black band a little beyond middle, being thus divided approximately into alternate black and yellow fourths; wings hyaline, veins dark brown except basal half of submarginal vein of hind wings, which is bright yellow.

Eighteen male and female specimens from different parts of the island of St. Vincent.

\section{Antrocephalus, Kirby.}

\section{Antrocephalus punctigerus.}

Chalcis punctigera, Fabr. Syst. Piez. p. 167, no. 31. South America.

There is some doubt both as to the generic and specific placing of this form, which is represented in the St. Vincent collection by 29 males and 35 females. It corresponds closely with the very brief diagnosis of the genus given by Kirby (Linn. Soc. Journ., Zool. xvii. p. 63), but this description is incomplete, and the types, Halticella fascicornis, Walk., and H. diversicornis, Walk., belong to the South Asiatic fauna. It is plainly distinct, however, from any other Chalcidine genus, as defined by Kirby. It is the female antenna which is figured and described by Kirby. That of the male differs considerably. It is apparently only 11jointed, since but one dividing suture in the club can be seen. The scape is much shorter, being less than one fifth the length of flagellum, and reaches only to middle of eyes. The pedicel is very short, about as broad as neck of scape, and about as long as broad. Joint 1 of funicle is suddenly broader, nearly twice as 
broad as pedicel and twice as long as broad. The other funiclejoints are stout, cylindrical, and all of the same diameter; joint 1 is longest, and the rest diminish gradually in length to 7 . The club is rounded at tip, and is slightly longer than joint 7 of funicle. The generic description states that the hind femora are unarmed, but the figure (pl. iv. fig. 25) shows a series of short, close, and extremely minute teeth or bristles, 20 in number, on the outer half of the lower border. This is substantially the case with the St. Vincent specimens. The projections are exceedingly minute teeth about 35 in number.

Fabricius's Chalcis punctigera has not, I believe, been redescribed ; hence we may safely apply the name to this form, since the few words of description fit sufficiently well.

․ Length 3.3 millim.; expanse 5.8 millim. Head and thorax with rather close, large, roundish punctures, and with sparse light yellow pile; segments $3,4,5$, and 6 , and pygidium of abdomen with close white pile; pygidium with a slight central longitudinal dorsal carina; metascutellum with two median longitudinal parallel carinæ; attached to each of these at top and bottom is an outwardly curved bow-shaped carina ; rest of metanotum reticulate; fimbria sparse, silvery white; basal constricted half of first abdominal segment longitudinally striate, with a more marked central longitudinal carina. Colour black; pedicel and funicle-joints 1-4 of antenna dark honey-yellow; tegulæ brown ; all trochanters and tarsi honey-yellow; base and tip of fore tibiæ, all of middle femora and tibiæ, except median dark band on each and extreme tips of hind tibiæ, honey-yellow. Wing-veins dark brown, nearly black; fore wings with two irregular transverse fuscous patches, the proximal one much darker and arising from the costal border coincident with the marginal vein, broadening slightly and becoming lighter towards anal margin and interrupted below middle by a hyaline streak (the spurious cubital nervure); the distal one arises from costal margin halfway between stigma and apex, gradually widens, and merges proximally with proximal band costad of the cubital hyaline streak which forms the anal limit of this outer band.

o. Length and expanse slightly less on the average. Striation of base of abdomen more pronounced, forming five wellmarked longitudinal carinæ united at anterior ends; antennæ 
entirely black; middle femora and tibiæ honey-yellow only at tips ; infuscation of wing lighter.

\section{Notaspis, Walker.}

\section{NotASPIS FORMICIFORMIS.}

Notaspis formiciformis, Walker, Ent. Mag. ii. p. 37. St. Vincent.

One of the most peculiar Chalcidids known. Represented by 18 specimens, one of which is labelled: "Open swampy land near sea, south end of Island : beaten from bushes, Sept. 27."

\section{Podagrion, Spinola.}

Podagrion brasiliensis, sp. $\mathrm{n}$.

․ Length of body 2 millim.; ovipositor $1 \cdot 6$ millim.; expanse 3.7 millim.; greatest width of fore wing 0.58 millim. Head and face regularly and not coarsely shagreened; pro-and mesonotum finely and closely punctate, and furnished with a few short, sparse, white, scale-like hairs; metanotum not carinate, finely and closely granulate; abdomen smooth, shining, with a few similar white hairs, which are also present on head, pleura, and coxæ; ovipositor about as long as entire body ; antennæ regularly clavate, funicle-joint 1 shorter than pedicel, 2-7 gradually increasing in width; club regularly ovate when seen from side, rather acute at tip, as long as preceding five funicle-joints together ; (in one specimen the club is indented exteriorly from drying). General colour greenish black, slightly metallic; antennal scape, pedicel, and funicle-joints $3,4,5,6$, and base of 7 bright honey-yellow ; funiclejoints 1 and 2, apical two-thirds of 7 , and all of club black or dark brown; mandibles dark brown; distal one-third of fore coxæ, all of middle coxæ, tip of hind coxæ, all of fore and middle femora, tibiæ and tarsi, base and extreme tip of hind femora, tip of hind tibiæ, and all of hind tarsi honey-yellow, the colour quite uniform, the fore femora alone somewhat darker.

Described from two female specimens from St. Vincent. The specific name is derived from the fact that $\mathrm{Mr}$. H. H. Smith has also collected the form in Brazil, several specimens occurring in a collection now in the hands of Mr. Ashmead. 


\section{Subfamily Eucharina.}

Kapala, Cameron.

\section{Kapala FURCata.}

Eucharis furcata, Fabr. Syst. Piez. p. 158.

Eucharis flabellata, Fabr. l. c.; Walker, Entomologist, i. pl. P. fig. 2.

Chirocerus furcatus, Brullé, Nat. Hist. des 'Ins., Hym. iv. p. 57l, t. 38. fig. 5.

Thoracantha furcata, Hal. Entomologist, i. pl. P. fig. 2.

Kapala fureata, Cameron, Biol. Centr.-Am., Hym. i. pl. v. fig. 17. Costa Rica, Guatemala, Panama, South America.

One male and three females of this species were taken by Mr. Smith. One of the females has an ant clasped in her jaws. This is, perhaps, significant in view of the supposed parasitism upon ants of members of this group.

\section{Orasema, Cameron.}

\section{Orasema STRAMINEIPES.}

Orasema stramineipes, Cameron, Biol. Centr.-Am., Hym. i. p. 105, pl. v. fig. 20 .

Three specimens, 1 male and 2 female, from St. Vincent.

\section{Orasema minutissima, sp. $\mathrm{n}$.}

ㅇ. Length 1.1 millim.; expanse 2.8 millim.; greatest width of fore wing 0.46 millim. Front and vertex delicately rugulose; face finely shagreened, with a curved suture each side of facial impression; mesonotum rather strongly but finely granulate; metanotum smooth, with a median longitudinal carina and a lateral somewhat oblique suture. General colour dark metallic greenish blue; scape of antennæ light straw-yellow, flagellum dusky; middle coxæ metallic, fore and hind coxæ fuscous; fore femora light brown, middle and hind femora and all tibiæ and tarsi light straw-yellow ; wing-veins very light, tegulæ yellowish.

o. Dimensions about the same, the long petiole compensating for the shorter abdomen. Face more closely shagreened, curved sutures nearly obsolete; mesonotum more strongly granulate; metanotum delicately shagreened, central carina very faint. Flagellum of antenna darker than in female; all legs stramineous except coxæ, which are metallic at base and yellowish at tip.

Described from 17 females, 5 males. St. Vincent. 


\section{Chalcura, Kirby.}

Chalcura americhana, sp. $n$.

ㅇ. Length $2 \cdot 4$ millim.; expanse $5 \cdot 2$ millim. Face nearly smooth below and at margins of eyes, with very faint interrupted striæ and very sparse punctures; several rather strong longitudinal grooves begin at insertion of antennæ and extend parallel with antennal groove nearly to occipital margin ; disk of mesoscutum coarsely reticulate, the cells irregularly pentagonal or hexagonal, lengthening out obliquely on the parapsidal sutures, and becoming longitudinally greatly lengthened on the mesoscutellum, axillæ, pleura, and metanotum; petiole finely longitudinally aciculate; abdomen smonth, shining. General colour shining black; all legs except coxæ nearly white, faintly yellowish, almost translucent; coxæ brown; antennal scape, pedicel, and the plainly 3-jointed club bright honey-yellow; the six funiclejoints brown, joints 5 and 6 somewhat lighter than the first four. Wings hyaline; fore wings absolutely devoid of marginal cilia; wing-veins faintly coloured except stigma, which is brown; fore wing below stigma with a faint, irregularly rounded, infuscated patch.

Described from one female specimen. St. Vincent.

\section{Subfamily Perilampinæ.}

\section{Perilampus, Latr.}

Perilampus politifrons, sp. n.

б. Length $1 \cdot 7$ millim.; expanse 3 millim. Face smooth, shining; margin of antennal groove rounded, no carina; facial grooves below insertion of antennæ well marked; transverse furrow between the facial grooves also pronounced; vertex slightly and sparsely punctate; occiput very plainly transversely striate, the striations parallel with the curve of the occipital margin ; antennæ short, clavate, slightly hairy ; dorsum of thorax coarsely, thickly, but shallowly punctate, but one row of these punctures showing in middle of pronotum, each depression with a slight central elevation, from which arises a short white bair: axillæ delicately longitudinally striate; outer border of parapsidal suture smooth ; tip of mesoscutum not indented ; metascutellum with a well-marked median longitudinal carina; nucha plainly transversely striate; all pleura smooth; head and thorax with 
sparse, short, white pubescence ; all femora and tibiæ somewhat pubescent; abdomen smooth, shining. General colour black; antennal flagellum light brown; trochantero-femoral and femorotibial articulations honey-yellow ; front and middle tibiæ honeyyellow at either extremity; hind femora entirely honey-yellow; all tarsi whitish; submarginal vein pale to the point where upward bend begins, thence brown; other veins of fore wing brown; wing-membrane perfectly hyaline.

Described from two male specimens, St. Vincent. Differs from other described species principally in the caputal characters.

\section{Subfamily Enctrine.}

\section{Cerchysius, Westw.}

Syn. Aseirba, Cameron.

This genus, erected by Westwood in 1832 ('London and Edinburgh Philosophical Magazine and Journal of Science,' vol. i. July-December, 1832, p. 127) with very brief characters, for Encyrtus urocerus, Dalm., is rejected by Mayr, who retains urocerus in the genus Encyrtus. Thomson retains Cerchysius with a somewhat indefinite diagnosis; and as two species are found in the St. Vincent material which possess in part the characters of $C$. urocerus, it is deemed best to use the generic name Cerchysius, especially as the terebral characters alone separate the forms from all other members of the true genus Encyrtus. The characters which may be regarded as of generic value and in which the following species agree are as follows:-

ㅇ. Head subsemiglobose; eyes widely separated; ocelli forming a right-angled triangle; antennæ inserted below middle of face, scape somewhat widened below and reaching to vertex; flagellum long, slender, and cylindrical, club very slightly enlarged. Mesoscutum and scutellum somewhat flattened, together somewhat tectiform, the scuto-scutellar furrow forming the ridge; scapulæ meeting at apex. Abdomen triangular; terebra exserted for at least half the length of abdomen proper. Legs rather longer than normal, resembling in this respect those of Leptomastix; middle tibial spur not quite so long as first tarsal joint. Wings with short marginal, postmarginal, and stigmal veins, the latter subequal in length; a narrow, oblique, hairless streak extending from costal margin at stigmal vein to near base of wing on anal margin.

$\delta$. Differs from female mainly in the funicle-joints of the 
antennæ, which are plano-convex dorsally and slightly concave ventrally, subequal in length, each about three times as long as broad, and each furnished with two whorls of long hair. The spur of middle tibia rather longer than the corresponding first tarsal joint.

Cameron's genus Aseirba, placed by this author in the Eupelmince (Biol. Centrali-Americana, Hymenopt., i. p. 127, pl. vi. fig. 13), seems, both from description and figure, to be a synonym of Cerchysius.

\section{Cerchysius terebratus, sp. $\mathrm{n}$.}

․ Length (to tip of terebra) 2 millim.; expanse $2 \cdot 7$ millim. Antennal scape nearly cylindrical, only very slightly widened below. Head and mesoscutum glistening, very finely shagreened, with sparse larger punctures and short sparse pubescence; mesoscutellum deeply and closely, though finely shagreened, opaque; pleura and abdomen smooth, glistening; terebra a little over half the length of the abdomen, pubescent, especially toward tip. General colour honey-yellow, legs somewhat lighter than body; mandibles brown; antennal scape black at base and with a dark longitudinal dorsal streak; pedicel dark at base and with apical half light honey-yellow; all funicle-joints dark brown, except joint 2, which is light honey-yellow, with the exception of a brownish apex, club light honey-yellow; head sometimes slightly infuscated ; sides of metascutellum and base of abdomen fuscous; terebral sheaths black except at base; pygidium dusky at tip; wing-veins dark.

o. Length 1.1 millim.; expanse 2.7 millim. Antennal scape entirely black ; mesoscutellum with a central dusky patch ; metascutum dusky; metascutellum honey-yellow; dorsal surface of abdomen infuscated. Otherwise agrees with female.

Described from two females and one male.

\section{Cerchysids pulchricornis, sp. n.}

ㅇ. Length (to tip of terebra) 2 millim.; expanse $3 \cdot 3$ millim. Scape considerably widened. Head and mesonotum opaque, densely and finely punctate, and clothed (particularly mesoscutum) with rather close appressed pubescence. General colour rather bright honey-yellow; antennæ black, variegated with silvery white as follows: a narrow band near base of scape, a broader band at tip, apical half of pedicel, all of funicle-joints 2 
and 6 and the club; terebral sheaths and tip of pygidium below black, as in $C$. terebratus.

Described from one female specimen.

\section{Enasids, Walker.}

This genus, proposed by Walker in 1846 for his Encyrtus hyettus, has never been sufficiently described, and is not recorded in any of the nomenclators. I have little or no doubt, however, of the identity of a peculiar form contained in the collection with $E$. hyettus, and have therefore drawn up the following full generic description :-

ㅇ. Resembles in general appearance the female of Bothriothorax. Antennæ strongly clavate; scape rather short, reaching only to middle of eye, with a very broad, leaf-like, inferior expansion; pedicel, funicle, and club together forming a regular ovate, clavate mass, slightly flattened towards tip and rapidly widening from the very narrow base of the pedicel to the articulation of the first and second joints of the club, thence gradually rounding off; each of the six funicle-joints much wider than long : club nearly as long as entire funicle. Antennal grooves deep, converging; eyes very large, hairy, mainly lateral ; genal sulcus distinct, complete; front rather narrow above, widening rapidly below ; ocelli forming a nearly equilateral triangle, lateral ocelli touching border of eyes; entire head except occiput and facial depression covered closely with large thimble-like depressions, each with a very minute central piliferous tubercle; occipital ridge very acute. Pronotum not visible in the specimen at hand; mesoscutum short; mesoscutellum large, long, acutely margined, rounded posteriorly, having a fine, sharp, longitudinal groove for about one fifth its length at base; scapular sutures absent, represented only by very faint depressed lines, visible only in a strong light, but which can then be traced with difficulty and indicate that the scapulæ are well separated at tips. Abdomen short, triangular; terebra not extruded. Submarginal vein of fore wings short; marginal very short, almost wanting; stigmal rather long, slender, very slightly curved, extending down at an angle of about 40 degrees with the postmarginal, club very small ; postmarginal somewhat longer than stigmal. Legs of the normal Encyrtine type, rather short; front tarsi especially short.

đ. Differs from female in following particulars:-Antennæ more hairy and not so strongly clavate; pedicel plainly distinct 
from funicle, and joints of funicle are well separated, giving a serrate appearance to the margin ; first funicle-joint very narrow ; joint 2 suddenly wider; widest point of flagellum at about joint 5 of funicle; club short, not longer than the three preceding funicle-joints together, obliquely truncate at tip, appearing acute from side and rounded from above. Vertex broader than in female. Pronotum narrow, entire. (This is probably also the case with the female, in which it cannot be seen.) Abdomen very short, not longer than mesoscutellum in specimens at hand, in which, however, it is doubtless abnormally short through drying.

\section{Anasius hyettus.}

Encyrtus hyettus, Walker, Ann. Mag. Nat. Hist. xvii. (1846) p. 181. St. Vincent.

ㅇ. Length 1.6 millim.; expanse 3.9 millim.; width of body at tegulæ 07 millim. Antennal scape closely pubescent above, but not on leaf-like expansion; front also pubescent. Head with large thimble-like punctures; mesonotum very faintly shagreened, nearly smooth; abdomen smooth, shining; colour uniform black, with bluish metallic reflections on dorsum of thorax; all tarsi honey-yellow, final joint black; middle tibial spur dark brown, nearly black ; fore wings dark fuscous, veins nearly black; hind margin also black; hind wings hyaline, veins dark brown.

o. Length varying from 0.88 millim. to 1.26 millim.; expanse varying from 2 millim. to 2.9 millim. Closely resembles the female except in the distinctions pointed out in generic diagnosis, but the metallic reflections are not so strong, and the fore wings are only faintly suffused with fuscous, while the veins are brown.

Redescribed from one female and four male specimens; one labelled "May," another "South end," and the rest with the customary label.

\section{HABROLEPOIDEA, gen. nov.}

․ Antennæ 11-jointed; scape moderately long, with a slight leaf-like expansion below; pedicel stout, nearly as broad as long; the 6-jointed funicle short, compressed, all joints broader than long, increasing slightly in width from 1 to 6 , and also slightly in length, joint 6 being longest; club flattened, oval, widest at tip of first joint, considerably wider than sixth funiclejoint and as long as entire funicle. Head flattened above, long

LINN. JOURN.-ZOOLOGY, VOL. XXV. 
between the sharp occipital ridge and the rounded frontal ridge, appearing triangular from side, the frontal ridge forming the vertex of an obtuse-angled triangle, of which the facial side is a trifle longer than the vertical, while the occipital side is much the longest and is slightly convex ; eyes large and almost entirely lateral, the ocellar space broad, and the ocelli at the angle of a slightly obtuse-angled triangle; genal sulcus distinct but not complete, reaching neither border of eye nor border of mouth. Pronotum very short, completely hidden by occipital margin of head in the only specimen at hand. Scapulæ just meeting at tip ; mesoscutellum triangular, acute at tip, with two depressions each side near tip, which may possibly be the result of shrivelling. Abdomen subtriangular, flattened, terebra just visible. Marginal vein of fore wings present, but shorter than stigmal; postmarginal present, nearly as long as stigmal; stigmal rather long, straight, slightly curved at tip, and forming a very acute angle with the postmarginal.

Habrolepoidea glauca, sp. n.

ㅇ. Length 0.93 millim.; expanse 2.2 millim.; greatest width of fore wing 0.35 millim. Head smooth, shining, with a very faint striation and a few faint and very sparse fine punctures, a row of small punctures at border of eyes. Mesonotum lustrous, very faintly and finely reticulate. General colour dark brown, black, or metallic; head with steel-blue reflections, mesonotum with golden-green reflections; abdomen black ; antennæ honeyyellow, darker at articulations; all legs honey-yellow, coxæ black. Wings hyaline.

Described from one female specimen.

Homalopoda, gen. nov.

ㅇ. Antennæ 9-jointed; scape reaching to vertex, cylindrical, slender; pedicel slender, subcylindrical, nearly twice as long as broad; the funicle-joints slender, cylindrical, subequal in length, each longer than pedicel; club as long as the three preceding funicle-joints together, very elongate-ovate, slightly wider than funicle or somewhat flattened, in which case it is considerably wider. Head with long flattened face and deep antennal grooves converging towards vertex; genal sulcus distinct, from eye to mouth; vertex and dorsal surface of eyes flat, making the head appear triangular from the side; eyes rather 
close, not large and mainly dorsal, ocelli forming an acute-angled triangle; occipital ridge rounded. Pronotum sharply incised in middle; scapulæ narrow towards tips, barely meeting; mesoscutellum declivous, subtriangular, rather rounded at tip, and having a sparse tuft of bristles; metascutum very short. Fore and middle legs normal, rather short; hind femora somewhat enlarged, convex on the outer surface, plane on the inner; hind tibiæ flattened laterally. Wings fuscous, with oblique hairless line below stigma and with several hyaline spots; submarginal vein short, reaching margin before one half the wing-length; marginal short, obscured by brown bristles, but longer than the short stigmal, which obliques into the wing-surface at an acute angle with the post-costa; postmarginal wanting. Abdomen as long as thorax, concave above, subtriangular, although somewhat rounded towards apex; terebra exserted to about one sixth the length of the abdomen.

This genus is one of the intermediate forms between the Encyrtince and the Eupelmince, and presents in fact quite as many Eupelmine as Encyrtine characters.

\section{Homalopoda CRISTata, sp. n.}

ㅇ. Length varying from $1 \cdot 11$ millim. to $1 \cdot 86$ millim.; expanse varying from $2 \cdot 26$ millim. to 2.79 millim. Face lustrous, very faintly sbagreened; vertex deeply, closely, and finely shagreened; mesoscutum as with face; mesoscutellum as with vertex; abdomen smooth, shining. From the occipital ridge near the eyes arise two slender blunt modified hairs or scales, plainly flattened antero-posteriorly, and which may resemble the "schmale.... abgerundete Lamellen," which occupy a similar position in the European Habrolepis Dalmanni, Westw. Mesoscutellum with a sparse tuft of bristles near tip. Wings fuscous, hyaline at base and with six hyaline spots, three on either border of the wing, and all touching wing-border except the proximal caudal one, which is separated from border by a continuation of the fuscous; the two distal ones crescent-shaped and the others roundish, the proximal one on the costal margin considerably smaller than the others and situated halfway between beginning of fuscous shading and stigmal vein; middle costal hyaline spot beginning just at stigmal vein, the middle caudal spot being just opposite on caudal wing-border; marginal vein with many dark bristles, making a distinct brown patch at that point. General colour 
metallic greenish blue; dorsal surface of head golden-green; mesoscutellum copper-coloured; antennæ very dark brown, scape slightly metallic ; all legs black or slightly metallic, middle and hind tarsi dirty white with terminal joint brown, fore tarsi light brown.

Described from four female specimens, two labelled "Leeward side." One of these specimens lacks the apical pair of hyaline spots on the wing, but should not be separated.

\section{Comys, Förster.}

COMYS BICOLOR.

Comys bicolor, Howard, Report of the Entomologist, Annual Report Department of Agriculture, 1880, p. 362.

Parasitic on the cosmopolitan Lecanium hesperidum and other congeneric species in the United States.

Two female specimens, St. Vincent.

Leptomastix, Förster.

\section{LEPTOMASTIX DACTYLOPII.}

Leptomastix dactylopii, Howard, Bulletin 5, Division of Entomology, U.S. Department of Agriculture (Washington, 1885), pp. 23, 24.

District of Columbia. One male, St. Vincent.

\section{Copidosoma, Ratzeburg.}

\section{Copidosoma dIVERSICORNIS, sp. $\mathrm{n}$.}

․ Length $1 \cdot 4$ millim.; expanse $2 \cdot 6$ millim.; greatest width of fore wing 0.37 millim. Antennal club flattened dorso-ventrally, rather longer than funicle-joints 5 and 6 together, and but slightly wider than joint 6 , slightly rounded at apex ; first funicle-joint nearly twice as long as pedicel; joint 2 of funicle slightly longer than pedicel; joints $2,3,4,5$, and 6 subequal in length and width. Punctation of head and thorax as usual. Marginal vein of fore wings as long as stigmal. Ovipositor not extruded. Colour black, without metallic reflections ; antennal scape brown, with a whitish band at tip ; pedicel, joints $1,3,4,5$, and 6 of funicle, and base of club black; joint 2 of funicle and rest of club silvery-white; tegulæ honey-yellow at tips, otherwise black; all coxæ black; fore and middle femora black at base, honeyyellow beyond; hind femora black nearly to the honey-yellow tip ; all tibiæ and tarsi very light honey-yellow, the underside of the middle tarsi appearing brownish from the numerous brown spines.

Described from two male specimens (216 and 207). 


\section{Encrrtus, Dalm.}

Table of Species.

All funicle-joints of antennæ wider than long ....

All funicle-joints not wider than long.

Club very broad, at least three times as wide as preceding funicle-joint $\ldots \ldots \ldots \ldots \ldots$.

Club not especially broad, but slightly broader than preceding funicle-joint.

Head and mesoscutum very hairy......... E. hirtus, sp. n. Not especially hairy.

Antennæ uniformly honey-yellow.

Wings partly infuscated............ E. nitidus, sp. n.

Wings hyaline................ E. quadricolor, sp.n.

Antennæ black, yellow at tip $\ldots \ldots \ldots \ldots$ E. flaviclavus, sp. n.

Antennæ brown ................ E. tiliaris, Dalm.

Encrrtus crassus, sp. n.

9. Length 1.37 millim.; expanse 2.8 millim. Belongs to the same group as E. inquisitor, How. (Ann. Rept. Dept. Agr. 1880, p. 67, pl. xxiv. fig. 1), and the European E. clavellatus, Dalm. Body short and stout. Antennæ with the scape slightly widened beneath; joints 1-6 of the funicle gradually increasing in width, all wider than long; pedicel $2 \frac{1}{2}$ times longer than first funicle-joint and somewhat wider; club broad, flattened, subcircular, as long as three preceding funicle-joints together. Front wide, ocelli forming an obtuse-angled triangle. Head and mesonotum delicately shagreened. Marginal vein of fore wings absent. General colour black, moderately lustrous, without metallic reflections; antennal club with whitish pile at tip; front and hind tarsi brown; middle tarsi and middle tibial spur light honey-yellow, with claws only dark. Wings hyaline, veins brown; a trace of a radial vein extends from tip of stigmal club in a curved direction, reaching costal margin at a point nearly halfway from stigmal club to tip of wing.

Described from one female specimen.

EnCYRTUS QUADRICOLOR, sp. $\mathrm{n}$.

$\widehat{0}$. Length $1 \cdot 16$ millim.; expanse $2 \cdot 6 \boldsymbol{t}$ millim. Antennæ inserted halfway between middle of face and mouth; scape subcylindrical, not broadened, not long; pedicel twice as long as broad; all six funicle-joints of equal length with pedicel, but increasing slightly in width from 1 to 6 ; club a little longer than the two preceding funicle-joints together, oval, slightly flattened, 
broader than joint 6 ; flagellum with very short pubescence. Front very convex, almost angulate in middle; facial depression very marked; genal sulcus complete, but very indistinct; eyes sparsely hairy; vertex not narrow, ocelli forming a slightly obtuse-angled triangle; head with a very fine reticulated sculpture and with a single row of fine punctures around the margin of the eyes; occipital ridge extremely sharp. Mesoscutum very finely but closely and deeply shagreened and furnished with fine sparse pubescence, opaque; mesoscutellum highly lustrous, nearly smooth, slightly shagreened near base. Marginal, postmarginal, and stigmal veins of the fore wings all nearly equal in length. General colour bright honey-yellow; antennæ brown, darkest on upper surface of scape, pedicel, and club; head and pronotum uniform black, with greenish-metallic lustre; mesoscutum, except lateral margins, a brilliant peacock-blue ; mesoscutellum goldengreen; abdomen dark, with a golden-green lustre; hind tarsi dusky, nearly black.

Described from one male specimen.

Encyrtus nitidus, sp. n.

ㅇ. Length $1 \cdot 4$ millim.; expanse $2 \cdot 6$ millim. Resembles $E$. fuscipennis, Dalm., perhaps more closely than any other species. Scape arising halfway between bend of face and mouth, subcylindrical, not broadened, very short, only five times as long as thick; pedicel three times as long as thick and twice as long as the somewhat narrower first funicle-joint; funicle-joints increasing very slightly in length and more in width from 1 to 6 ; club flattened, oval, as long as the two preceding funicle-joints together. Front narrow between the eyes; ocelli forming an acute-angled triangle; front and vertex very finely shagreened, with four rows of punctures ; cheeks smooth ; genal sulcus absent. Mesoscutum lustrous, very faintly shagreened, with sparse, short, whitish pubescence; mesoscutellum densely punctulate at base, then closely striate to tip, which is smooth and shining. Abdomen flattened dorso-ventrally, acuminate, as long as head and thorax together; ovipositor slightly extruded. Stigmal vein given off at juncture of submarginal and costa, short, postmarginal of equal length; a broad, oblique, hairless line below stigma, across which passes obliquely towards costa a single row of minute hairs. General colour black, with metallic-greenish or bluish reflections; antennæ honey-yellow, flagellum a little darker than scape; front legs, including coxæ, light honey-yellow; 
middle coxæ metallic, yellowish at tip ; femora, tibiæ, tibial spur, and tarsi honey-yellow, femora brownish at middle; hind coxæ honey-yellow, slightly darker at base, tibiæ and tarsi honey-yellow, femora dark except at tips. Wings hyaline; fore wings with a dusky patch of an irregular trapezoidal form, beginning in the middle opposite stigma and extending to tip, gradually widening, occupying at widest portion of the wing about one-third of the wing-width.

Described from five female specimens.

\section{Enctrtus argentipes, sp. n.}

ㅇ. Length 0.7 millim.; expanse 1.6 millim. Agrees in some structural details with $E$. brevicornis, Dalm., but differs in having the antennal scape but slightly broadened, in the shape of the head, and in coloration. The sole specimen is badly mounted and this description is necessarily incomplete. Antennæ inserted a little below middle of face; scape short, very slightly widened below in middle, pedicel very short; funicle conical, short, not longer than club, the joints widening rapidly; club as long as funicle, obliquely flattened, nearly circular. Facial impression horseshoe-shaped, the central ridge rounded but pronounced; vertex flattened, narrow, the ocelli forming an acute-angled triangle, the head appearing rather triangular from side, somewhat as in Habrolepis. Marginal vein of fore wings short, postmarginal present, as long as stigmal, the latter forming a narrow angle with the postmarginal. Head faintly shagreened; mesonotum appearing smooth and glistening (the sculpturing, if any, obscured by mounting medium). Colour shining black; antennal scape silvery-white at tip, funicle silvery-white, with dense short white pubescence, club black; all coxæ black; all femora, tibiæ, and tarsi silvery-white, the femora with a black band at middle and the tibiæ with a black band between middle and proximal end. Wings hyaline.

Described from one female specimen. This species probably belongs to a new genus; but, without specimens from which all the characters can be studied, it seems inadvisable to establish one.

Enctrtus Hirtus, sp. n.

․ Length 0.9 millim.; expanse 2 millim.; greatest width of fore wing 0.36 millim. Forms a new type in the genus, and will doubtless eventually be separated generically. Antennal scape short, stout, not widened below; pedicel very narrow at proximal end, two and one half times longer than its width at distal end; 
first funicle-joint one half as long as pedicel and nearly as broad as long; joints 2 to 6 subequal in length, but increasing somewhat in width, joint 6 being once and half broader than long; club as long as three preceding funicle-joints together, oval, its sutures distinct and its first joint slightly broader than joint 6 of funicle, making the whole flagellum slightly clavate. Head somewhat triangular when seen from side, the facial angle below the middle; face and vertex hairy, delicately shagreened, with a few sparse larger punctures; eyes hairy. Mesoscutum finely granulate, well covered with short black hairs; mesoscutellum smooth, shining, almost hairless; abdomen short, smooth, circular in outline; legs short and stout; marginal, stigmal, and postmarginal veins of fore wings subequal in length. Colour : head and thorax to scuto-scutellar furrow of mesonotum dull dark metallic green; mesoscutellum and abdomen bright metallic green, with golden reflections; all legs and antennæ honey-yellow.

o. Rather smaller than female, with which it almost exactly agrees. Antennæ with funicle-joints subequal in length, well separated, and each with a double whorl of long hairs. Abdomen subtriangular.

Described from two females and one male.

Encyrtus flaviclates, sp. $n$.

ㅇ. Length $1 \cdot 1$ millim.; expanse 2.7 millim. Antennal scape moderately long, slender, not widened; pedicel short, its breadth at tip equalling its length; funicle and club somewhat flattened laterally; joints $1,2,3,4$, and 5 of funicle subequal in length and width, each longer than broad and a little longer than pedicel; joint 6 shorter; club oval, as long as funicle-joints 5 and 6 together; face and vertex smooth, with a few sparse punctures; mesoscutum delicately transversely shagreened; mesoscutellum with aciculate longitudinal punctation; abdomen cordate, shorter than thorax ; marginal and postmarginal veins of fore wing each slightly longer than stigmal, the latter forming a very slight angle with postmarginal. Colour: head and pleura metallic purple; rest of body metallic green, mesoscutellum with a coppery lustre; antennal scape honey-yellow; funicle and base of club very dark brown; rest of club bright orange-yellow; all legs honey-yellow.

Described from one female specimen. St. Vincent. 


\section{Enctrtus tiliaris.}

Encyrtus tiliaris, Dalm. Vet. Ac. H. 1820, p. 174 (47); Nees, Hym. Ichn. aff. Monogr. 1834, p. 235; Mayr, Die Eur. Encyrtiden, Verh. d. zool.-bot. Ges. Wien, 1875, p. 722.

Encyrtus coniferæ, Walk. Ent. Mag. iv. 1837, p. 461.

Encyrtus cupratus, Först; ? Mayr, loc. cit.

Two females and one male of what seems to be this European species. St. Vincent.

\section{Subfamily ApHeLININ e. \\ Coccophagus, Westwood.}

\section{Coccophagus Lecanir.}

Platygaster Lecanii, Fitch, Fifth Report on the Insects of New York, p. 25.

Coccophagus Lecanii, E.A. Smith, 'American Naturalist,' 1878, p. 661 ; Seventh Report, State Entomologist of Illinois (1878), p. 130.

Coccophagus Lecanii (Fitch), Howard, Report of Entomologist, Annual Report U.S. Department Agriculture, 1880, pp. 357, 358.

Two female specimens. St. Vincent.

In the United States this insect is parasitic upon Lecanium quercitronis, Fitch (N. Y.), Pulvinaria innumerabilis, Rathvon (Ills. and D. C.), and Lecanium hesperidum, Linn. (D. C. and Cal.). The last-named is a cosmopolitan species and undoubtedly occurs on the island of St. Vincent, since it has been found on Jamaica and Montserrat.

\section{Encarsia, Förster.}

\section{Encarsia flaticlata, sp. n.}

ㅇ. Length 1 millim.; expanse 1.8 millim. Antennal flagellum slightly clavate when seen from side; funicle-joints subequal in length and increasing slightly in breadth from 1 to 4 , joint 4 nearly as broad as long; club oval; seen from above, the funicle is parallel-sided and the club is much narrower through lateral flattening; terebra exserted for one-third length of abdomen; abdomen with parallel sides to an abruptly conical tip. General colour honey-yellow; scape of antennæ darker, pedicel and funicle black, club light yellow; lateral borders of abdomen brown; a dark brown, nearly black, patch at lateral anal angles of abdomen; venter of abdomen with brownish shades; wings hyaline, veins light.

Described from one female specimen. St. Vincent. 


\section{Subfamily Pirenine.}

Herbertia *, gen. nov.

ㅇ․ Antennæ 10-jointed, inserted just above clypeus, short, clavate; scape short, slender, not reaching to middle of face; funicle-joints subequal in length, but increasing rapidly in width from 1 to 5 ; club short, compact, acute at tip, flattened from side; face below eyes short, genæ straight; facial depression deep and broad, occupying more than half the width of face between eyes, its margin rounded; eyes hairy; ocelli large, placed at the angles of a right-angled triangle; occipital margin rounded. Parapsidal furrows of mesoscutum sharp and complete, continuous with axillar furrows; axillæ widely separated; mesoscutum and scutellum rather flat, in the same longitudinal plane, scutellum at tip and metanotum abruptly declivous; submarginal vein of fore wing reaching costa at about one third the wing-length, marginal a little longer than submarginal; postmarginal long, shading off almost imperceptibly, apparently somewhat more than one third the length of marginal; stigmal short, very oblique, about one third the length of postmarginal, club not pronounced, uncus rather long, forming a little more than a right angle with a shaft of stigmal; metanotum nearly rectangular, a little narrower behind, the hinder angles sharp and a little extended; hind coxa with a pronounced dorsal tooth above near tip as in some Chalcidince. Abdomen ovate, thick dorsoventrally; second tergite occupying about half of the dorsum of abdomen; pygidium rather large, projecting well beyond the terminal ventral segments (urites); ovipositor generally extruded.

$0^{*}$. Very similar to female. Antennal flagellum shorter than in female, club equally flattened, but broader and rounded at tip; coxal projection less pronounced; metanotum more contracted behind. Abdomen ovate, slightly truncate at tip, not flattened, second tergite occupying less than half the dorsum.

Of the described Pirenine genera, this resembles most closely Henicetrus, Thomson, which I know, however, from the very brief description in 'Skandinaviens Hymenoptera,' iv. p. 190.

Herbertia lucens, sp. n.

ㅇ. Length 1.5 millim.; expanse 2.5 millim. Antennal scape straight, slender, cylindrical; pedicel twice as long as first funicle-

* From Herbert, the first name of Mr. H. H. Smith. 
joint, but slenderer; entire head, pro- and mesonotum closely shagreened; metanotum smooth, central carina well marked, alæ marked by evident carinæ; second tergite of abdomen perfectly smooth, glistening, other tergites dull, very faintly transversely striate. General colour metallic green, with bright golden reflections where punctation is lacking, as on mesopleura and second tergite; scape and pedicel of antennæ metallic, funicle and club dull brown with very short close pubescence; tegulæ dark brown; all coxæ and femora metallic; all tibiæ and tarsi yellowish white; abdomen beyond second segment dull purplish black, ovipositor light brown; wings hyaline, veins brown. Head, pronotum, mesonotum, and abdomen beyond second segment with short whitish pubescence.

$\delta$. Resembles female, except that flagellum and club of antennæ are nearly black and the veins of fore wing are dark brown.

Described from nine female and five male specimens. St. Vincent.

\section{Erotolepsia, gen. nov.}

․ Antennæ 11-jointed (club 3, funicle 6, pedicel and scape), inserted at clypeal margin ; scape long, slender, reaching nearly to anterior ocellus; flagellum somewhat longer than scape, subclavate; pedicel long, obconical, straight, as long as first three funicle-joints ; first funicle-joint as broad as long, others subequal in length and increasing very gradually in width; club bluntly pointed; facial depression deep, its border sharp and slightly elevated; eyes naked; ocelli of moderate size, at angles of an obtuse-angled triangle, the lateral ones tangent to the occipital margin, which is slightly rounded. Parapsidal sutures indicated only at anterior margin of mesoscutum; mesoscutum rather flat; mesoscutellum slightly elevated, not abruptly declivous; submarginal vein of fore wing reaching costa at nearly one half the wing-length, marginal two-thirds as long as submarginal; postmarginal and stigmal subequal in length, the latter a trifle the longer, about one fourth as long as marginal ; stigmal curved, club very slight, uncus very short; metanotum rounded, not carinate, but bears at the middle of its anterior border a stout, sharp, spine-like process, alæ separated by delicate sutures; hind coxæ not toothed. Abdomen ovate, very acute at tip, flattened above, well rounded beneath; second tergite excavated anteriorly and occupying nearly the whole dorsum of abdomen; pygidium as in Herbertia; ovipositor not exserted. 
đ. Greatly resembles female; pedicel of antennæ not quite so long in proportion to the funicle-joints which follow; spinelike process of metanotum represented by a slight elevation only; club of stigmal vein of fore wings more pronounced than in female; abdomen bluntly rounded at tip; genital organs, when exserted, fully two thirds the length of abdomen.

The habitus of this genus is much like that of the preceding, in spite of the marked differences in structural detail. The head in all of the 18 specimens of both genera is thrown forward, the labium brought close to the fore coxæ, the occiput entirely exposed, and the rather prominent and well-rounded pronotum brought strongly into view.

Erotolepsia compacta, sp. n.

ㅇ. Length 1.8 millim.; expanse 3 millim. Head, pronotum, and mesonotum finely shagreened, mesonotum with a few sparse round punctures, slightly glistening; pleura smooth, except mesepimeron and propleuron, which are faintly granulate; metascutellum very finely granulate; abdoinen nearly smooth, shining; the long second abdominal tergite with two subparallel laterodorsal furrows extending from the cephalic nearly to the caudal end of the segment; between these furrows the cephalic end of the tergite is delicately longitudinally striate, the striations arising from the upturned cephalic border and fading away gradually about the middle of the segment, the lateral ones being a little longer than the central ones; ventral surface of abdomen delicately longitudinally striate, except at lateral border; head, mesonotum, and tip of abdomen with sparse whitish pubescence, of which there is also quite a pronounced fringe on outer border of hind coxæ; metanotal fimbria well marked. General colour dull black ; antennal scape and pedicel honey-yellow, the pedicel shaded with brown above at base; all legs, except coxæ, uniform honey-yellow, tip of hind femora a little darker; fore wings slightly infuscated, the infuscation deeper in middle, veins dark brown.

o. Somewhat smaller than female, which it resembles, however, in all other respects except usual sexual differences and those pointed out in generic diagnosis.

Described from two female and two male specimens. St. Vincent. 


\section{Subfamily Elasmina.}

\section{Elasmus, Westw.}

Table of Species.

Head smooth, with very small sparse punctures.. E. levifrons, sp. n.

Head with irregular depressions $\ldots \ldots \ldots \ldots \ldots$ E. rugosus, sp. n.

Head with sparse large punctures........... E. punctatulus, sp. n.

Head with close large thimble-like punctures.

Head yellow, with round metallic frontal spot centred by anterior ocellus $\ldots \ldots \ldots \ldots$ E. maculatus, sp. n.

Head all yellow ................... E. flavus, sp. n.

Head metallic.

Body nearly all yellow $\ldots \ldots \ldots \ldots \ldots \ldots$ E. helvus, sp. n.

Abdomen only yellow............... E. flaviventris, sp. n,

Body metallic.

Hind coxæ with apical half yellow ..... E. Smithii, sp. n.

Hind coxæ all metallic ............. E. punctatus, sp. n.

Elasmus levifrons, sp. n.

ㅇ. Length $2 \cdot 2$ millim.; expanse $3 \cdot 4$ millim.; greatest width of fore wing 0.39 millim. Face and vertex smooth, well rounded, with small sparse round punctures; pronotum and mesoscutum regularly scaly with appressed hairs; mesoscutellum very finely granulate, but shining; abdomen very faintly transversely striate, longer than head and thorax together; all pleura and hind coxæ bairless, shining, irregularly shagreened, the coxæ more coarsely than the pleura; middle and hind femora somewhat obliquely longitudinally shagreened, middle femora with sparse appressed hairs. Funicle-joints 1, 2, 3 of the antennæ subequal in length and width, all wider and longer than pedicel, but somewhat shorter than club, which is slightly flattened and acuminate; first tarsal joint of fore legs about half as long as tibia; corresponding joint of middle and hind legs as long as tibia. Two dark brown subparallel longitudinal raised lines on dorsum of fore and middle tibiæ; a series of five or six irregular longitudinal closed cells formed by similar dark brown lines on hind tibiæ*; middle tibial spur about $\frac{1}{4}$ as long as first tarsal joint. General colour dark metallic greenish-blue; antennæ dark brown, scape yellowish beneath; minute tip of scutellum yellowish white;

* These dark brown or black raised lines, the peculiar arrangement of which on the hind tibiæ affords such a good character in this genus, are, when examined under a high power, seen to be rows of acute appressed spines situated so closely together that their bases touch. 
tegulæ yellowish white; distal half of fore coxæ and tip of middle coxæ, all trochanters, all of fore femora, except brown shade on proximal dorsal half, tips of middle and hind femora, all tibiæ and tarsi dirty white or yellowish white; bristles of all tibiæ and tarsi dark brown. Wings hyaline; veins light brown, faint; cilia of disk of wing very delicate; stigmal represented by a mere point.

o . Length $1 \cdot 2$ millim.; expanse $2 \cdot 6$ millim.; greatest width of fore wing 0.35 millim. Differs only in the ordinary sexual differences of the genus; antennal branches subequal in length and reaching to middle of antennal club; the long hairs on branches dirty white.

Described from twelve female and eight male specimens.

\section{Elasmus Rugosus, sp. n.}

ㅇ. The single specimen of this species in the collection lacks antennæ and abdomen, but seems from general appearance to be a female. Its length can only be surmised, but the insect is apparently similar to the preceding in size. Expanse 2.6 millim.; greatest width of fore wing 0.34 millim. Differs from $E$. levifrons as follows:-Face and vertex closely covered with large irregular punctures; mesoscutellum smooth. No scutellar spot; the raised dark brown lines on dorsum of hind tibiæ forming much longer closed cells than in $E$. levifrons, the two largest occupying almost its entire length, the proximal of the two being considerably longer than the distal one ; fore legs entirely dirty yellowish white; middle femora brown, whitish at tips; basal half of hind femora whitish, apical half brown; distal tip of hind coxæ whitish; wing-veins dark brown, stigmal not distinct, discal cilia closer and larger; disk slightly infuscated.

Described from one female (?) specimen.

Elasmus punctatulus, sp. n.

o. Length $1 \cdot 2$ millim.; expanse $3 \cdot 1$ millim.; greatest width of fore wing 0.39 millim. Differs from E. levifrons as follows :Face and vertex with rather sparse round punctures, twice as large as in $E$. levifrons, and yet each with a definite smooth expanse about it. Scutellar spot orange-yellow, thin, crescent-shaped, with a plain triangular membranous transparent appendix or postscutellum; the raised dark brown lines on dorsum of hind tibiæ forming two subequal cells in the middle with a half cell at either end. Antennal scape entirely dirty white; clypeal margin of face yellowish; all fore legs, except base of coxæ, 
yellowish white; middle and hind femora with merely a median band of slightly metallic dark brown.

Described from one male specimen.

Elasmus maculatus, sp. n.

ㅇ. Length $2 \cdot 2$ millim.; expanse 3.7 millim.; greatest width of fore wing 0.44 millim. Face and head with close, deep, rather large round punctures, almost thimble-like ; first tarsal joint of fore legs one third as long as tibia ; middle tibial spur half as long as first tarsal joint; dark brown lines on dorsum of hind tibiæ forming no closed cells, but a continuous series of loops resembling three antique figures 5 superimposed. General colour dark metallic greenish-blue; antennæ light brown, scape entirely yellow; head and face yellow, except a large round spot of which the anterior ocellus is practically the centre and which reaches over the vertex and nearly to the eyes on either side; yellow scutellar spot large, together with the postscutellum nearly equalling the dark portion of the scutellum in length; tegulæ light brown; sides and venter of abdomen reddish yellow, except at base and tip; all legs, including front and middle coxæ, yellowish white with a translucent effect; lower half of hind coxæ concolorous with femora, upper half metallic; wing-veins dark brown. In other respects resembles $E$. levifrons.

Described from seven female specimens.

Elasmus helvus, sp. n.

ㅇ. Length $1 \cdot 6$ millim.; expanse $3 \cdot 4$ millim.; greatest width of fore wing 0.39 millim. Face and vertex punctured as in E. maculatus; first tarsal joint one fourth as long as tibia; dark brown lines on hind tibiæ as in $E$. rugosus; middle tibial spur about one third as long as first tarsal joint. General colour honey-yellow; all of head, pronotum, lateral angles of mesoscutum, scuto-scutellar furrow of mesonotum, upper half of hind coxæ, and last two joints of abdomen metallic blue-green; middle and hind femora edged above by a narrow black line; antennæ brownish above, yellow below. Wing-veins dark brown, disk of fore wings slightly infuscated; stigmal vein very plain, straight, and not knobbed, running obliquely into the disk for a distance equal to about one sixth the width of the wing at that point; a delicate circular fuscous patch just below stigma. In other respects resembles $E$. levifrons.

Described from one female specimen. 


\section{Elasmus flaves, sp. n.}

o. Length 1.5 millim.; expanse 2.7 millim.; greatest width of fore wing 0.34 millim. Resembles E. helvus, except in the following respects:-middle tibia one third longer than first tarsal joint, its spur one half as long as first tarsal joint; hind tibiæ one third longer than first tarsal joint, the dark lines on dorsal surface forming two very narrow apposite closed longitudinal cells, each extending the entire length of the tibia. Head yellow, mesoscutellum (except bright yellow apex) metallic; metanotum and irregular patches on sides of third and fourth abdominal joints also metallic; hind coxæ with a narrow rim only of the metallic colour. Wing-veins plain, stigmal normal.

Described from one male.

\section{Elasmus flaviventris, sp. n.}

․ Length 1.95 millim.; expanse 3.6 millim.; greatest width of fore wing 0.44 millim. Most resembles $E$. rugosus, from which it differs as follows:-Face and vertex punctured as in $E$. maculatus; scutellar spot very small; first tarsal joint of middle and hind legs shorter than tibia; middle tibial spur rather more than one third as long as corresponding first tarsal joint; hind coxæ whitish, except just at base ; tip of hind femora whitish; distal half of hind coxæ whitish; abdomen reddish yellow, except the two metallic apical joints and a small brown spot each side on the plane dorsum of segments 3 and 4 . Stigmal vein of fore wings plain, slightly longer than usual and slightly curved towards apex of wing.

ơ . Length 1.5 millim.; expanse 3.6 millim.; greatest width of fore wing 0.44 millim. Antenna proper exceptionally slender; scutellar spot absent, postscutellum alone showing a slight yellow spot; middle femora metallic only on upper and lower edge, disk yellowish.

Described from four females and one male.

\section{Elasmus Smithit, sp. n.}

․ Length 1.8 millim.; expanse 3.4 millim.; greatest width of fore wing 0.39 millim. Differs from $E$. levifrons as follows :Face and vertex punctured as in E. maculatus; abdomen shorter than head and thorax together; first tarsal joint of middle and hind legs slightly shorter than its tibia; middle tibial spur about one third as long as first tarsal joint; dark lines of hind tibia forming four closed cells, one long and one short covering the 
length of the sclerite, and two short ones to the outside; postscutellum only yellow; tegulæ metallic at base; all legs yellowish, except metallic base of hind coxæ; first and last two joints of abdomen metallic, the others reddish yellow; wing-veins dark, stigmal very distinct.

$0^{*}$. Length 1.5 millim.; expanse 3.1 millim.; greatest width of fore wing 0.37 millim. Differs from female, beyond the ordinary sexual characters, only in having second joint of abdomen reddish yellow, and all coxæ and femora metallic, except at tips.

Described from two females and three males. The males may not belong to this species, and indeed in some respects resemble more the following species- $E$. punctatus - than the females with which I have associated them. The balance of characters, however, places them here rather than with any of the other species in the St. Vincent collection.

Elasmus punctatus, sp. n.

ㅇ. Length 2.2 millim.; expanse $3 \cdot 4$ millim.; greatest width of fore wing 4.9 millim. Differs from $E$. levifrons as follows :Head and face punctured as in $E$. maculatus; middle tibial spur more than one third as long as first tarsal joint; dark lines on hind tibia forming two narrow, wavy, longitudinal cells, side by side, and each extending the whole length of the sclerite, just as in $E$. flavus. Head, entire trunk, and all coxæ and femora uniform dark metallic greenish-blue. Wing-veins dark, disk very slightly infuscated. In two of the five specimens the front femora are reddish at apical third, and the abdomen is reddish brown ventrally at base.

Described from five females.

\section{Subfamily ElaChistina.}

\section{EUplectrus, Westwood.}

\section{Euplectrus furnids.}

Euplectrus furnius, Walker, Ann. Mag. Nat. Hist. xii. p. 48 (=bicolor, Swed.). St. Vincent.

Represented by three males and one female.

Walker suspected the identity of this species with $E$. bicolor (Swederus) =Elachistus albiventris, Spinola, = Euplectrus maculiventris, Westwood; but a careful comparison of Thomson's description of $E$. bicolor with Walker's of $E$. furnius indicates. that they differ in mesonotal characters. 


\section{Miotropis, Thomson.}

Miotropis NIGRICANS, sp. n.

‥ Length 1.5 millim.; expanse 2.4 millim. . Head closely shagreened; eyes hairy; pronotum and mesonotum closely and finely punctate; the mesopostscutellum very finely rugose; metanotum smooth, its central longitudinal carina dividing anteriorly as well as posteriorly, the triangle formed by the anterior division wider than the nucha enclosed by posterior division, and with a slight spine-like elevation of the carina at point of division; hind coxæ faintly striate; petiole rugose; first abdominal tergite smooth, glistening; other tergites very faintly reticulate. Colour black; faint bluish reflections on head, pro- and mesonotum; antennæ and legs fuscous, tibiæ becoming ferruginous; all coxæ black; wings hyaline, veins brown.

ot. A single male, possibly of this species, but which is in such condition as to preclude careful study, seems to differ only in having the base of the abdomen yellowish above and below, fore and hind femora black except at distal end, and all tibiæ and middle femora very light yellowish white.

Described from two females and one male (?). St. Vincent.

Miotropis versicolor, sp. n.

ot. Length 1.4 millim.; expanse 2.4 millim. Smooth, shining; mesoscutum very faintly aciculate; eyes faintly hairy; median longitudinal carina faint, not dividing or projecting anteriorly, nucha broader than in $M$. nigricans. General colour bright honey-yellow, head lighter than thorax, approaching lemon-yellow; antennæ fuscous, with rather long lighter-coloured hairs ; mandibles brown; occiput black; pronotum, except posterior lateral angles, black; mesoscutum, except parapsides, black; metascutellum with a broad, somewhat crescent-shaped black band, following its anterior margin; abdomen black, except at base and tip, the black portion above including a large oval yellowish spot; all tarsi fuscous; wings hyaline, veins fuscous.

Described from one male. St. Vincent.

\section{Stenomesius, Westwood.}

Stenomesius PLATYNOTA.

Miotropis platynotæ, Howard, Report on Insects affecting the Orange, by H. G. Hubbard, Washington, Dept. Agriculture, 1885, p.217. Florida. One male and one female in the St. Vincent collection are 
referable to this species with some slight doubt, since faulty mounting obscures some of the characters. The types were reared in Florida from the larvæ of Platynota rostrana, Walker.

\section{Elachistus, Spinola.}

Elachistus caddatus, sp. n.

o. Length 1 millim.; expanse 2 millim. Front very deeply impressed; eyes naked; mesoscutum very deeply and coarsely pitted; mesoscutellum smooth; metanotum with undivided median longitudinal carina, which is not specially elevated in front; lower border of front and hind femora with a fringe of rather long delicate hairs; ovipositor extruded to a distance which is nearly as long as entire abdomen; abdomen flattened, oval, rather strongly incised behind, flattened above. Colour black, shining; face honey-yellow, occiput with black centre and yellowish border to eyes; all coxæ honey-yellow; other joints of legs light yellow-brown. Abdomen piceous; wings hyaline, veins translucent, colourless.

Described from one female specimen. St. Vincent.

This will evidently form a new genus. I know of no other species in the subfamily Elachistinæ which has a similar ovipositor, and there are probably other distinguishing characters. The single specimen at hand, however, lacks antennæ, and is otherwise in poor condition for generic description.

Elachistus scutellatus, sp. n.

ㅇ. Length 1.5 millim.; expanse 3 millim. Facial depression broad, reaching nearly to margin of eyes, sharply defined just below insertion of antennæ by an acute transverse ridge; eyes hairy; ocelli forming slightly curved line; head and face slightly rugose; head with sparse long hairs; pronotum and mesoscutum slightly shagreened, with sparse large punctures; mesoscutellum with no indication of a median furrow, faintly longitudinally and quite regularly striate; median longitudinal carina of the metanotum broad, not high, not acute, divided into the two elements of the anterior transverse ridge; nucha narrow; surrounded by an elevated margin continuous with the median longitudinal carina; metanotal alæ separated by slight but distinct oblique furrows converging posteriorly; abdomen flattened, oval, not incised; mesonotal bristles long. Colour black, subopaque; abdomen with a basal honey-yellow spot above and below ; antennal scape and pedicel and all legs, except hind coxæ 
honey-yellow ; wings hyaline; veins light brown, the stigmal club rather darker and bearing a pronounced uncus.

Described from two female specimens. St. Vincent.

Elachistud aureus, sp. $\mathrm{n}$.

ㅇ. Length $1 \cdot 8$ millim.; expanse $3 \cdot 4$ millim. Facial depression similar to that of $E$. scutellatus, except that the transverse ridge below antennal insertion is lacking; sides of the depression smooth and shining; front and vertex faintly shagreened and with sparse round punctures; eyes sparsely hairy; mesoscutum rather coarsely granulate; mesoscutellum nearly smooth, very faintly reticulate; a shallow median longitudinal suture arises from the anterior border of this sclerite and ends beyond its middle; metanotum irregularly, coarsely, and deeply reticulate in centre; longitudinal carina faint; alæ smooth; nucha broader than in E. scutellatus; abdomen long, ovate, flat. Colour bright metallic green, with golden reflections; antennal scape and all legs yellowish white, somewhat translucent; hind coxæ darker near base; flagellum of antennæ brownish; base of abdomen metallic, segments 3 to 5 brownish; wings hyaline, veins nearly white; stigmal club not darker.

$\sigma$. The central brown patch of abdomen is narrower, and the middle and hind coxæ are metallic. The antennæ become darker toward tip, club being nearly black. Otherwise agrees with female.

Described from one male and two females. St. Vincent.

Report on the Parasitic Cynipidæ, part of the Braconidæ, the Ichneumonidæ, the Proctotrypidæ, and part of the Chalcididæ.-Part II. By William H. Ashmead.

\section{Family BRACONID丑. \\ Subfamily BraconIn \\ Bracon, Fabr. \\ Table of Species.}

Wholly rufous or honey-yellow, except sometimes

the head .........................

Not entirely black $\ldots \ldots \ldots \ldots \ldots \ldots \ldots \ldots \ldots$

3.

Entirely black.

Plate of second abdominal segment not entirely separated from the surrounding surface. (Length $2 \frac{1}{2}$ millin.). $\sigma^{\top} \ldots \ldots \ldots \ldots \ldots, B$. niger. 
2. Head, thorax, and legs black.

Abdomen rufous, the sutures deeply incised; wings black, the stigma yellow. of $f$...

Abdomen piceous, the sutures not deeply incised; wings dusky, the stigma brown. $9 . . . .$.

Abdomen yellow, the sutures not deeply incised; wings fuliginous, the stigma brown-black; tarsi piceous. 0 . $\ldots \ldots \ldots \ldots \ldots \ldots \ldots$. Head, pronotum, pectus, and legs black.

B. xanthospilus.

B. niger.

B. seminiger.

Abdomen rufous; the sutures deeply incised; wings smoky, the stigma yellow. 0 o $\ldots . .$.

3. Head above black or piceous.

Thorax, anterior and middle coxæ and trochanters, the second joint of the posterior trochanters, posterior knees, and abdomen rufous. ㅇ.. Head not black.

Rufous; wings black, with a streak in the first submarginal cell and a spot behind the recurrent nervure white. Legs black, all coxæ, middle femora beneath and the posterior femora rufous. $o f \quad \ldots \ldots \ldots \ldots \ldots \ldots$ Honey-yellow or pale ferruginous.

Wings subhyaline, iridescent; legs entirely pale; no plate or foveolæ on the second abdominal segment. 0 of $\ldots . . . . .$. Wings smoky or blackish; tips of posterior tibiæ and tarsi black or fuscous; a plate and foveolæ on second abdominal segment. 0 우

B. flavomaculatus.

B. maculiceps.

B. femoratus.

B. Sancti-Vincenti.

B. vulgaris.

BraCoN NIGER, sp. n.

of 9 . Length $2 \frac{1}{2}$ millim. to 3 millim; ovipositor longer than the abdomen. Black, shining, impunctured; the female abdomen piceous. Palpi yellow. Antennæ in female 33-jointed, in male 29-jointed. Thorax with a middle lobe prominently convex anteriorly, but without distinct furrows. Pleura and metathorax smooth, polished, the metapleura with a spiracular furrow. Wings dusky hyaline or blackish, the venation brown; the second abscissa of the radius is about two and a half times as long as the first; the second submarginal cell therefore very long, or as long as the third along its upper margin and a little longer along its lower margin; the recurrent nervure not interstitial, rejected, joining an angle in the first submarginal cell. Abdomen smooth, shining; the first segment is a little longer than the second, with side furrows that converge at base and 
form a wedge-shaped shield; the second segment has two irregular grooved lines on each side of the middle that extend posteriorly about two-thirds the length of the segment; the suture between the second and third segments crenate; fourth segment with a transverse grooved line near the base.

Hab. St. Vincent.

Described from one male and one female specimen.

\section{Bracon Xanthospilus, sp. $n$.}

o 9 . Length 7 to 8 millim.; ovipositor not quite half the length of the abdomen. Black, polished, covered with a sparse white pubescence; abdomen dark rufous, the two terminal segments black. Head subquadrate, narrowed behind the eyes. Palpi piceous. Antennæ longer than the body, black, multiarticulate, the joints after the third, to near the tips, not longer than wide. Thorax wholly smooth, shining, the metapleura separated from the dorsum of metathorax by a broad, smooth furrow, the spiracles round, situated just above the furrow at about its middle. Wings black, the stigma yellow; in the male the two basal cells are nearly hyaline, and nearly the whole of the first submarginal cell and a spot behind the recurrent nervure are white; the female also has a streak across the first submarginal cell and behind the recurrent nervure white, but not so large or distinct as in the male, while the basal cells are not hyaline. Abdomen ovate, the sutures deeply incised; the first segment has broad, crenate, lateral furrows with a subcordate shield; the second segment has a triangular shield at its basal middle, with broad oblique foveæ toward the sides; all the segments are smooth, shining, and impunctured.

Hab. St. Vincent.

Described from two male and two female specimens.

\section{Bracon SEMiniger, sp. n.}

o. Length 3 millim. Smooth, shining; head, thorax, and legs black; abdomen yellow. Head quadrate, not narrowed behind the eyes. Antennæ black, not quite as long as the body, all the joints being longer than wide. Wings fuliginous; the second abscissa of the radius is a little more than thrice as long as the first, the second submarginal cell therefore very long; the recurrent nervure is interstitial with the first transverse cubital nervure. Abdomen smooth, impunctured, linear, much 
longer than the head and thorax together, the first segment the longest, with a triangular raised shield posteriorly, the second and following smooth, without shield ; the sutures are not deeply incised.

Hab. St. Vincent.

Described from a single specimen, in poor condition.

\section{Bracon flatomaculatus, sp. $n$.}

o ㅇ. Length variable, from $3 \frac{1}{2}$ millim. to 6 millim.; ovipositor about one third the length of abdomen. Rufous; head, antennæ, pronotum, pectus, and legs black; in the male the mesopleura are also black. The face, cheeks, pectus, and coxæ are covered with a whitish pubescence. Head subquadrate, narrowed behind the eyes. Metapleura separated from the dorsum of the metathorax by a furrow; the spiracles very minute, round, situated at about the middle of the suture. Abdomen ovate, the sutures deeply incised, the first segment longer than the second, with crenate furrows laterally forming a wedge-shaped shield; the second segment with a triangularshaped shield at its basal middle, not entirely separated at its apex from the surrounding surface; on each side of this shield are deep oblique foveæ; the third segment has oblique grooved lines at its basal angles; the fourth segment with a transverse crenate furrow across the basal one-third. Wings black, the stigma yellow; the recurrent nervure is interstitial with the first transverse cubital nervure; the second abscissa of the radius is about four times the length of the first, the second submarginal cell therefore very long; the third submarginal cell is only a little longer than the second.

$H a b$. St. Vincent.

Described from one female and 17 male specimens.

\section{Bracon maculiceps, sp. n.}

․ Length 3 millim.; ovipositor half the length of the abdomen. Rufous; head above, antennæ, wings, ovipositor, and legs (except anterior pair, middle coxæ, trochanters, tarsi, and second joint of posterior trochanters and posterior knees) black. Abdomen ovate, the sutures not deeply incised; the first segment with a wedge-shaped shield, the second with a triangular raised piece at the basal middle with a depression on each side of the piece. Wings dusky or black; the second abscissa of radius is 
about two and a half times as long as the first, the recurrent nervure rejected.

Hab. St. Vincent.

Described from a single specimen.

Bracon femoratus, sp. $\mathrm{n}$.

o ․ Length $2 \frac{1}{2}$ to 8 millim.; ovipositor about half the length of abdomen. Rufous; antennæ, wings, and legs, with the exceptions herein afterwards mentioned, black; all coxæ, middle femora beneath, and the posterior femora rufous; in the male the anterior tarsi are pale. The whole surface, except the face, which is shagreened, is smooth and shining. Head transverse. Palpi in the female black, in the male white. Antennæ shorter than the body, the joints after the third transverse. Metapleura separated from the dorsum of metathorax by a furrow; the spiracles small, rounded. Abdomen ovate, the sutures not deeply incised; the shield of the first segment wedge-shaped, the second segment smooth, without a shield, and with but faint traces of the oblique furrows at the sides. The second abscissa of the radius is about four times as long as the first, the recurrent nervure rejected, while there is a white streak across the first submarginal cell and a white spot behind the recurrent nervure.

Hab. St. Vincent.

Described from 4 female and 12 male specimens.

Bracon Sancti-Vincenti, sp. n.

ơ ㅇ․ Length $1 \frac{1}{4}$ to 2 millim.; ovipositor short. Entirely honey-yellow or pale ferruginous; antennæ and eyes black or brown-black; wings greyish hyaline, iridescent, the nervures brown; the second abscissa of the radius is about two and a half times as long as the first, the recurrent nervure rejected. The whole surface is smooth, shining, impunctured. Abdomen orate, the sutures not deeply incised; the first segment with a wedgeshaped shield, the following smooth.

Hab. St. Vincent.

Described from 24 individuals.

BracoN vULGaris, sp. $n$.

o 9 . Length $2 \frac{1}{2}$ to 4 millim.; ovipositor not quite as long as the abdomen. Honey-yellow or pale ferruginous ; the antennæ black; wings fuliginous; tips of the posterior tibiæ and their tarsi fuscous or black. As in B. Sancti-Vincenti, its whole surface 
is smooth, shining, impunctured, and the venation of the wings is identical. The second abdominal segment, however, has a subtriangular shield at its basal middle, which is not entirely separated at apex from the surrounding surface; there are also two shallow oblique lines on each side of the shield.

Hab. St. Vincent.

Described from many individuals of both sexes.

This species varies greatly in size, in the colour of the body, from a honey-yellow to pale rufous, and in the density of the colour of the wings.

\section{Mrosoma, Brullé.}

Mrosoma pilosipes, sp. n.

o. Length 3 millim. Head above, antennæ, streak on pronotum, wings, tip of abdomen, and legs black; face, thorax, coxæ, and trochanters and abdomen rufous; the base of anterior tibiæ and tarsi and the base of middle tibiæ pale. The whole surface is smooth, shining, impunctured, sparsely hairy ; the legs rather densely pilose. Antennæ about 36-jointed. Wings black; the second abscissa of the radius is about two and a half times as long as the first, or a little longer than the third; the second submarginal cell therefore long, as wide at apex as at base; the first transverse cubital nervure oblique, not interstitial with the recurrent nervure; the second transverse cubital nervure straight; the median and submedian cells are of an equal length; there is a hyaline or whitish streak across the base of the first submarginal cell that is extended into the third discoidal cell behind the recurrent nervure, while there is also a whitish streak in the second discoidal cell near the discoidal nervure. Abdomen ovate, the first segment the longest, with lateral furrows; the shield wedge-shaped, convex, smooth; second segment transverse, slightly longer than the third, with a fovea on each side of the basal middle, forming a small triangular shield that is not entirely separated behind, and on each side of these foveæ is another oblong foveola; the third segment has a curved impressed line at its basal middle that forms a small lunate or semicircular shield, and laterally with oblique grooved lines that extend into lateral foveolæ; while the fourth segment has two transverse impressed lines.

Hab. St. Vincent.

Described from two specimens. No species in this genus has yet been described from the North-American fauna, and the 
present species is quite different from the three or four species known from South America.

\section{Microbracon, Ashmead.}

(Bull. no. 1, Col. Biol. Assoc. 1890, p. 15.)

\section{Microbracon pilosithorax, sp. n.}

o. Length 2 millim. Black, finely punctulate, but shining, and covered with sparse, glistening, white hairs; orbits, face, mandibles, palpi, legs, and most of the abdomen yellow; the shield of first and the dorsum of third and fourth abdominal segments brown. Antennæ 30-jointed, black. Mesopleuræ with a small fovea at the middle of its posterior margin. Metathorax finely shagreened, the metapleura bounded above by a delicate carina; the spiracles small, inconspicuous. Wings subhyaline, the first abscissa of the radius only a little shorter than the second, the third abscissa about twice the length of the second; the second transverse cubital nervure is short, the second submarginal cell, therefore, narrower at apex than at base, while the recurrent nervure is not longer than the second branch of the cubitus : in the hind wings the radial and cubital nervures are abbreviated and do not extend to the apical margin. Abdomen oval, shagreened, the second segment as long as the first, without shield, furrow, or foveola, the following segments subequal.

Hab. St. Vincent.

Described from a single specimen.

\section{Subfamily Spathita 2.}

\section{Stenophasmus, Smith.}

\section{Stenophasmus terminalis, $\mathrm{sp} . \mathrm{n}$.}

o 9 . Length 3 to 6 millim.; ovipositor longer than the body. Ferruginous, the abdominal segments usually more or less banded with dusky, especially toward apex, rarely entirely fuscous; sometimes the thorax more or less fuscous; the posterior legs usually with brownish or fuscous markings.' Wings subfuscous, the venation brown. Head quadrate, smooth, except some transverse aciculations on the vertex. Ocelli contiguous, in a triangle. Antennæ longer than the body; in the female the four or five apical joints white; in male dusky or fuscous, the tips never white. Thorax trilobed, more or less transversely rugose; scutellum smooth on the disk; mesopleura with some longitudinal striæ superiorly; sternum sometimes black or fuscous, smooth; 
metathorax rather long, with delicate lateral keels, and more or less lineately rugose. Abdomen longer than the head and thorax together; the petiole very long, as long as the posterior femora and trochanters together; the petiole, second segment, basal half of third, and the fourth segment opaquely shagreened; rest of the abdomen smooth, shining.

Hab. St. Vincent.

Described from 23 specimens. The species is exceedingly variable in size and somewhat in colour, but is readily distinguished from the other described species by the white tips of the female antennæ.

Subfamily Hecabolina.

\section{Heterospilus, Haliday.}

Table of Species.

Females.

Second abdominal segment with one or more transverse impressed lines or sutures............. Second abdominal segment without a transverse impressed line or suture.

Dark ferruginous ; antennæ fuscous, the two basal joints and the sutures of all the joints, and the legs white or pale luteous, the legs with some brown markings; first and second abdominal segments and the basal half of the third striated.

Black, opaque, minutely rugose; antennæ pale brown, yellowish basally; legs black; knees, tips of tibiæ, and tarsi honey-yellow; first abdominal segment and the basal half of the second opaquely sculptured $\ldots \ldots \ldots \ldots$.

2. Second abdominal segment with one transverse

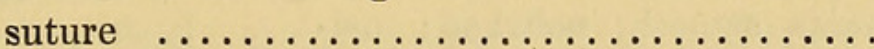

Second abdominal segment with three transverse sutures longer than the first.

Thorax and abdomen black or fuscous; head, collar, legs, band at base of second abdominal segment, and the apex of abdomen luteous or white; first abdominal segment and the second to the third transverse suture, and the basal portion of the third, striated or aciculated; the apex of the second segment and the rest of the abdomen smooth, polished $\ldots \ldots \ldots \ldots \ldots \ldots$.

2.

H. ferruginus.

H. carbonarius.

3.

H. fasciatus. 
Second abdominal segment with two transverse sutures.

Pale ferruginous with fuscous markings; legs pale luteous.

First transverse suture of the second segment at the middle, the second at the apical onethird of the upper half; first segment and basal half of the second, and the bottom of the second suture striated or aciculated; the rest of the abdomen, except some faint aciculations at the bottom of a transverse suture on the third segment, smooth, polished; ovipositor as long as the abdomen $\ldots \ldots \ldots \ldots \ldots \ldots \ldots \ldots . \ldots . \ldots . \ldots$

First transverse suture of the second segment

H. pallidipes. curving inwardly at sides; the second suture straight, close to the apex of the segment; the third, fourth, and fifth segments with dark transverse bands ; ovipositor much longer than the abdomen; first segment and the second, except the apex, striated $\ldots \ldots \ldots \ldots \ldots \ldots \ldots \ldots \ldots \ldots$

3. Second abdominal segment shorter than the first, or equal. .......................

Second abdominal segment longer than the first.

Suture of second segment at about one-half the length of the segment, not arcuated.

Black, the head reddish, legs and two basal joints of antennæ white; third abdominal segment with a broad transverse suture before the middle, the basal portion very faintly and the broad suture distinctly aciculated, the apical portion and the following segments smooth, polished; ovipositor half the length of the abdomen....

4. Suture of the second segment at about one-third

H. nigrescens.

\section{H. longicaudus.}

4.

the length of the segment, arcuated, in middle nearly obsolete.

Pale ferruginous, head, legs, and apex of abdomen luteous or white; first abdominal segment and the basal two-thirds of the second striated, the third showing some faint aciculations at base; the following segments rarely slightly punctate basally, usually smooth...............

H. quastor, Hal. 
Variable, from ferruginous to luteous.

Mesopleura, sutures of thorax and metathorax above, and basal four abdominal segments dark fuscous or black ; suture of second segment at about the middle, bending inwardly toward the sides; first segment and basal two-thirds of the second striated; the following two or three segments finely punctate at base, rest of the abdomen smooth . .

Mesopleura, humeri, and base of metathorax more or less fuscous, rest of the insect, except legs, pale ferruginous; suture of second segment near the middle, subobsolete ; first segment, basal two-thirds of second, and at the bottom of a depression near the base of third, striated or aciculated, rest of the abdomen smooth $\ldots \ldots \ldots \ldots$.

H. variegatus.

H. humeralis.

\section{Heterospilus ferruginus, sp. n.}

․ Length $4 \frac{1}{2}$ millim.; ovipositor 3 millim. Reddish brown, the thorax beneath and at sides blackish; antennæ brown, the incisions of joints whitish; legs whitish, all femora with a subapical reddish annulus, base and tips of tibiæ with reddish markings. Head quadrate, rugose, the vertex transversely aciculated. Antennæ 24-jointed, a little shorter than the body, the two basal joints white. Thorax rugose, the middle lobe of mesonotum prominent, reaching only to half the length of the mesonotum; disk of mesopleura smooth, polished; metathorax rugose, not areolated, and with only an abbreviated central keel at base. Wings fusco-hyaline, mottled toward tips with whitish spots or streaks. Abdomen much longer than the head and thorax together, the two basal segments and the basal half of the third opaque, finely striated; rest of the abdomen smooth, polished.

Hab. St. Vincent.

Described from a single specimen, taken in a forest at Morne à Garon, at an altitude of 1500 feet, under the bark of a stump, October 31.

Heterospilus carbonarius, sp. n.

ㅇ. Length 2 millim.; ovipositor half the length of body. Black, opaque, finely, closely, confluently punctate, covered with a sparse white pubescence. Legs black or brown-black; the tibiæ at base, tips, and the tarsi honey-yellow. Head quadrate; 
eyes large, subrotund, black. Antennæ 22-jointed, fuscous, the flagellum a little yellowish toward base. Thorax with the middle lobe prominent, rounded before, reaching only to half the length of the mesonotum; pleura closely punctate; metathorax not areolated, closely punctate, rugose toward tip. Wings hyaline, with a slight dusky streak in the region of the basal vein and below the stigma. Abdomen sessile, longer than the head and thorax together; the first and second segments about equal, quadrate, the first wholly and the basal half of the second lineately rugose ; rest of the abdomen smooth, polished.

Hab. St. Vincent.

Described from a single specimen.

\section{Heterospilus fasciatus, sp. n.}

$\sigma^{*}$. . Length 2 to 5 millim.; ovipositor 4 millim. Head, collar, legs, broad band on second abdominal segment, and the apex of abdomen honey-yellow or luteous; rest of the insect, except the antennæ which are fuscous, black. Sometimes the anterior portion of the mesonotum and the pleura are pale, rarely with most of the thorax pale. Head quadrate, smooth; eyes large, rounded, very slightly sinuated within opposite the antennæ. Antennæ long, setaceous, from 30- to 34-jointed, the four or five basal joints pale. Thorax polished, with a few sparse hairs, the furrows large, distinct, converging and meeting at base of scutellum, the sides of the grooves margined within; collar distinct, narrowed before, rugose above; scutellum with two large foveæ at base, separated by a slight carina; mesopleura smooth, with an oblique fovea at the middle; metathorax rugose, areolated, the two long areas at base nearly smooth, a diamondshaped area at the middle extending to the apex and connected with the base by a central carina, the surface of the area being rugose; metapleura rugose. Wings subhyaline, the stigma large, black or brown; the venation brown, the transverse vein between the first and second submarginal cells subobsolete or entirely wanting. Abdomen sessile, longer than the head and thorax together; the first segment longer than the second, narrowed toward base; the second segment quadrate, with three crosslines or sutures, the first a little before the middle, the second at about one-third the length of the remaining portion, the third visible only at the sides and curving to the posterior angles of the segment; the third segment also has a cross-line or suture; 
the first segment, basal two-thirds or more of the second, basal half of the third, and the fourth slightly at base longitudinally striated or aciculated; rest of the abdomen smooth, polished.

The male, which is very variable in size and colour, is usually pale or ferruginous, although sometimes presenting an exact colour-pattern of the female. Sometimes it is wholly pale, with only the metathorax, first abdominal segment, and two or three of the following segments dusky ; the basal portion of the second segment, however, is always more or less distinctly yellow, and the sculpture is identical, or nearly so, in both sexes. The antennæ vary from 22- to 29-jointed.

Hab. St. Vincent.

Described from many specimens of both sexes.

Heterospilus pallidipes, sp. $n$.

o 9 . Length $1 \frac{1}{2}$ to 3 millim.; ovipositor a little longer than the abdomen. Pale ferruginous; orbits, lower part of head, streak on collar, and legs white or luteous. Collar, humeri, mesopleura, and metathorax more or less fuscous. Head quadrate, smooth, except the vertex, which is transversely aciculated. Eyes very large, rounded, slightly sinuated within. Thorax finely shagreened, the furrows distinct, the middle lobe posteriorly in front of the scutellum with three or four raised lines; scutellum smooth, polished; metathorax areolated, rugose, the surface of the two large basal areas finely, closely punctate, the diamond-shaped area nearly obliterated by the rugosity of its surface. Wings subhyaline, the venation brown, the first and second transverse nervures subobsolete. Abdomen not longer than the head and thorax together; the second segment longer than the first, with two transverse impressed lines, the first at about half its length, the second at about one-third the length of the remaining half; the third segment also with a transverse, impressed line; the first segment and the basal half of the second longitudinally striated, the transverse impressed line on third aciculated at bottom; rest of the abdomen smooth, polished.

The male is uniformly pale ferruginous, and in sculpture agrees with the female.

Hab. St. Vincent.

Described from one male and two female specimens.

Heterospilus longicadpus, sp. $\mathrm{n}$.

․ Length 4 millim.; ovipositor 3 millim. Pale ferruginous, 
with fuscous tingeings in the sutures; antennæ dusky toward tips; legs honey-yellow. Head quadrate, smooth, the vertex transversely aciculated. Thorax shagreened, narrowed in front; the collar produced, striated at sides; parapsidal furrows distinct, the middle lobe rugose posteriorly; scutellum smooth, with a crenulated furrow across the base ; pieura and metathorax rugose, the latter not areolated. Wings greyish-hyaline, strongly iridescent, the venation brown, the costa basally yellow, the transverse nervures of the second and third submarginal cells subobsolete. Abdomen longer than the head and thorax together, the base of third and fourth segments and the apex of the fifth and sixth embrowned; the second segment is longer than the first, with a transverse impressed line at about its middle that curves basally at the sides, and another straight subapical transverse line ; first segment and the second, except near the apex, striated, the following segments, except the last two, microscopically punctate.

Hab. St. Vincent, leeward side.

Described from a single specimen.

Heterospilus nigrescens, sp. $n$.

ㅇ. Length $2 \frac{1}{2}$ millim.; ovipositor shorter than the abdomen. Black; the head reddish brown, with transverse aciculations on the vertex; antennæ 24-jointed, brown, the two basal joints white. Thorax shagreened, opaque; scutellum smooth, shining, with a transverse crenulated furrow at base ; pleura shagreened; metathorax rugose, areolated. Wings subfuscous. Abdomen as long as the head and thorax together, the second segment shorter than the first, with a depression at the middle; first segment and the second, except the apical one-third, striated, the following segments smooth, polished, the third with a transverse suture, the bottom of which is faintly aciculated.

Hab. St. Vincent.

Described from a single specinien, taken at 1500 feet altitude.

\section{Heterospilus variegatus, sp. $n$.}

o $q$. Length 2 to $3 \frac{1}{2}$ millim.; ovipositor about as long as the abdomen. Pale ferruginous to luteous, sutures of thorax, metathorax, and upper portion of four or five basal abdominal segments black; antennæ pale brown; legs white. Head with faint transverse aciculations on the vertex. Thorax very faintly shagreened, the parapsidal furrows distinct, the middle lobe 
rugose posteriorly; metapleura with a crenulate furrow across the disk; metapleura areolated, the central diamond-shaped area rugose, the two large basal areas shagreened. Wings subhyaline, the transverse nervures between the second and third submarginal cells subobsolete. Abdomen as long as the head and thorax together, the first segment and the basal two-thirds of the second striated, the three following segments finely punctate along the base; the second segment is longer than the first in the male, shorter in the female.

Hab. St. Vincent.

Described from one male and two female specimens.

\section{Heterospilus humeralis, sp. $\mathrm{n}$.}

o $q$. Length 2 to $2 \frac{1}{2}$ millim.; ovipositor shorter than the abdomen. Pale ferruginous, the mesopleura, humeri, and base of metathorax more or less fuscous or dusky; legs white or luteous. Head smooth, transversely aciculated on vertex. Thorax faintly shagreened, the parapsides distinct, the middle lobe roughened posteriorly; metathorax rugose, areolated. Wings. subfuscous; the stigma large, brown; the venation pale. Abdomen not longer than the head and thorax together, the first and second segments about equal, longitudinally striated, except the apex of the second, which is smooth and polished, the third segment aciculated at base, rest of the abdomen smooth, shining.

The male in structure and colour closely resembles the female, except the apex of the abdomen is slightly embrowned and the mesopleura are smoother and more shining.

Hab. St. Vincent.

Described from 1 male, 7 female specimens.

\section{Lysitermus, Förster.}

\section{Table of Species.}

Pale ferruginous; wings hyaline; the last antennal joint

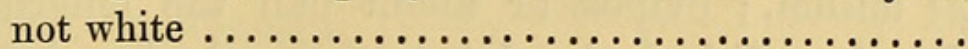

L. terminalis.

Dark brown ; wings with a transverse band ; the last antennal joint white..................... L. fascipennis.

LYSITERMUS TERMINALIS, sp. $\mathrm{n}$.

ㅇ. Length $1 \frac{1}{2}$ millim.; ovipositor half the length of the abdomen. Pale ferruginous, smooth, polished; mesopleura, apical half of abdomen, and ovipositor black; legs pale yellow.

LINN. JOURN.—ZOOLOGY, VOL. XXV. 
Head subglobose, the eyes brown. Antennæ 17-jointed, longer than the body. Mesonotum with two punctate furrows that converge and meet before the scutellum, the middle lobe finely, sparsely punctate, truncate anteriorly with acute angles. Mesopleura with a crenulate fovea near the middle. Metathorax finely rugose, with a delicate central longitudinal keel and lateral keels. Wings hyaline, the margins with short cilia, the venation brown, and with only two submarginal cells; stigma distinct, the first branch of radius long, the second branch extending to the apical margin, the marginal cell therefore large. Abdomen oblong-oval, depressed, polished, blackish towards apex, and composed of only three visible segments.

Hab. St. Vincent.

Described from a single specimen.

\section{LYSITERMUS FASCIPENNIS, sp. n.}

․ Length $1 \frac{1}{4}$ millim.; ovipositor two thirds the length of the abdomen. Dark reddish brown, polished, impunctate; mesoand metapleura and apical half of the abdomen black; legs honey-yeilow, the apical half of the posterior femora embrowned. Head subglobose, the eyes oval, brown. Antennæ 14-jointed, fuscous, the four basal joints yellowish, the apical joint white. Mesonotum without furrows, smooth, polished, the anterior angles acute. Metathorax finely rugose, with a central longitudinal keel and lateral keels. Wings hyaline, with a transverse brown band below the stigma, and of the same width. Abdomen oblong-oval, polished, of three segments, the first finely aciculated or striated.

Hab. St. Vincent.

Described from a single specimen.

\section{Subfamily Pambolina.}

\section{Pambolus, Haliday.}

\section{Pamboldos anndlicornis, sp. $n$.}

ㅇ. Length $2 \frac{1}{2}$ millim.; ovipositor about half the length of the abdomen. Black, polished; head transverse, the face below the antennæ finely punctate. Antennæ dark brown, the two basal joints and a broad band beyond the middle honey-yellow. Thorax smooth, impunctate, the parapsidal furrows distinct, converging posteriorly, the middle lobe with two short carinæ posteriorly; scutellum polished, with five foveæ at base; mesopleura finely punctulate, with an oblique, crenulate furrow 
anteriorly; metathorax rugose, with two areas at base. Wings hyaline, the second and third submarginal cells confluent. Legs, including coxæ, honey-yellor. Abdomen sessile, oblong-oval, the second segment longer than the first, with a cross-furrow at aboutits middle; the first segment, basal two-thirds of the second, and the third at base longitudinally striated.

Hab. St. Vincent.

Described from a single specimen.

\section{Dimeris, Ruthe.}

Dimeris maculipennis, $\mathrm{sp} . \mathrm{n}$.

ot. Length 1 millim. Brown, the head blackish on the vertex. Antennæ 16-jointed, pale. Thorax smooth, narrowed in front, with two delicate furrows that converge and meet before attaining the base of the scutellum. Scutellum with a large fovea across the base. Metathorax finely rugose, areolated. Wings subfuscous, with spots at base, across the middle, and in the radial cell white. Abdomen finely punctate, composed of three segments, the first the longest, the third the shortest. Legs honey-yellow, tips of posterior femora and tibiæ brown.

Hab. St. Vincent.

Described from a single specimen.

\section{Subfamily RHOGADIN}

RHOGas, Nees.

RHOGas peCtoralis, sp. n.

0 ㅇ․ Length 4 to 5 millim. Black, opaque, closely, finely punctulate; the mouth-parts, legs, and thorax beneath honeyyellow. Wings fuliginous, the first branch of radius as long as the second. Metathorax, the first, second, and basal half of the third abdominal segment with a delicate central keel; the fourth and following segments slightly shining. Ovipositor in female very slightly exserted.

Hab. St. Vincent.

Described from one female and four males, taken at an altitude of 1500 feet.

\section{Cuinocentrus, Haliday.}

Chinocentrus flaviventris, $\mathrm{sp} . \mathrm{n}$.

o. Length $3 \frac{1}{2}$ to $4 \frac{1}{2}$ millim. Entirely black, shining, pubescent; the apex of abdomen, along the sides, and the venter alone, 
yellow. Head transverse, smooth above; orbits and face, below antennæ, punctate. Palpi fuscous. Antennæ 36-jointed, longer than the body. Thorax trilobed, the middle lobe posteriorly rugose, the mesopleura with a smooth space on the disk. Scutellum smooth, with two large, confluent foveæ at base. Metathorax coarsely rugose. Wings fuliginous. Abdomen compressed along the venter and slightly at tip, the first and second segments above black, striated, the following segments smooth, the third with a black spot at base and showing some faint transverse aciculations.

Hab. St. Vincent.

Described from five specimens, taken at an altitude of 500 feet.

\section{Subfamily CheLonina. \\ Рнжпотома, Wesmael. \\ Table of Species.}

Pale ferruginous or honey-yellow, varied more or less with fuscous.

Thorax trilobed..........................

Thorax not trilobed.

Occiput deeply emarginated; first branch of radius distinctly longer than the second $\ldots \ldots \ldots \ldots, P$. insularis.

Occiput not deeply emarginated; first branch of radius half the length of the second $\ldots \ldots \ldots \ldots$.

P. humeralis.

2. First branch of radius as long as or longer than the second. First transverse cubital nervure not interstitial with the recurrent nervure, but joined to the cubital nervure $\ldots \ldots \ldots \ldots \ldots \ldots \ldots \ldots, P$. meridionalis.

First transverse cubital nervure interstitial ....... P. fuscovaria.

\section{Phenotoma insularis, $\mathrm{sp}$. $\mathrm{n}$.}

o. Length 4 millim. Pale ferruginous, closely, finely punctulate; a spot back of eyes and ocelli, the humeri, a spot on middle of thorax, collar beneath, the bottom of the impression at sides, the sternum, spot beneath tegulæ, and metathorax and the abdomen above except an oblong discal spot, a spot on middle and posterior femora beneath near the apex, and the posterior tibiæ, except just at base, fuscous. Antennæ 23-jointed, tapering at tips. Head broader than the thorax, deeply excavated posteriorly. Thorax without furrows; scutellum triangular; metathorax short, finely rugose, with a slight keel on the superior edge of the posterior face connected with delicate lateral keels, the disk without keels. Wings subhyaline, mottled with whitish 
spots, the venation brown, the stigma with a large yellowish streak; the first branch of the radius longer than the second, the first transverse cubital nervure interstitial with the recurrent nervure.

Hab. St. Vincent.

Described from a single specimen, taken at an altitude of 2000 feet. The species approaches closest to P. tibialis, Hal., but is decidedly different in the venation.

\section{Рhenotoma humeralis, sp. n.}

o. Length 4 millim. Pale ferruginous, closely, finely punctulate; shoulders, the depressions at sides of scutellum, and apex of metathorax fuscous. Head transverse, the occiput scarcely emarginated. Antennæ 24-jointed, acuminated at tips, pale ferruginous, the four or five small apical joints black. Thorax without furrows, the disk flattened. Metathorax with a slight carina on the superior edge of the posterior face, the face itself rugose. Wings hyaline, the venation pale, the costal edge and stigma darker, the latter with a pale streak in the middle; first branch of radius only half the length of the second, the first transverse cubital nervure interstitial with the recurrent nervure and at the junction very pale. Legs pale. Abdomen of three segments, the last segment the longest.

Hab. St. Vincent.

Described from a single specimen. The pale colour, shape of the head, and the shortness of the first branch of the radius readily distinguish the species.

Phenotoma meridionalis, sp. n.

đ. Length 3 to 4 millim. Pale ferruginous or honey-yellow, finely, closely punctulate, with fuscous or black markings on thorax; the metathorax and upper surface of the abdomen black or fuscous; sometimes the latter has a rounded yellow discal spot, sometimes it is pale with an irregular, central stripe; the metathorax usually has two pale spots at base. Head large, transverse, excavated posteriorly, with the stemmaticum black. Antennæ pale, multiarticulate. Thorax with the parapsidal furrows obsolete posteriorly before reaching the base of the scutellum. Axillæ meeting as a slender line before the base of the scutellum. Metathorax rugose, with an irregular carina on the superior edge of the posterior face. Legs pale. Wings subbyaline, the venation pale brownish, some of the nervures 
more or less tinged with yellow; the first branch of the radius equal to the second, or very slightly longer; the first transverse cubital nervure is not interstitial with the recurrent nervure, but joins the cubital nervure. Abdomen of three segments, the first and last about equal, the second the shortest, all striate-rugose.

Hab. St. Vincent.

Described from five specimens, taken at an altitude of 500 feet. The species is near $P$. humeralis; but the distinct parapsidal furrows, the length of the first branch of the radius, and in that the first transverse cubital nervure joins the cubital nervure, separate it at once from the foregoing and the following species.

Рhжnotoma fuscotaria, sp. n.

$\delta$. . Length $2 \frac{1}{2}$ to 4 millim. Pale ferruginous or honeyyellow, finely rugose-punctate, with variable fuscous markings; sometimes it is wholly pale, with only the apex of the antennæ and the abdomen fuscous; sometimes there is a central fuscous stripe on the mesonotum, metathorax, and abdomen, the scutellum being wholly fuscous; sometimes the mesopleura, metathorax, tip of abdomen, apex of posterior tibiæ and their tarsi are dusky or fuscous, although usually the legs are of a uniform pale colour. Wings greyish-hyaline, the venation brown; the first and second branches of the radius about equal in length, while the first cubital nervure is always interstitial with the recurrent nervure. Abdomen of three segments, the first and third segwents about equal, the second a little shorter, all striaterugose, the first with two distinct keels above.

Hab. St. Vincent.

Described from 31 specimens.

\section{Chelonus, Jurine.}

Chelonus meridionalis, $\mathrm{sp} . \mathrm{n}$.

o 9 . Length $2 \frac{1}{2}$ to 3 millim. Black, rugose, covered with a sparse, sericeous pubescence. Antennæ 16-jointed, the two basal joints yellowish, or at least beneath. Thorax, in the middle posteriorly, coarsely rugose. Scutellum smooth, polished, with a row of coarse punctures across the base. Metathorax with two median keels connected with a keel on the superior edge of the posterior face, the angles slightly prominent. Legs honey-yellow, all coxæ, middle and posterior femora, the apical half of their tibix, and four apical joints of their tarsi black or fuscous. 
Wings hyaline, the apical half faintly dusky; the venation, except the costa and median veins which are yellow, brown; the first branch of the radius is shorter than the second, the first transverse cubital nervure a little longer than the recurrent nervure. Abdomen one solid carapace, rugose, with two short keels at base; ovipositor slightly exserted. In the male the antennæ are 20-jointed, all the femora black, while the abdomen has a slight transverse slit at apex.

Hab. St. Vincent.

Described from 10 specimens.

\section{Subfamily Rhyssaline.}

\section{Rhyssalus, Haliday.}

RHYSSALUS CANOPHANOIDES, sp. $n$.

o. Length $2 \frac{1}{2}$ millim. Pale ferruginous, smooth, shining; tip of abdomen piceous. Antennæ black, the two basal joints pale. Thorax trilobed, the middle lobe with a grooved line posteriorly. Scutellum with a crenate furrow across the base. Metathorax finely rugose, areolated. Legs honey-yellow. Wings greyish-hyaline, the venation brown, the second submarginal cell quadrate; the first branch of the radius about one half the length of the second, the recurrent nervure not interstitial with the first transverse cubital nervure. Abdomen as long as the head and thorax together, oblong-oval, the first and second segments striated, the following smooth, polished, the third with a transverse crenate furrow.

Hab. St. Vincent.

Described from a single specimen, taken at 500 feet altitude.

Rhyssalus melleus, sp. $\mathrm{n}$.

o $q$. Length $1 \frac{1}{2}$ to 2 millim. ; ovipositor one third the length of the abdomen. Honey-yellow, the apical half of the abdomen brownish. Antennæ 15-jointed. Thorax with two distinct furrows, the scutellum crenate at base, the metathorax areolated. Wings hyaline, the venation pale brown, a yellowish spot at base of stigma; the first branch of the radius is a little shorter than the second, the recurrent nervure interstitial with the first transverse cubital nervure. Abdomen subpetiolate, smooth and polished, the first segment with lateral carinæ and slightly roughened. 
The male, or what is taken to be the male of this species, has 17-jointed antennæ, white legs, while the mesopleura, scutellum, metathorax, and base and apex of the abdomen are black or fuscous; the middle thoracic lobe has a central impressed line; while the wings are subhyaline with a yellowish spot across the base of the stigma and the first submarginal cell.

Hab. St. Vincent.

Described from 1 female, 4 male specimens.

RHYSSALUS BRUNNEIVENTRIS, sp. n.

o. Length 3 millim.; ovipositor longer than half the length of the abdomen. Pale ferruginous; a blotch beneath anterior wings, and the abdomen reddish brown. Antennæ multi-articulate, pale brown. Thorax faintly shagreened, indistinctly trilobed, pubescent ; the scutellum with two foveæ at base, separated by a raised line. Metathorax finely shagreened, not areolated. Wings subhyaline, the venation pale brownish; the first branch of radius not half the length of the second, the recurrent nervure not interstitial with the transverse cubital nervure but joins the cubitus some distance from its apex. Abdomen ovate, the length of the thorax, smooth and shining, the first segment finely sculptured.

Hab. St. Vincent.

Described from a single specimen. On account of the nonareolated metathorax this species does not agree with all the generic characters laid down for Rhyssalus, agreeing in this respect with the genus Colastes, Haliday; but as all of the other characters agree with Rhyssalus and not with Colastes, I have placed it in the former genus.

\section{Subfamily Agathidina.}

Agathis, Latreille.

Agathis RUbricinctus, sp. $\mathrm{n}$.

o 오. Length $3 \frac{1}{2}$ to 5 millim.; ovipositor longer than the body. Black, shining, punctate, covered with a cinereous pubescence, especially on the face, side of thorax, and the coxæ; the second abdominal segment with a broad reddish-yellow band. Head transverse rostriform, the vertex with a grooved line from the lateral ocellus to the margin of the eye; ocelli red. Antennæ black, involuted at tips. Thorax trilobed, punctate; scutellum 
with a crenate furrow at base ; metathorax rugose, with a central carina. Legs black, the anterior pair (except coxæ, trochanters, and two apical joints of tarsi) rufous; apical half of middle femora and base of their tibiæ rufous; a spot at base of posterior tibiæ, and all tibial spurs rufous. Wings hyaline, the venation brown-black. Abdomen black, polished, except the two basal segments which are finely shagreened, and the basal two-thirds of the second segment which is reddish yellow.

\section{Hab. St. Vincent.}

Described from 1 male, 14 female specimens.

\section{Agathis pectoralis, sp. n.}

$\delta$ ㅇ. Length 5 millim.; ovipositor half the length of body. Rufous; head, collar beneath, mesosternum, and legs black, the tips of anterior femora and their tarsi and the middle tarsi rufous. Thorax trilobed, impunctured; the scutellum with a deep depression across the base, separated into two parts by a raised line at the middle; metathorax rugose, with some delicate longitudinal keels. Wings fuliginous, with two or three white spots below the base of the stigma; areolet subquadrate. Abdomen elongate, smooth, polished, impunctured.

Hab. St. Viucent.

Described from 2 female, 12 male specimens.

\section{Microdus, Nees.}

Microdus Smithit, sp. n.

o ㅇ. Length 2 to $2 \frac{1}{5}$ millim.; ovipositor a little longer than abdomen. Black, polished; legs yellow; abdomen black, in male with a broad yellow band at the middle, in the female with a broad band before the middle and the apex yellow. Thorax trilobed, smooth, shining, pubescent; metathorax rugose, with iwo close central parallel keels on the disk. Wings hyaline, the venation brown. Abdomen, except the first segment, which is finely sculptured and grooved along the sides, smooth and polished.

Hab. St. Vincent.

Described from one male and one female.

Microdus unicinctus, sp. n.

․ . Length 3 millim.; ovipositor as long as the body. Black, polished, the face piceous, the second abdominal segment yellow ; 
four anterior legs honey-yellow ; the posterior legs black, their tibiæ with a broad white band at the middle; all tibial spurs white. Thorax trilobed, furrows deep; scutellum with a deep impressed line across the base; metathorax very finely shagreened, without carinæ. Wings hyaline, the venation brown, the areolet triangular. Abdomen about as long as the head and thorax together; except the first segment, which is finely shagreened, and the second, which is yellow, black, smooth and shining.

Hab. St. Vincent.

Described from a single specimen.

Microdus insularis, sp. n.

o 9 . Length 3 to 4 millim. ; ovipositor two thirds the length of body. Pale ferruginous; stemmaticum extending posteriorly on the occiput; longitudinal bands on lateral lobes of thorax, metathorax above, base and apex of abdomen, ovipositor, antenna, and posterior tibiæ and tarsi, except a pale streak on tibiæ above and an annulus at base, black. The furrows of thorax are crenate; the metathorax coarsely rugose, with a central furrow; the first abdominal segment keeled laterally and finely longitudinally striated basally two thirds of its length, while the posterior tibiæ are contracted at base. Wings hyaline, iridescent, the venation dark brown, the areolet triangular, open behind.

Hab. St. Vincent.

Described from one male and two female specimens.

\section{Orgilus, Haliday.}

Orgilus Pallides, sp. n.

ㅇ. Length $4 \frac{1}{2}$ millim.; ovipositor about as long as the abdomen. Honey-yellow; the antennæ above, middle tarsi, the second joint of posterior trochanters, spot at apex of femora, their tibiæ above and tarsi, fuscous or black. Thorax trilobed, the furrows crenate; the metathorax smooth, without carinæ. Wings greyish-hyaline, the venation brown; the marginal cell closed, extending nearly to the apex of the wing; the first cubital and first submarginal cells distinct, not confluent; the areolet triangular, the outer nervure pale.

Hab. St. Vincent.

Described from a single specimen. 


\section{Subfamily CaLyptina.}

\section{Calyptus, Hatiday.}

Calyptus thoracicus, sp. n.

ㅇ. Length 5 millim.; ovipositor longer than the body. Black, shining; thorax, excepting metathorax, and anterior coxæ and trochanters orange-red. Face with pale pubescence. Mandibles pale. Antennæ about 35 -jointed, attenuated and involuted at tips. Thorax with the parapsidal furrows broad and deep posteriorly; the scutellum convex, with two large foveæ at base, separated only by a carina. Metathorax rugose, coarsely areolated. Legs black, pubescent. Wings hyaline, the venation black. Abdomen with four segments, shining, the first and second striated; the first with two carinæ, the third and fourth smooth, polished.

Hab. St. Vincent.

Described from a single specimen, taken in August at an altitude of 500 feet. A most beautiful and easily recognized species, distinguished at once by its orange-red thorax.

Subfamily Blacina.

Blacus, Nees.

Blacus rubriceps, sp. $\mathrm{n}$.

o . Length $2 \frac{1}{2}$ millim. Black, polished; head red, ocelli black. Antennæ 26-jointed, black, the two basal joints pale. Thorax smooth, with two delicate furrows that converge and meet a little beyond the middle of the mesonotum ; the mesonotum is flattened posteriorly in front of the scutellum. Scutellum convex, with an impressed cross line at base. Mesopleura smooth, polished. Metathorax smooth, impunctured, with a central carina. Legs rufous. Wings hyaline, the venation brown-black; the recurrent nervure not interstitial with the transverse cubital nervure. Abdomen black, smooth, and polished.

Hab. St. Vincent.

Described from a single specimen taken in May.

\section{Ganychorus, Haliday.}

Ganychords collaris, sp. n.

q. Length 2 millim. Black, polished, the antennæ, collar, and legs reddish yellow, the posterior femora dusky toward tips. Antennæ 20-jointed, the last joint large, fusiform. Thorax smooth, with two distinct furrows; collar, sternum, and meta- 
thorax rugose, the latter with two large areas on disk, the surface of which is smooth. Wings greyish-hyaline, the venation pale brown; the recurrent nervure almost interstitial with the first transverse cubital nervure, the cubitus extending to the apical margin of the wing, the marginal cell therefore very large. Abdomen smooth, the first segment with lateral grooves, the second segment piceous; ovipositor about half the length of the abdomen.

Hab. St. Vincent.

Described from a single species.

\section{Subfamily LiOpHronin ж.}

\section{LiopHron, Nees.}

\section{LIOPHRON MINUTUs, sp. $\mathrm{n}$.}

ot 우. Length $1 \frac{1}{5}$ to $1 \frac{1}{2}$ millim. Black, highly polished; antennæ and legs in male yellowish; apical half of abdomen and antennæ in female piceous. Head transverse, the face with short, sparse, white hairs. Antennæ in female 20-jointed, in male 15-jointed. Thorax with the parapsides distinct, the scutellum foveated at base. Metathorax smooth, delicately areolated. Wings hyaline, the venation pale yellowish, the costa and stigma brown, the marginal cell about as long as the stigma; the first branch of the radius very short, the recurrent nervure joining the first submarginal cell. Abdomen in female smooth, the first segment with lateral grooved lines, the ovipositor very short; in male the first segment and the basal half of the second aciculated.

Hab. St. Vincent.

Described from one male and two female specimens.

\section{Subfamily Toxoneurin}

Toxoneura, Say.

Toxonedra ATricornis, sp. n.

0 ㅇ․ Length $3 \frac{1}{2}$ to 5 millim. Sanguineous to reddish yellow; the vertex of head and tip of abdomen dusky or black; antennæ, sheaths of ovipositor, tips of middle tibiæ, and posterior knees, tips of their tibiæ, and tarsi black or fuscous, the basal tarsal joint usually pale at base. Wings fuliginous. Sometimes the whole upper surface of the abdomen is dusky or brown, and occasionally it is entirely pale, concolorous with the thorax.

Hab. St. Vincent.

Described from 51 specimens. 


\section{Subfamily OpIIn ж.}

Gnamptodon, Haliday.

\section{Gramptodon? atricaudus, sp. n.}

ㅇ. Length $1 \frac{1}{2}$ millim.; ovipositor as long as the abdomen. Pale ferruginous, finely shagreened. Head transverse, the occiput margined. Antennæ slightly dusky towards tips. Thorax with two deep furrows, with sparse white hairs along the margins. Scutellum with a crenate furrow at base. Mesopleura with an oblique furrow below the middle. Metatborax finely rugose, indistinctly areolated. Wings hyaline, the venation pale; the first branch of radius very little shorter than the second, the recurrent nervure interstitial with the first transverse cubital nervure, the submedian cell slightly longer than the median. Abdomen elongate-oval, the first segment and basal two-thirds of the second finely rugose and striated, the second with a transverse furrow, the apex and the following segments smooth.

$H a b$. St. Vincent.

Described from two specimens.

This species does not agree exactly with the definition for the genus Gnamptodon, having the occiput margined and only one transverse suture on the second abdominal segment. In having the occiput margined it agrees with Ademon, Hal., but in all other characters it does not agree, and in my perplexity I have placed it doubtfully in Gnamptodon.

\section{Opius, Wesmael. \\ Table of Species.}

Mesonotum with furrows, or at least trilobed ...... Mesonotum without furrows, not trilobed.

Recurrent nervure interstitial with the first transverse cubital nervure, or joining the first submarginal cell ......................

Recurrent nervure not interstitial, or joining an angle in the second submarginal cell.

Black, legs pale; the third abdominal segment longer than the first ............... Oalvini.

Honey-yellow, the head black; second and third abdominal segments equal, shorter than the first ........................ O. melanocephalus.

Entirely honey-yellow; second abdominal segment short, with oblique foveæ at base .... O. insularis. 
2. Black; second abdominal segment with a yellow

band, longer than the first ............ O. unifasciatus.

Honey-yellow or pale ferruginous, the tip of the

abdomen sometimes very dusky.

Second abdominal segment not longer than the first; the recurrent nervure interstitial .... O. interstitialis.

Second abdominal segment shorter than the first;

the recurrent nervure rejected $\ldots \ldots \ldots \ldots .0$. rejectus.

3. Pale ferruginous or honey-yellow, head and apex of abdomen black or brown.

Antennæ not ringed with white; recurrent nervure not interstitial $\ldots \ldots \ldots \ldots \ldots \ldots \ldots \ldots$.

O. atriceps.

Antennæ ringed with white; recurrent nervure interstitial $\ldots \ldots \ldots \ldots \ldots \ldots \ldots \ldots \ldots$.

O. annulicornis.

\section{Opius Salvini, sp. n.}

o ㅇ. Length $1 \frac{1}{2}$ to 2 millim.; ovipositor much longer than the abdomen. Black, shining, impunctured, rarely with the disk of thorax, metathorax, and a spot on second abdominal segment brown; legs and two basal joints of antennæ honey-yellow or reddish yellow, the rest of the antennæ varies from brown to black. In the female the antennæ are 23 -jointed, in the male 21- to 26-jointed. Thorax smooth, without furrows. Scutellum foveated at base. Mesopleura with a crenate furrow. Metathorax rugose. Wings hyaline, iridescent, the venation dark brown; the first branch of the radius very short, the recurrent nervure not interstitial, joining an angle in the second submarginal cell. Abdomen oval, in the female the first and second segments about equal, the third the largest; in the male the second segment is the longest; the third segment is roughened, the following smooth, polished.

Hab. St. Vincent.

Described from 30 specimens.

\section{Opius melanocephalus, $\mathrm{sp} \cdot \mathrm{n}$.}

o 9 . Length 1 to 2 millim.; ovipositor less than one third the length of the abdomen. Honey-yellow, smooth, impunctured; the head always black with the face sometimes pale, and sometimes in the male the abdomen, except the base, is sometimes brown or black. Antennæ in female 24-jointed, in male 22- or 27-jointed, variable from a honey-yellow to brown. Thorax smooth, without furrows; the scutellum foveated at base; the mesopleura with a crenate furrow, the metathorax areolated or 
rugose. Wings greyish-hyaline, the venation brown; the first branch of the radius very short, the recurrent nervure not interstitial, joining an angle in the second submarginal cell. Abdomen oval, the second and third segments equal, shorter than the first, the first carinated and with a groove at the sides; rest of the abdomen smooth, polished.

Hab. St. Vincent.

Described from 20 specimens.

Opius insularis, sp. n.

o 9 . Length 1 to 2 millim.; ovipositor short. Entirely honeyyellow, smooth and polished; the male abdomen black toward apex. Antennæ in female 19- to 26-jointed, black, the two basal joints pale; in male 24- to 27 -jointed. Thorax smooth, without furrows, the scutellum foveated at base, the mesopleura with a crenate furrow, metathorax rugose or areolated. Wings hyaline, the venation pale brown; the first branch of radius very short, the recurrent nervure joining an angle in the second submarginal cell. Abdomen oval, the first segment roughened, with grooved lines at sides, the following segments smooth, polished, the second segment shorter than the first, with two oblique foveæ at base.

Hab. St. Vincent.

Described from 11 specimens.

Opius unifasciatus, sp. n.

ot. Length $2 \frac{1}{2}$ millim. Black, polished; the basal two-thirds of second abdominal segment, two basal joints of antennæ, and legs yellow. Antennæ 29-jointed. Thorax smooth, polished, without furrows, the scutellum with a crenate furrow along the base, a crenate furrow on the mesopleura, and the metathorax coarsely rugose. Wings hyaline, iridescent, the venation brown; the first branch of the radius short, the recurrent nervure interstitial with the first transverse cubital nervure. Abdomen oval, smooth, polished, the second segment longer than the first, striated, furrowed at sides.

Hab. St. Vincent.

Described from a single specimen.

OpiUs interstitialis, sp. $\mathrm{n}$.

$\delta$. . Length 1 to 2 millim.; ovipositor very short, scarcely exserted. Entirely honey-yellow, seldom with the tip of the 
abdomen dusky. Antennæ, except the two basal joints, fuscous or black. Thorax polished, without furrows, the scutellum with a crenate furrow at base, mesopleura with a crenate furrow, and the metathorax finely rugose and areolated. Wings hyaline, the venation fuscous or brown; the recurrent nervure insterstitial with the first transverse cubital nervure, the submedian cell slightly longer than the median. Abdomen oval, polished, the first segment longer than the second, sculptured with furrows along the sides, the second with two oblique foveæ at base.

Hab. St. Vincent.

Described from 51 specimens.

Opius ReJeCtus, sp. n.

o 9 . Length $1 \frac{1}{2}$ to 2 millim.; ovipositor about one third the length of the abdomen. Entirely honey-yellow, the antennæ alone black. Antennæ in female 27-jointed, in male 21-jointed. Thorax smooth, polished, without furrows, the mesopleura without a furrow, and the metathorax smooth, not areolated. Wings greyish-hyaline, the venation brown; the first branch of the radius longer than in the foregoing species, while the recurrent nervure joins the first submarginal cell. Abdomen smooth, polished, the first segment longer than the second, with furrows along the sides, but the disk smooth.

Hab. St. Vincent.

Described from two specimens, a male and a female.

OpIUS ATRICEl s, sp. n.

ot. Length $1 \frac{1}{2}$ to $1 \frac{4}{5}$ millim. Honey-yellow; head and apical half of abdomen, or at least the tip, black or brown, variable, the face usually pale. Antennæ fuscous, pale toward base. Thorax smooth, with distinct parapsidal furrows; the scutellum foveated at base, or areolated. Legs yellowish white. Wings subhyaline, the venation dark brown; the recurrent nervure not interstitial, joining the first submarginal cell. Abdomen ovate, smooth, the first segment the longest, striated.

Hab. St. Vincent.

Described from three specimens.

OpIUS ANNULICORNIS, sp. n.

o . . Length 2 millim.; ovipositor short. Honey-yellow; the head and apex of abdomen brownish or black. Antennæ black, yellow toward base, with a white annulus beyond the 
middle. Thorax smooth, with distinct parapsidal furrows, the scutellum with a crenate furrow across the base, a crenate furrow on the mesopleura, and the metathorax rugose or areolated. Legs yellowish white. Wings hyaline, the venation brown, the recurrent nervure interstitial. Abdomen oblong-ovate, smooth, shining, the first segment the longest, striated.

Hab. St. Vincent.

Described from three specimens.

Diachasma, Förster.

Diachasma Pilosipes, sp. n.

o 우. Length 2 millim. Pale honey-yellow; the eyes large, round, brown. Legs whitish, pilose. Thorax microscopically shagreened, without furrows, the disk somewhat flat. Scutellum with a fovea at base, the bottom with a central raised line. Mesopleura smooth, without a furrow. Metathorax smooth, with a central carina. Abdomen linear, smooth, the first segment the longest. Wings hyaline, the venation pale or yellowish, the recurrent nervure interstitial with the first transverse cubital nervure.

Hab. St. Vincent.

Described from three specimens.

Subfamily Alysinæe.

Phenocarpa, Förster.

Phenocarpa pleuralis, sp. $n$.

․ Length $1 \frac{4}{5}$ millim. Head, mesopleura, and disk of abdomen black; thorax and abdomen, with the exceptions noted, honeyyellow; legs white. Wings hyaline, the venation pale brown. Metathorax areolated. First abdominal segment a little wider than long, with two delicate carinæ on disk; rest of the abdomen smooth, polished; the ovipositor very short, scarcely projecting. Hab. St. Vincent.

Described from a single specimen, having the antennæ broken.

Subfamily ApHIDIIN ж.

Lysiphlebus, Förster.

Lysiphlebus Meridionalis, sp. $\mathrm{n}$.

ㅇ. Length $1 \frac{1}{2}$ millim. Black, polished; legs, mandibles, and petiole of abdomen pale brown. Antennæ 13-jointed, black, the

LINN. JOURN.-ZOOLOGY, VOL. XXV. 
two basal joints pale beneath, the second with a pale ring at apex; funicle-joints about two and a half times as long as thick, the last a little longer than the first. Wings hyaline, the venation pale brown, the second branch of the stigmal vein longer than the transverse cubitus.

Hab. St. Vincent.

Described from a single specimen taken at 1500 feet altitude.

\section{Family ICHNEUMONIDÆ.}

\section{Subfamily CrYptina.}

\section{Mesostenus, Grav.}

\section{Mesostenus insularis, sp. n.}

o $q$. Length 5 to 10 millim.; ovipositor 3 to $3 \frac{1}{2}$ millim. Head, antennæ, thorax, and ovipositor black; the orbits broadly, cheeks, face below antennæ, clypeus, labrum, spot at base of mandibles, palpi, a broad annulus on antennæ, upper margin of collar, spot before front coxæ, anterior and middle coxæ and trochanters, spot on posterior coxæ behind at base, tegulæ, spot below, second joint of posterior tarsi, and scutellum white. Legs and abdomen rufous, the tarsi black or fuscous. Head smooth, impunctured, with a central carina from front ocellus. Thorax shining, sparsely punctate, the parapsidal furrows distinct, crenulated, the middle lobe with longitudinal striæ posteriorly; metathorax with two transverse keels, the posterior angles slightly compressedly toothed, the enclosed space at base smooth, the space between the first and second transverse keels coarsely longitudinally striated, the posterior face very coarsely rugose, metapleura with coarse transverse striæ. The mesopleura below and the metathorax more or less densely covered with a glittering white, appressed pubescence. Wings hyaline, the venation piceous, the areolet quadrate. Abdomen with three basal segments, finely microscopically punctulate. In the male the annulus on the antennæ is narrower, the white spot at base of posterior coxæ wanting; the second, third, and fourth joints of posterior tibiæ are usually white, although sometimes only the second joint is white or the first partially white, and in a single case the tarsi are wholly dusky. The metathorax is more rounded behind than in the female, the latera? angles not at all toothed, while the abdomen is smooth, impunctured.

Hab. St. Vincent. 
Described from a large series, 21 specimens, taken from 500 to 1500 feet altitude. It is very variable in size, in the width of the annulus on antennæ, and in the white on the posterior tarsi.

\section{Subfamily OpHIONINæ.}

\section{Nototrachys, Marshall.}

Nototrachys Niger, sp. n.

ot 우. Length $8 \frac{1}{2}$ to 9 millim. Entirely black, except a lateral spot on the fourth abdominal segment, and the second, third, and fourth ventral segments, anterior legs (except coxæ and trochanters), and tibial spurs, which are rufous; the female antennæ are annulated with white. Head, before, rugose, with a central carina extending from the front ocellus; mesonotum with shallow, crenulated furrows, the middle lobe rugose ; metathorax reticulately rugose, with two semicircular areas at base. Wings hyaline, the tips slightly smoky, the venation brownblack.

Hab. St. Vincent.

Described from one male and one female. The male was taken in a dry scrubby forest near Cumberland, seaward, Sept. 30th, at an altitude of 500 feet; the female at 2000 feet altitude.

Nototrachys minimus, sp. n.

o 9 . Length $4 \frac{1}{2}$ to 5 millim. Differs from $N$. niger in its smaller size, the frons with a white orbital spot, in both sexes opposite the antennæ; the anterior and middle legs, including coxæ, and the whole side of the fourth abdominal segment rufous; the mesonotum punctate; the metathorax with two transverse carinæ; otherwise in the white annulus on the antennæ and in its wing-characters it agrees with $N$. niger.

Hab. St. Vincent.

Described from one female and two male specimens. The white orbital spot and the rufous anterior and raiddle legs readily distinguish the species.

\section{Campoplex, Grav.}

Campoplex meridionalis, sp. $\mathrm{n}$.

o 9 . Length $6 \frac{1}{2}$ to $7 \frac{1}{2}$ millim. Black, covered with a fine, sericeous pubescence ; mandibles, palpi, scape beneath, and anterior and middle coxæ and trochanters yellowish white, the coxæ 
with a spot before ; legs rufous, the middle tarsi fuscous, posterior legs, including coxæ, black; claws pectinated. Antennæ nearly as long as the body, black. Thorax closely punctulate; metathorax areolated rugose, the middle area with transverse raised lines. Abdomen one and a half times as long as the head and thorax together, compressed, black, the sides of segments 4, 5, and 6 and the venter rufous; the petiole longer than the second segment, swollen at tip, smooth, shining, and impunctured, the following segments closely, finely, microscopically punctate. Wings subhyaline, the venation black, the areolet small, petiolate.

The female differs from the male only in having an ovipositor 3 millim. long, and in that the apical half of the abdomen, beginning from the middle of the third segment, is entirely rufous. The wing-areolet is also more distinct.

Hab. St. Vincent.

Described from 2 female, 6 male specimens, taken on west slope, Gonfrière, Sept. 23, in a forest at an altitude of 1800 feet.

\section{Cremastus, Grav.}

\section{Cremastus (?) insularis, sp. n.}

․ Length 5 millim.; ovipositor 2 millim. Honey-yellow; antennæ except scape, spot at base of metathorax, base and tip of posterior tibiæ, apex of abdomen, first, second, and base of third abdominal segments black; the sutures of the first, second, third, and fourth antennal joints pale. Eyes very large, oval, occupying the whole side of the head, and extending to base of mandibles. Thorax trilobed, middle lobe prominent. Metathorax sloping posteriorly, areolated. Wings hyaline, iridescent, the venation dark brown, areolet oblique, petiolated.

Hab. St. Vincent.

Described from a single specimen, taken in a damp forest in Petite Bordelle Valley, Oct. 23. This is not a true Cremastus.

\section{Mesochords, Grav.}

\section{Mesochords anndlitarsis, sp. n.}

o. Length $2 \frac{1}{2}$ millim. Yellowish white ; lateral lobes of mesothorax, metathorax, annulus at base and apex of posterior femora, and the apex of the first, second, third, and fourth joints of their tarsi, and the last tarsal joint black. Abdomen above (except the apical two-thirds of the second and the basal half of third segment, which are luteous), black, the apex paler; middle lobe 
of the thorax fuscous. Antennæ 24-jointed, pale, toward the apex fuscous. Wings hyaline, the venation pale, the cubital vein extending from the areolet to the apical margin of wing entirely wanting.

Hab. St. Vincent.

Described from a single specimen taken at " sea-level." The species comes nearest to $M$. americanus, Cr., than to any other of the North-American species; but can be distinguished from it and other closely allied forms by the annulations on the posterior tarsal joints and the absence of the cubital vein.

\section{Subfamily Tryphoninæ.}

\section{Exоchus, Grav.}

Exochus tegularis, sp. n.

ऽ. Length 5 millim. Honey-yellow, antennæ, a spot on occiput extending forwards and enclosing ocelli, tegulæ, broad band on middle thoracic lobe, spot cn the lateral lobes, metathorax above, spot on posterior coxæ beneath, extreme base of posterior tibiæ, and the abdomen above black; venter and sides of second, third and fourth, fifth and sixth abdominal segments boney-yellow, those on the fourth and fifth meeting above and forming a band. Antennæ 30-jointed, straight. Metathorax distinctly areolated. Wings hyaline, the areolet entirely wanting.

Hab. St. Vincent.

Described from a single specimen, and seems to come nearest to the Cuban $E$. validus, Cr.

\section{Orthocentrus, Grav.}

\section{* Areolet wanting.}

Orthocentrus variabilis, sp. $n$.

of ․ Length 2 to $3 \frac{1}{2}$ millim. Black, polished, the tace pale, rarely in male entirely black; mandibles, palpi, and legs yellowish white or honey-yellow; in one specimen only the posterior coxæ are black, the femora brown, in another the posterior femora and coxæ are brown; sometimes the posterior femora and the tips of the tibiæ are brown. Usually the thorax and abdomen are entirely black, but two or three specimens have the mesonotum pale, and sometimes a pale streak across the second abdominal segment. The antennæ are usually 26-jointed in the male, 22- or 24-jointed in the female, black or dusky, 
always pale toward base. The metathorax is smooth, polished, impunctured, not areolated, but with delicate side-keels. Abdomen polished, the venter always pale, the first segment with a depression towards the tip and with some slight raised lines. Wings hyaline, the venation brown, the stigma large, triangular; the areolet entirely absent.

\section{Hab. St. Vincent.}

Described from 10 specimens, taken at an altitude of from 500 to 1000 feet. There may be more than one species; but as the specimens at hand are so few and badly mounted, I must leave the question to be settled by future investigators.

\section{** Areolet present, pentagonal.}

\section{Orthocentrus insularis, $\mathrm{sp}$. $\mathrm{n}$.}

o. Length 3 to 4 millim. Honey-yellow or luteous; stemmaticum, dot behind cheeks, sides of mesonotum, metathorax and abdomen (except apical half of the second, the whole of third, the base of the fourth and the apical segments) black. The posterior knees, tip of tibiæ, and the extreme tip of the tarsal joints fuscous; rest of the legs white. Antennæ 41-jointed, pale, longer than the body, curled and fuscous at tips. Metathorax rather long, the disk smooth, with two close, central, subparallel, longitudinal carinæ extending from base to apex; the metapleura are bounded by a keel, and the space behind the spiracles is a little roughened and almost enclosed by a carina between the central longitudinal keel and the metapleural keel. Wings hyaline, the venation pale brown, the stigma triangular; the areolet rather large, pentagonal. The two basal abdominal segments are rough, the first with two longitudinal carinæ above, the second segment depressed at the middle, the following all smooth, but more or less punctate.

Hab. St. Vincent.

Described from 7 specimens, taken at an altitude of from 1000 to 1500 feet.

\section{Subfamily Pimpline. \\ Lampronota, Curtis.}

Lampronota albomaculata, sp. n.

․ Length $7 \frac{1}{2}$ millim. ; ovipositor 8 millim. Black; abdomen and legs, with the exceptions mentioned below, rufous; face, orbits, cheeks, clypeus, mandibles, palpi, two stripes on meso- 
notum, seutellum, postscutellum, spot below tegulæ, posterior tegulæ, two large spots beneath, a longitudinal band on mesopleura, prosternum and collar, anterior coxæ, two spots on mesosternum before the middle coxæ, middle coxæ except a black spot behind, posterior coxæ except a large spot before and behind, and the metapleura, all white. Head transverse, impunctured, shining; ocelli large, red; eyes large, oval, dark brown. Thorax without furrows, smooth, shining, with some sparse punctures on the disk and on the scutellum; metathorax sloping off gradually posteriorly, transversely rugulose, without carinæ. Legs rufous, coxæ white, the middle pair with a black spot before and behind, the first joint of middle and posterior trochanters black, anterior and middle tarsi dark fuscous, approaching black, the middle tibiæ more or less fuscous, extreme tip of posterior femora and their tibiæ and tarsi wholly black, tibial spurs white. Wings hyaline, iridescent, the venation piceous black. Abdomen with the basal and second segments black or dusky at base and apex, with a dusky blotch on the side of the third segment.

Hab. St. Vincent.

Described from a single specimen, taken at an altitude of 2500 feet.

\section{Family CHALCIDIDÆ.}

Subfamily Eurytominæ.

Ashmeadia, Howard.

$$
\text { (Rileya, Ashmead.) }
$$

Table of Species.

Pale or brownish-yellow species $\ldots \ldots \ldots \ldots$.

Black species.

All coxæ black.

Femora toward base brown, rest of legs and the antennal scape brownish yellow.

Antennæ in both sexes subclavate, the funicle-joints transverse ........

Legs, except articulations and the tarsi, wholly black.

Antennæ in male with the funicle-joints strongly pedicellate-moniliform, with sparse whorls of long hairs; female

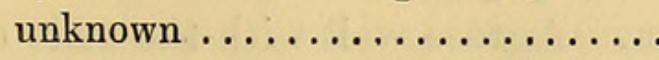

A. insularis, sp. $\mathrm{n}$.

A. abnormicornis, sp. $\mathbf{n}$. 
All coxæ pale.

Legs wholly brownish yellow; antennæ in male subclavate, the joints transverse; female unknown ...............

2. Wholly brownish yellow.

A. pallidipes, sp. n.

Club of stigmal vein very large, circular; dorsum of metanotum black; antennæ in female subclavate, brown; male unknown ......................

Yellowish white, with brownish and black A. megastigma, sp. $\mathrm{n}$. markings; the club of the stigmal vein normal.

Middle lobe of mesonotum, the scutellum and axillæ, except margins, and the metanotum black; occiput and vertex, except orbits and a streak before and behind the ocelli, pronotum anteriorly and three or four fasciæ above, disks of abdominal segments, and venter brown; the 3rd abdominal segment with a whitish fascia along the sides curving upwards and extending along the apical margin ....................

A. pulchra, sp. n.

Ashmeadia insularis, sp. $n$.

․ Length 3 millim. Robust, black, shagreened; scape and legs, except coxæ and the femora at base, brownish yellow; flagellum subclavate, brown-black, the joints transverse ; suture and margins between abdominal segments 5 and 6 piceous; scutellum with some shallow umbilicate punctures; metathorax rugose. Wings hyaline, the venation yellowish, the marginal vein very long, about two thirds the length of the submarginal, or three or more times longer than the stigmal. Abdomen subpetiolate, conic-ovate, a little longer than the head and thorax united, shagreened.

The male is only 2 millim. long and, except in its smaller size, a more flattened, petiolate abdomen (the petiole short and stout), and pale brown antennæ, it agrees in all respects with the female.

Hab. St. Vincent.

Described from one male and one female.

Ashmeadia pallidipes, sp. $\mathrm{n}$.

0 . Length 1.8 millim. Agrees well with the male of $A$. insu- 
laris, except the legs, including all coxæ, are uniformly brownish yellow, the scutellum exhibits no umbilicate punctures, the petiole of abdomen is more slender and longer, being about $2 \frac{1}{2}$ times as long as thick, while the venter is piceous.

Hab. St. Vincent.

Described from one male specimen.

\section{Ashmeadia abNoRMICORNIS, sp.n.}

o . Length 1.5 millim. Wholly black, except the articulations of legs and the tarsi, which are honey-yellow. Antennæ with the funicle-joints round and strongly pedicellated at apex, with whorls of whitish hairs, the club being 3-jointed. Wings clear hyaline, the marginal vein long and slender, more than three times the length of the stigmal vein.

Hab. St. Vincent.

Described from a single specimen.

The peculiarity of the antennæ renders the species easy of recognition, and will probably warrant, when the female is discovered, the creation of a new genus for its reception.

\section{Ashmeadia megastigma, sp. n.}

q. Length 2 millim. Wholly brownish yellow, the metanotum and sheaths of ovipositor black; flagellum pale brownish, the joints transverse, pubescent; wings hyaline, the stigmal vein terminating in a large circular stigma, the marginal vein less than three times the length of the stigmal.

Hab. St. Vincent.

Described from one specimen.

The large, circular stigma, as in the Torymid genus Megastigma, at once distinguishes the species.

\section{Ashmeadia pulchra, sp. n.}

o 9 . Length 1.5 to 2 millim. Yellowish white; vertex of head and the occiput, except a spot before and behind ocelli and the orbits, the pronotum anteriorly and three or four fasciæ on its disk, abdominal segments above, and the venter brownish; middle lobe of mesonotum, scutellum and axillæ, except margins, and the metanotum black; the third abdominal segment has a long white fascia at sides that curves upwards and extends along the apical margin of the segment; scape of antennæ white; flagellum subclavate, brown, the joints transverse. Wings 
hyaline, the venation pale, the marginal vein three times as long as the stigmal.

The male is the smaller, and differs only in having the abdomen less pointed, and with the sides, apex, and the venter wholly white.

Hab. St. Vincent.

Described from 15 female and 4 male specimens.

This is the prettiest species yet discovered in the genus, and resembles somewhat a pale species, undescribed, known to me from South Florida.

\section{Systole, Walker.}

(?) Systole ABNormis, sp. n.

․ Length 1.6 millim. Black, smooth, impunctate, sparsely covered with whitish pubescence, or the head and thorax at the most feebly shagreened. Abdomen conic-ovate, highly polished, the fifth segment very long. Antennæ subclavate, sparsely pubescent, the pedicel much larger than the first funicle-joint, the funicle-joints a little longer than wide. Wings hyaline, the venation pale yellowish, the marginal vein very long, three times as long as the stigmal. Antennæ and legs, including coxæ, pale yellowish, pubescent.

Hab. St. Vincent.

Described from three female specimens. The venation and the relative length of the abdominal segments will exclude this species from Systole, although otherwise, in sculpture and in antennal characters, it agrees with the definition of the genus. It agrees in venation with Ashmeadia, but otherwise its habitus is wholly different.

\section{Bephrata, Cameron.}

Bephrata cultriformis, sp. $\mathrm{n}$.

․ Length 5 millim. Brownish yellow or yellowish, except as follows:- flagellum, stemmaticum, median stripe on pronotum, middle lobe of mesonotum, and rest of thorax, except axillæ and parapsides, black; hind tibiæ, large spots on the dorsum of abdominal segments extending into a triangular shape at the sides, and the terminal segment black. The antennæ are filiform, the joints elongate, cylindrical, the first funicle-joint as long as the scape. The head is much broader than the thorax. Wings greyish hyaline, the venation brown-black; the marginal vein is 
nearly twice as long as the stigmal; while the abdomen is strongly compressed, knife-shaped, as in the Cynipid genus 1balia, and almost two and a half times as long as the head and thorax combined.

Hab. St. Vincent.

Described from a single specimen. The species is remarkable for the cultriform abdomen.

\section{Decatomidea, Ashmead.}

Decatomidea pallidicornis, sp. $n$.

ㅇ. Length $2 \cdot 1$ millim. Black, strongly confluently punctate, with a whitish pubescence; antennæ, tegulæ, and legs, except coxæ, pale brownish yellow; the coxæ black, scaly punctate, pubescent; posterior tibiæ with stiff bristles behind; funiclejoints a little longer than wide, the first the longest joint; pedicel brownish above, parapsidal furrows indicated only anteriorly, obliterated posteriorly ; pleura striate. Wings clear hyaline, the venation pallid or whitish, the marginal vein about one and a half times as long as the stigmal, while the postmarginal is only a little longer than the stigmal. Abdomen subglobose, with a reticulate or scaly punctuation at sides and beneath, almost smooth along the dorsum, the petiole very short; the 4 th segment the longest, three times as long as the 3rd segment above.

The male agrees with the female except in having the flagellum black, the joints being bearded with long hairs, the first funiclejoint longer than half the length of the scape and stouter than any of the following, the funicle-joints 2,3 , and 4 being contracted at tips. Mandibles and palpi pale, the outer margin of mandibles being brown.

Hab. St. Vincent.

Described from one male and one female.

Eurytoma, Illiger.

Table of Species.

Species more or less brownish yellow .......

Species black.

Coxæ pale.

Scape and legs pale brownish yellow; venter piceous (오. ...........

Coxæ black.

Scape and legs pale brownish yellow.

Funicle-joints 1 to 5 long and strongly 
pedicellate at apex, each joint bearing two whorls of whitish hairs; no pale spot on pronotum; tegulæ pale; petiole one half longer than hind coxæ, closely punctate. $\left(\delta^{\tau}\right) \ldots .$. Hind femora, except at tips, black.

Funicle-joints 1 to 5 pedicellate, with two whorls of long hairs; a yellow spot at the anterior angle of pronotum; tegulæ black; petiole longer than hind coxæ, smooth towards apex and along the sides. $\left(\sigma^{*}\right) \ldots \ldots \ldots$

2. Brownish yellow.

E. insularis, sp. n.

E. peraffinis, sp. n.

Median stripe on pronotum, middle lobe of mesonotum and metanotum, except the angles, dusky or black.

Petiole in both sexes long, slender, black; body of abdomen above with black markings; 3rd ventral segment with a black spot.

ㅇ. Flagellum black, the joints twice as long as thick ..............

ऽ. Antennæ wholly black, except someE. maculiventris, sp. n. times the scape at base or beneath; funicle-joints much elongated, pedicellate at apex, with two distinct widely separated whorls of long hairs, the first joint being nearly as long as the scape.............

E. maculiventris.

\section{Eurytoma insularis, sp. n.}

đ 우. Length from 2 to 3 millim. Black, umbilicate-punctate, with a sparse glittering white pubescence. In the female the scape, tegulæ, and legs, including coxæ, are wholly pale brownish yellow; venter piceous or rufous; the pedicel and flagellum brown-black ; first funicle-joint one half longer than the second, the joints beyond gradually subequal, the last being not, or scarcely, longer than wide; club 3-jointed. Wings hyaline, the venation pallid yellow, the marginal vein being about one and a half times as long as the stigmal, the postmarginal scarcely longer than the stigmal. Abdomen conic-ovate, not quite as long as the thorax, with a very short rugose petiole, the rest of abdomen being smooth and highly polished, the 5th segment 
three times as long as the 4th, the following with sparse white hairs.

The male agrees with the female, except in having the coxæ black; flagellum very long, black, the funicle-joints 1 to 5 strongly pedicellate at apex, with two whorls of long white hairs, the first joint being the longest, fully two thirds the length of the scape; joints 8 and 9 separated by a constriction; petiole long, one half longer than the hind coxæ, uniformly and confluently punctate; body of abdomen smooth, polished, the third segment (excluding the petiole) the longest, fully twice as long as the second, the first longer than the second, with a large fovea at base above.

Hab. St. Vincent.

Described from 1 female and 8 male specimens.

Eurtioma peraffinis, sp. n.

o. Length 2.5 millim. Closely allied to $E$. insularis, but differs as follows:-The scape is pale only at base beneath; the pronotum has a yellow spot at the angles anteriorly, and easily overlooked if the head is thrown back on the collar; hind femora, except at tips, black; petiole much longer than the hind coxæ, smooth towards apex and along the sides, finely punctate towards base; while the third body-segment of the abdomen is more than twice as long as the second.

A female specimen of what is undoubtedly the opposite sex of this species, without a head, agrees in all essential characters with the male, except that all the femora toward base are more or less dusky or black; as in the male, it shows a pale spot on the angles of the pronotum anteriorly; the abdomen is shaped much as in the female insularis, only it is black, except just at base beneath, and shows a very delicate wavy lined sculpture along the sides under a strong lens.

Hab. St. Vincent.

Described from one male and one female.

Distinguished by the pronotal spot, more frequently met with in the genus Isosoma.

Eurytoma maculiventris, sp. $n$.

$\delta$. Length 2.5 to 3 millim. Brownish yellow; teeth of mandibles 4-dentate; flagellum, stemmaticum (especially in the male), median stripe on collar, middle lobe of mesonotum, meta- 
notum (except a large spot at posterior angles and the pleura), the petiole, markings on disks of abdominal segments $2,3,4$, and 5 , and the base of ventral segment 2 , black or dusky. Wings hyaline, the venation pallid, the marginal vein about twice as long as the stigmal. Antennæ in female filiform, the funicle-joints about twice as long as thick, the first the longest; hind tibiæ with stiff bristles behind. Abdomen conic-ovate, compressed, pointed at apex, the petiole as long as the hind coxæ, the fourth body-segment two and a half times as long as the third.

In the male the antennæ are wholly black, except the scape at base or beneath, the funicle-joints all elongated, pedicellate at apex, with two whorls of widely separated long hairs, the first joint being as long as the scape; abdomen ovate, compressed, the petiole long, slender, the third and fourth body-segments nearly of an equal length; spiracles of the sixth segment surrounded by black.

Hab. St. Vincent.

Described from 4 female and 3 male specimens.

\section{Chrysidea, Spinola.}

This genus seems to differ from Eurytoma only in its strongly metallic colour, and unless structural characters are discovered to separate the two, it cannot be accepted as a valid genus.

The genus seems peculiar to the South-American fauna, but a single male specimen being in the collection from St. Vincent. The genus is placed in the family Perilampidæ by Westwood and Spinola.

\section{Chrysidea aurata, sp. n.}

o. Length 2 millim. Head, thorax, and coxæ golden green, strongly coarsely confluently punctate; scape at base and legs, except the coxæ and hind femora, brownish yellow; rest of antennx, hind femora, except tips, and the abdomen black, the latter with an æneous tinge at the sides of the 4th segment. Antennæ very long, the funicle-joints all lengthened, pedicellate at apex, and with 2 whorls of long white hairs, each joint being also slightly constricted at the middle between the whorled hairs, the first joint being almost as long as the scape. Wings hyaline, the venation pale brownish yellow, the marginal vein about twice the length of the stigmal. Abdomen with a long petiole, which is thicker at base than at apex; body of abdomen pear-shaped, the 
first segment more than twice the length of the second, the third fully four times as long as the second, while the following are very short, slightly withdrawn within the third.

Hab. St. Vincent.

Described from a single male specimen.

\section{Edrytomocharis, Ashmead.}

\section{Eurftomocharis minima, sp. n.}

o 9 . Length 1.6 millim. Black, umbilicate-punctate, with a sparse whitish pubescence; antennæ and legs, except coxæ, reddish yellow, the hind tibiæ behind with several long bristlelike spines. Eyes large, almost circular. Pedicel stouter and longer than the first funicle-joint, the scape being as long as the pedicel and first two funicle-joints combined; flagellum subclavate, the funicle-joints oblong-oval, the club fusiform, 3-jointed, much stouter than the funicle. Wings hyaline, the venation pale yellowish, the marginal vein nearly twice the length of the stigmal, the latter curving upwards, the postmarginal very little longer than the stigmal. Abdomen conic-ovate, produced into a conic point at apex, nearly sessile, with an alutaceous punctuation at the sides, the 2nd segment (1st body-segment) being a little longer than either the $3 r d$ or 4 th, which are about equal, the 5th longer than all the preceding united.

The male differs from the female only in its antennal and abdominal characters :-The antennæ (excluding ring-joints) are 8-jointed, the four funicle-joints nearly of an equal length, strongly pedicellate at apex, with long bristly hairs, the scape being no longer than the pedicel and firsi funicle-joint united; the body of abdomen is globose, with the 3rd segment the longest, it being as long as the 1st and 2nd united, and encloses the following; while the petiole is almost as long as the body of the abdomen, shining, and almost smooth. In this sex the hind femora have a dusky or black cloud toward the apex.

Hab. St. Vincent.

Described from two female and two male specimens.

\section{Isosoma, Walker.}

ISOSOMA HETEROMERA, sp. n.

o 9 . Length 3 to 4 millim. Black, the head and thorax umbilicate-punctate, with a sparse white pubescence; scape and legs, except hind coxæ, reddish yellow; flagellum brownish, 
pubescent; the first funicle-joint is the longest, the following joints being gradually subequal, the last scarcely longer than wide, while all are rounded at base and apex; club 3-jointed. Wings hyaline, the tegulæ small, yellowish, the venation pailid, the marginal vein about one and a half times as long as the stigmal. Abdomen elongate conic, highly polished, pubescent at apex, as long as the head and thorax combined; the segments unequal in length, the 1st and 3rd body-segments almost equal, the 2nd slightly shorter, the 4 th as long as all the preceding united, the 5 th a little shorter than the $3 \mathrm{rd}$, the 6 th one half longer than the 5 th.

The male differs from the female as follows:-The funiclejoints are strongly pedicellate at apex, verticilately pilose, the scape being scarcely as long as the small pedicel and first funiclejoint united; body of abdomen ovate, subcompressed, the 3rd segment being a little longer than 1 and 2 united, 4 and 5 subequal, the 5 th the longer.

Hab. St. Vincent.

Described from two females and one male.

Subfamily Toryminж.

Calyostichus, Mayr.

Calyostichus auratus, sp. n.

$0^{\pi}$. Length 1.8 millim. Golden-green, shagreened, and with a few scattered punctures over the surface, sparsely pubescent; antennæ and legs pale brownish yellow. Abdomen broadly oval, much depressed or very flat, pale yellowish, except a dusky spot at base and apex, the segments nearly of an equal length, the first segment foveated at base by the short thick petiole. Antennæ inserted a little below the middle of the face, the scape rather short, not reaching to the ocelli, the pedicel large, stout; funicle-joints increasing in width toward the club, the joints transverse. Thorax rather long; the pronotum large, trapezoidal, longer than the mesonotum; mesonotum with two distinct furrows; scutellum longer than wide, convex behind; axillæ separated, convex ; metathorax subquadrate, with a median carina, the metapleura prominent, convex. Wings hyaline, pubescent, the tegulæ and venation pale, the marginal vein a little more than twice the length of the stigmal, the latter clavate, oblique, about two thirds the length of the postmarginal. 
Anterior and posterior legs longer and stouter than the middle legs, their femora a little dilated.

Hab. St. Vincent.

Described from a single specimen.

\section{Lochites, Förster.}

\section{LOCHITES AURICEPS, sp. $\mathrm{n}$.}

ㅇ. Length 1.8 to 2 millim.; ovipositor as long as the body. Brownish yellow; the head wholly golden green; metanotum and a spot at base of middle coxæ æneous; abdomen with two or three brownish bands, usually interrupted; ovipositor black; flagellum brown-black, with two ring-joints, the funicle-joints a little wider than long. Head sparsely punctate; the thorax feebly punctate, with distinct parapsidal furrows. Wings hyaline, tegulæ pale; venation brownish, the stigmal vein short, curved at tip.

o. Length 1.5 millim. Golden green; scape, prothorax beneath, legs, including coxæ, and abdomen, except a large spot on dorsum towards apex, yellowish white.

Hab. St. Vincent.

Described from 12 specimens.

\section{Torymus, Dalman.}

Torymus rugosipunctatus, sp. $\mathrm{n}$.

o 9 . Length 1 to 2 millim. Subrobust; gold-green to bronzegreen, more rarely blue-green, with coarse umbilicate punctures ; antennæ dark brown, the scape paler beneath; legs with trochanters, tips of femora, the tibiæ, and tarsi brownish yellow, the hind tibiæ usually dusky at the middle ; coxæ and femora, except tips, bronzed or metallic. Mesonotum not longer than wide, the furrows distinct; collar short. Wings hyaline, the tegulæ and venation pallid or whitish, the marginal vein as long as the submarginal, the stigmal very minute, sessile, scarcely half the length of the postmarginal. Flagellum subclavate, the joints transverse. Ovipositor a little longer than the body, black, with a yellow tip.

Hab. St. Vincent.

Described from 8 male and 12 female specimens.

Torymus Pallidipes, sp. n.

ㅇ. Length 2 millim. Slender; head and thorax metallic green, shagreened; abdomen blue-green, smooth; scape and 
legs, except hind coxæ, pale yellowish; flagellum dark brown, the first joint the longest, the following a little longer than thick. Collar triangular; mesonotum longer than wide, with distinct furrows; scutellum about twice as long as wide, the axillæ large, projecting slightly forward into the parapsidal field ; metathorax smooth, the spiracles rather large, oval. Wings hyaline, the tegulæ and venation yellowish, the marginal vein nearly as long as the submarginal, the stigmal vein very minute.

Hab. St. Vincent.

Described from two specimens.

\section{Sxntomaspis, Förster.}

Syntomaspis PUNCTIFRONs, $\mathrm{sp}$. $\mathrm{n}$.

o. Length 2 millim. Bronze-green, shagreened, and sparsely covered with a whitish pile; face with rather coarse punctures and a median carina below the insertion of antennæ; scape, knees, tibiæ, and tarsi reddish yellow; flagellum brown-black, the joints about one and a half times as long as thick. Collar triangular; mesonotum a little longer than wide, with distinct furrows ; scutellum with a cross furrow at two-thirds its length. Wings hyaline, the venation whitish, the marginal vein almost as long as the submarginal, stigmal very minute.

Hab. St. Vincent.

Described from one male specimen.

\section{Subfamily Tridymine. \\ Tridymus, Ratzeburg.}

Tridymus solitarius, sp. $\mathrm{n}$.

đ. Length 1*4 millim. Bronze-green, feebly minutely punctate or almost smooth; face bluish; cheeks beneath the eye metallic green; abdomen towards apex blue-black; basally yellow, the yellow beneath more apparent and occupying half the length of the venter; antennæ and legs honey-yellow, the former obfuscated towards tips; coxæ greenish or bluish green basally ; flagellum moniliform, pilose, the joints a little transverse. Mesothorax trilobed, the lobes convex, the lateral much shorter than the middle lobe; collar distinct, triangular; axillæ bluish; scutellum bronze-green, strongly contrasting with the colour of the axillæ, and with a transverse line before its apex. Wings hyaline, pubescent, the venation brown, the marginal 
vein once and a half as long as the stigmal, the latter ending in a rather large circular stigma.

Hab. St. Vincent.

Described from a single specimen.

\section{Subfamily Preromaline. \\ Tribe Chiropachides. \\ Acroconmus, Förster.}

Acrocormus megastigmus, sp. $\mathrm{n}$.

ot. Length $2 \cdot 1$ millim. Dull metallic green, confluently punctate; pleura, hind femora, and abdomen æneous black, smooth, shining; scape and legs, except coxæ, brownish yellow, anterior and middle femora and posterior tibiæ dusky. Flagellum cylindrical, pilose ; the first funicle-joint the longest, almost as long as the scape, the following joints gradually subequal. Pronotum longer than its width at base, narrowed into a neck anteriorly. Mesonotal furrows delicate but complete, the lateral lobes short, the middle lobe twice as long as wide. The axillæ extend forward into the field of the parapsides to a line with the tegulæ. Scutellum with a straight impressed line at the sides. Metathorax with a median carina. Wings hyaline, ciliate, with a dusky substigmal band, extending to the middle of the wing, and a small dusky spot at the middle below the base of the marginal vein ; marginal vein slender and long, about as long as the submarginal vein; stigmal vein short and terminating in a large oblong stigma that runs parallel with the postmarginal. Anterior femora not thicker than the hind femora; posterior tibiæ with two apical spurs.

Hab. St. Vincent.

Described from one specimen. The large stigma, resembling that found in the genus Dinotus, at once distinguishes the species.

\section{Tribe Sphegigastrides.}

\section{Crmtogaster, Walker.}

Cyrtogaster vulgaris, Walk. Ent. Mag. i. p. 382.

Hab. St. Vincent, Europe, United States.

Four specimens of what is evidently this European species are in the collection. It is very variable in colour, from æneous black to metallic bronze and green, the legs from orange-yellow to fuscous and black, the female always having the paler-coloured 
legs. The habits of the genus in Europe seem not to be known, in Florida $I$ have reared a species from an Aphis, and its habits are therefore identical with Pachyneuron.

\section{Tribe Diparides.}

\section{Lelaps, Haliday.}

Of this interesting genus two distinct species occur in St. Vincent, distinguished as follows:-

Greenish æneous or æneous black; pleura, metathorax, and abdomen hlack.

‥ Pedicel, middle of funicle, club, and legs luteous; wings with a longitudinal fuscous band extending to the stigmal vein, and between this and the apex of the wing is a large fuscous spot.

đ. Flagellum long, black, pilose; wings wholly hyaline....................... Lulchricornis, Hal. Brownish yellow.

ㅇ. Antennæ, except 2 to 4 apical joints of funicle and the basal joint of club which are black, honey-yellow ; wings yellowish hyaline, with a spot beneath the base of marginal vein, another smaller spot enclosing the stigmal vein, and the apex of wing fuscous; between the stigmal vein and the apical fuscous part are two large oblique whitish spots that meet and form a band.

ऽ. Flagellum and abdomen black, the former pilose ; wings clear hyaline ........... L. flavescens, sp. n.

Lelaps pUlchricornis, Hal. Ann. \& Mag. N. H. xii. p. 47, ․ Hab. St. Vincent.

Of this species there are sixteen male and eleven female specimens in the collection. The male was unknown to Haliday and Walker, and agrees with the female, except as follows:-The antennæ are long, filiform, the flagellum being wholly black, the joints all long, cylindrical, pilose; wings clear hyaline; while the abdomen is longly petiolated, the body pear-shaped.

\section{LelaPs FLAVESCENS, sp. n.}

․ Length 2 to $2 \cdot 2$ millim. Brownish yellow or yellow, with coarse sparse black bristly hairs; antennæ, except the three or four apical joints of funicle and the basal joint of club which are 
black, and the legs pale yellowish or luteous, the coxæ, tibiæ, and tarsi usually white. Wings yellowish hyaline, with a spot beneath the origin of marginal vein, another smaller spot enclosing the stigmal vein, and the apex of wing dusky or black; between the stigmal vein and the smoky apical portion are two large oblong oblique whitish spots that meet and form a transverse band. Abdomen subpetiolate, conic-ovate, produced into a stylus at apex.

The male is only 1.5 millim. long, with a black pilose flagellum, the joints of which are long and cylindrical; abdomen pearshaped, black, with a long slender petiole; while the wings are clear hyaline.

Hab. St. Vincent.

Described from two male and three female specimens.

\section{Tribe Pteromalides.}

\section{Hemitrichus, Thomson.}

Hemitrichus varipes, sp. $n$.

o. Length $1 \cdot 1$ millim. Black to blue-black, rarely with an æneous tinge, the face below antennæ most frequently metallic green, the surface smooth, impunctured. Scutellum nearly twice as long as wide, convex, with an impressed cross-line just before its apex. Head transverse, wider than the thorax, the vertex broad with the ocelli subtriangularly arranged, the frons with an antennal impression. Antennæ inserted just above the mouth, the joints oblong-oval, constricted at apices, with sparse whorls of long hairs. Thorax short, the pronotum not visible from above, the parapsidal furrows distinct anteriorly, subobsolete posteriorly; axillæ small, convex ; metathorax very short, smooth, usually with a brassy tinge. Wings hyaline, the tegulæ black, the venation brown, the marginal vein long, nearly as long as the submarginal, or three times as long as the stigmal, the latter ending in an oblong stigma with a small uncus, the postmarginal a little longer than the stigmal. Legs brownish or honeyyellow, the coxæ always black, the femora variable, rarely entirely pale, more frequently dusky or black, the hind tibiæ sometimes dusky at the middle. Abdomen oval or oblong, black, rarely with an æneous tinge at base ; the second segment the longest, foveated at base.

Hab. St. Vincent.

Described from six male specimens. 


\section{Picrosctidus, Thomson.}

Picroscytus nigrocyaneus, sp. $n$.

우. Length $1 \cdot 1$ millim. Blue-black, shagreened; scape pale; flagellum clavate, brown-black, pubescent; trochanters, knees, tips of tibiæ and tarsi yellowish white. Head transverse, the occiput concave, the vertex rather sharp with the frons impressed. Antennæ inserted just above the clypeus; the flagellum filiform, with the joints a little longer than thick, the first shorter than the second; club 3-jointed, fusiform, much stouter than the funicle. Thorax subovoid, the collar distinct but short, transverse, the parapsidal furrows indicated only anteriorly; the scutellum longer than wide, with a straight impressed line at the sides; metathorax very short. Wings and venation hyaline, or the latter pallid yellowish; tegulæ yellow; the marginal vein long, only a little shorter than the submarginal, the postmarginal no longer than the stigmal. Abdomen acute-ovate, produced into a point at apex, the venter carinate or boat-shaped.

$H a b$. St. Vincent.

Described from a single specimen.

\section{Roptrocerus, Ratzeburg.}

\section{ROPTROCERUS AURATUS, sp. n.}

‥ Length 2 millim. Golden green, confluently punctate, the pleura blue-green; scape, pedicel and legs, including coxæ, orange-yellow. Head transverse, a little wider than the thorax, the vertex convex, the face with a slight antennal furrow. Antennæ inserted on the middle of the face, the scape cylindrical, extending to the ocelli; flagellum broken off at the pedicel. Pronotum distinct from above, a little dilated at the angles; parapsidal furrows entire, strongly converging toward the scutellum, the middle lobe anteriorly fully as wide as long, posteriorly scarcely one third as wide as anteriorly; axillæ distinctly separated, triangular, separated from the parapsides by a transverse grooved line on a line with the groove at base of scutellum, therefore not produced into the field of the parapsides; sides of scutellum oblique. Wings hyaline; the tegulæ and venation yellow, the marginal vein scarcely longer than the stigmal, the latter long, oblique, ending in a small stigma, the postmarginal vein slender, but as long as the marginal. Abdomen subsessile, conic-ovate, one third longer than head and thorax united, metallic green, with prominent black ovipositor; segments 2, 4, 
and 5 about equal, segment 3 the longest. Hind coxæ long, conical.

Hab. St. Vincent.

Described from a single specimen.

\section{Spintherus, Thomson.}

(?) Spintherus dubius, sp. n.

ㅇ. Length $2 \cdot 6$ millim. Blue-green, confluently punctate, the metanotum metallic green; scape and legs pale yellowish; coxæ blue-black, the femora toward base with a bluish or dusky blotch. Flagellum subfiliform; the funicle-joints, except the last, about twice as long as thick, the first longer than the pedicel, the last quadrate ; club 3-jointed. Head transverse, the cheeks convex. Thorax three times as long as wide, the collar distinct, narrowed anteriorly, the axillæ conjoined to the parapsides; scutellum not longer than wide, convex posteriorly; metathorax with delicate median and lateral keels or folds, the spiracles close to the metathoracic band, oval. Wings hyaline, the tegulæ and venation pale yellowish, the marginal vein long, two thirds the length of the submarginal, the stigmal vein oblique and less than half the length of the marginal, with a small stigma, the postmarginal vein nearly twice as long as the stigmal. Abdomen conic-ovate, a little longer than the head and thorax combined; the segments, except the first body-segment, about of an equal length.

Hab. St. Vincent.

Described from three female specimens.

This species is doubtfully placed in the genus Spintherus, as the teeth of the mandibles could not be counted, the mandibles being closed and partly hiaden by the clypeus.

Meraporus, Walker.

\section{Meraporus nigrocyaneus, sp. $\mathrm{n}$.}

o. Length $1 \cdot 1$ millim. Blue-black, shagreened, the mesonotum with a slight æneous tinge; scape, trochanters, tibiæ except a cloud at the middle, and tarsi yellowish white; flagellum brown-black, subclavate, pilose, the pedicel one third longer than the first funicle-joint and stouter; funicle-joints after the first a little longer than thick, very gradually widened towards club; club stouter, 3-jointed. Head transverse, wider than thorax, the face with a slight antennal impression. Thorax twice as long 
as wide, the collar very short, the parapsidal furrows indicated anteriorly, convergent; axillæ small, indistinctly separated from the parapsides. Wings hyaline, tegulæ and venation pale brownish, the marginal vein one and a half times as long as the stigmal. Abdomen ovate, depressed, with a large whitish blotch at basal half.

Hab. St. Vincent.

Described from a single specimen.

\section{Chrysoglyphe, gen. nov.}

Allied to Glyphe, Walker, but with the following differences :Head very wide, with the eyes nearly twice as wide as the thorax, the vertex very broad, the ocelli subtriangularly arranged and rather close together, the laterals being only one and a half times their diameter from the front ocellus, but full three or four times their diameter from the border of the eye. Eyes very large, occupying nearly the whole side of the head, and leaving only a short space between them and the mandibles. Both mandibles 4-dentate. Antennæ 13-jointed, filiform, pilose, the pedicel a little shorter than the first funicle-joint; ring-joints 2, minute; funicle 6-jointed, the joints a little less than twice as long as thick; club 3-jointed. Thorax ovate; pronotum visible from above only as a slight transverse line, but in reality it is triangular, the triangular portion being usually hidden in the occiput of the large broad head; mesonotum about twice as wide as long, with only slight indications of parapsidal furrows anteriorly; axillæ large and projecting obliquely forward into the field of the parapsides a little beyond the base of scutellum; metathorax short, but with a prominent punctate neck, as in Pteromalus, to which the abdomen is attached, the petiole being exceedingly short; spiracles oval, close to the metathoracic band, and with a sulcus. Wings pubescent, the marginal vein long, fully two thirds as long as the submarginal, or twice or more than twice as long as the stigmal, the latter clavate, very slightly curved; postmarginal almost twice as long as the stigmal. Abdomen conic-ovate, the venter towards base usually acutely triangularly carinated, the first body-segment the longest, as long as 2,3, and 4 combined, these about equal, 5 th a little longer than 4 th, 6th almost as long as the basal segment, 7th conic, a little shorter than the 6 th ; sheaths of ovipositor slightly prominent. 
The male has the antennæ subclavate, pilose, the first funiclejoint being only half as long as the second ; or it is long, filiform, with all the funicle-joints long, cylindrical, and pilose ; the marginal and postmarginal veins are slightly shorter than in the female, while the abdomen is clavate, with a pale spot towards the base.

Two species in this genus can be tabulated as follows :-

\section{Females.}

Golden green, scaly-punctate; legs white or pale yellowish.

Club of antennæ yellowish white; abdomen acutely

produced at apex, the basal one-third whitish. C. apicalis, sp. n.

Club of antennæ not yellowish white; abdomen

cupreous, with no white spot at base ....... C. albipes, sp. n.

\section{Males.}

Flagellum black, long, filiform, pilose, the funiclejoints from three to four times as long as thick; abdomen with a pale spot at base.......... C. apicalis.

Flagellum brown-black, shorter, subclavate, pilose, the funicle-joints only once and a half as long as thick ; abdomen cupreous at base, rarely with a minute pale spot ............... C. albipes.

\section{Chrysoglyphe apicalis, sp. n.}

․ Length 2 to $2 \cdot 2$ millim. Golden green, scaly-punctate; scape, pedicel, and club of antennæ and legs yellowish white; funicle brown-black; venter and basal one-third of abdomen white or pale yellowish; mandibles brownish yellow, 4-dentate. Head very broad, nearly twice the width of thorax, the occiput concave, the frons with a slight antennal furrow. Antennæ 13-jointed, the funicle-joints subequal, the first the longest, one third longer than the pedicel, the last scarcely longer than wide. Wings hyaline, pubescent, tegulæ yellowish, venation pale; the marginal vein long, almost as long as the submarginal, the postmargina] a little shorter, the stigmal oblique, half the length of the postmarginal. Legs white, the posterior coxæ sometimes with a dark spot at base outwardly. Abdomen conic-ovate, produced into a point at apex, the ovipositor-sheaths slightly projecting; venter at middle triangularly produced; venter and basal one-third of dorsum pale or yellowish, rest of abdomen metallic brown or greenish. 
o. Length $1 \cdot 1$ millim. Head purplish ; thorax metallic goldgreen; scape, pedicel, legs, and base of abdomen pale yellowish or white ; flagellum very long, filiform, pilose, black ; the funiclejoints all long, from three to four times as long as thick; abdomen clavate, otherwise as in the female.

Hab. St. Vincent.

Described from one male and two female specimens.

\section{Chrysoglyphe albipes, sp. $\mathrm{n}$.}

ㅇ. Length 1.8 millim. Golden green, scaly-punctate; scape, pedicel, tegulæ, and legs white, the coxæ with a greenish spot at base; flagellum brown, pubescent, the funicle-joints a little longer than thick; abdomen conic-ovate, metallic or cupreous, except along the venter, the latter triangularly carinated at the middle, white. Wings hyaline, pubescent, the venation pale; the marginal vein two thirds the length of the submarginal, the stigmal a little longer than half the length of the postmarginal.

o. Length $1 \cdot 1$ millim. Differs from the female only as follows:- Flagellum subclavate, pilose, the pedicel larger than the first funicle-joint, the latter smaller than the following joints; legs white, with the hind coxæ metallic and the anterior and middle coxæ with a spot at base; while the abdomen is clavate, metallic, rarely showing a slight pale spot at base.

Hab. St. Vincent.

Described from one female and two male specimens.

\section{GLIPHe, Walker.}

Glyphe punctata, sp. n.

-o. Length 2 millim. Blue-black, moderately confluently punctate, the head and disk of thorax with a faint æneous or metallic tinge; scape, trochanters, tips of femora, and the tibiæ and the tarsi honey or brownish yellow; flagellum brown, subclavate, the funicle-joints longer than thick, club a little thicker than the funicle, 3-jointed. Head very little wider than the thorax. Left mandible 4-dentate. Thorax subovoid, the collar exceedingly short, visible from above as a transverse line; mesonotum wider than long, with the parapsidal furrows indicated only anteriorly; metathorax very short. Wings hyaline, the tegulæ and venation pale brownish, the marginal vein long, nearly as long as the submarginal, postmarginal less than half the length of marginal, or one half longer than the stigmal, the latter clavate. Abdomen elongate, compressed, longer than the 
head and thorax together, the base beneath produced forward into a compressed triangular process that extends to the middle coxæ; hypopygial valves prominent, ploughshare-shaped.

Hab. St. Vincent.

Described from two female specimens.

Catolaccus, Thomson.

Table of Species.

Bright golden green, without scattered white hairs.

Legs orange-yellow to yellowish white, the femora with a small dusky cloud toward base ; abdomen pointed ovate, longer than head and thorax combined, metallic green. ㅇ.

0 with the venter and a spot on dorsum near the base whitish $\ldots \ldots \ldots \ldots \ldots \ldots \ldots \ldots \ldots$ C.pallipes, sp. n.

Bronze-green to æneous black or bluish green, rarely bright green.

Species with scattered white hairs.

Legs honey-yellow or pallid; the coxæ and femora, except tips, metallic.

o abdomen pointed ovate, much longer than the head and thorax together.

$\sigma^{*}$ abdomen ovate, not longer than the thorax, with a large white spot at base. C. vulgaris, sp. n.

Species bare, without the scattered white hairs.

Legs, except coxæ, pallid or whitish ; abdomen pointed ovate, longer than head and thorax united. \& $\ldots \ldots \ldots \ldots \ldots \ldots$ (?) C. helice, Walk.

\section{Catolaccus pallipes, sp. $n$.}

․ Length $2 \cdot 5$ millim. Bright golden green, confluently punctate, without the scattered white hairs; scape and legs orange-yellow or yellowish white, the coxæ, except at tips, usually metallic, the femora dusky toward base; flagellum brown. Funicle 6-jointed, the first joint twice as long as thick, the following very gradually subequal and slightly widened, the last being a little wider than long; club fusiform, 3-jointed, a little wider than the last funicle-joint. Collar short, transverse, as wide as the mesonotum. Mesonotum wider than long, with the parapsidal furrows distinct anteriorly for two thirds its length, converging behind. Scutellum transversely divided by an impressed line before its tip. Wings hyaline, the tegulæ and venation pallid or yellowish; marginal vein about half the length 
of the submarginal, or less than twice the length of the stigmal, the latter clavate; postmarginal very slightly shorter than the marginal. Abdomen pointed ovate, longer than the head and thorax combined, subsessile, metallic green; the first body-segment the longest, as long as segments 2,3 , and 4 combined, with a large fovea at base surrounding the very short petiole; segments 5 and 6 subequal, longer than the 4 th.

o. Length 2 millim. Differs from female only in its ovate abdomen, with the venter and spot on dorsum white.

Hab. St. Vincent.

Described from one male and one female.

\section{Catolaccus vulgaris, sp. $n$.}

0 . 9 . Length 1 to $3 \cdot 1$ millim. In colour variable from a bronze-green to blue-green or æneous; head and thorax confluently punctate, with short, sparse, white hairs; scape and legs honey-yellow or brownish yellow, often whitish, but with the coxæ and femora, except at tips, always metallic, bronze, or æneous. Funicle 6-jointed, filiform, the first joint a little the longest, the last longer than wide; club slightly stouter, 3jointed. Thorax as in the preceding species, only the parapsidal furrows are only distinct for half the length of the mesonotum anteriorly, and the scutellum is without the transverse impressed line before its apex. Wings hyaline, the tegulæ and venation yellowish ; marginal vein two thirds the length of the submarginal, or about two and a half times as long as the stigmal, the postmarginal about two thirds the length of the marginal. Abdomen pointed, ovate, subsessile, from one third to one half the length of the head and thorax united.

The male differs from the female decidedly in its antennal and abdominal characters. The antennæ are subfiliform, pubescent, the flagellum much stouter than the scape and pedicel, the funiclejoints very gradually subequal, almost twice as long as thick, the first joint being twice as long as the pedicel; abdomen ovate, not quite as long as the thorax, the basal half, except at junction with the metathorax, white, or at least with a large white blotch both above and beneath, the segments being about equal in length.

Hab. St. Vincent.

A common species variable in colour and size; described from many specimens. 


\section{Pteromalus, Shed.}

Pteromalus rugosopunctatus, $\mathrm{sp}$. $\mathrm{n}$.

o ․ Length 1.5 to 2.5 millim. Black or blue-black, the disk of mesonotum sometimes with an æneous tinge, and sometimes sparsely pubescent; head and thorax somewhat coarsely confluently punctate; face with striæ towards the mouth; scape and sometimes the pedicel and legs, except coxæ, pale yellowish; sometimes all the femora, except tips, black, more rarely with only a brownish blotch; flagellum brown, the first joint the longest, or twice as long as thick, the following to club subequal, not quite twice as long as thick. Thorax as in Catolaccus pallipes, except the mesonotum has the quadrilateral areas, the neck large and strongly punctate, the scutellum with a crossfurrow before the tip. Wings hyaline, the tegulæ and renation pale, the marginal vein two and a half times as long as the stigmal. Abdomen conic-ovate, much longer than the head and thorax united, metallic or bluish, the segments as in $C$. vulgaris.

The male has the same coarse punctuation and agrees in colorational detail with the female, but with the following structural differences:-The first and second funicle-joints are equal, a little shorter than the others; the abdomen is ovate, shorter than the thorax, briefly petiolated, with the dorsum at base usually cupreous, while the legs, as in the female, are variable.

Hab. St. Vincent.

Described from many specimens of both sexes.

\section{Subfamily EuLophinж.}

Hoplocrepis, Ashm.

Hoplocrepis albiclavus, Ashm. Proc. Ent. Soc. Wash. vol. i. p. 235.

Hab. Florida and St. Vincent.

Of this curious genus, described by the writer from a single female specimen collected in Florida, are two female and five male specimens that cannot be separated specifically from the Floridian specimen. The male, which was unknown to me when I erected the genus, differs from the female in having the funicle-joints of antennæ round, strongly pedicellated, and with whorls of very long hairs, while the front wings lack the conical tufts of bristles at the origin of the marginal vein. The antennæ in the male recall those in the Entedonid genus Lophocomus, Haliday. 


\section{Paraolinx, gen. nov.}

Allied to Olinx, Förster, but differs as follows :-The antennæ are flattened in both sexes, the funicle being 4 -jointed; in the male the joints are strongly excised and pedicellate, in the female transverse. Pronotum short, transverse; mesonotum a little wider than long, with distinct parapsidal furrows; metanotum short. Tibial spurs 1, 1,2, the middle spurs long, the hind spurs short, weak. Abdomen ovate, with a short petiole. Venation similar to Sympiesis, Förster, the marginal vein long, about as long as the submarginal, or only three times as long as the stigmal.

The flattened antennæ and the strongly excised pedicellate funicle-joints of the male separate the genus at once from all other described genera in the tetramerous Chalcididæ.

\section{Paraolinx lineatifrons, $\mathrm{sp}$. $\mathrm{n}$.}

o 9 . Length 1 to $1 \cdot 3$ millim. Brown-black, confluently punctate ; frons and face in the female and the whole head in the male, except the occiput, a transverse band on collar, and a line on the middle lobe of mesonotum parallel with the furrows yellow; frons and face impressed with transverse black lines; scape and legs pallid or whitish. Wings hyaline, with the apical margins ciliate. Abdomen æneous or submetallic, the male with a large white blotch at base.

Hab. St. Vincent.

Described from two male and four female specimens, only a single specimen of each sex being perfect, the others having lost their antennæ, or are otherwise imperfect.

\section{EuLopHus, Geoffroy.}

Eulophus auripunctatus, sp. n.

․ Length 2 millim. Pale honey-yellow; mesonotum, except laterally and its margin before the scutellum, golden green and strongly punctate; basal segment of abdomen cupreous, the following segments yellowish, with a black band at apex ; flagellum black, pubescent, the last three funicle-joints fully twice as long as thick, the first much shorter.

Hab. St. Vincent.

Described from a single specimen. 


\section{Diglyphus, Thomson.}

DiglyphUS? ALbipes, sp. n.

․ Length $3 \cdot 1$ millim. Black, with an æneous tinge; the collar, postscutellum, and abdomen, except tip, ferruginous ; antennæ, except toward tips, and legs white; mesonotum and metanotum rugose ; rest of the surface smooth. The antennæ extend to the metathorax, and are similar to those in Sympiesis; the funicle 4-jointed, the first joint long, about two thirds the length of the scape, following joints about equal or two thirds the length of the first. Thorax with several long black bristles, the collar triangular, the mesonotum with distinct but delicate parapsidal furrows, scutellum with two furrows. Wings hyaline, the marginal vein very long, longer than the submarginal, or about five times as long as the stigmal. Abdomen conic-ovate, a little longer than the head and thorax united, subpetiolated, with the first. segment the longest.

o. Length 2.2 millim. Agrees well with the female, except that the head, thorax, and basal abdominal segment are metallic green or cupreous ; axillæ and scutellum smooth, the latter sometimes with a longitudinal furrow as in Holcopelte; while the first funicle-joint is only a little longer than the second.

Hab. St. Vincent.

Described from one female and two male specimens.

\section{Diglyphus ? maculipennis, $\mathrm{sp} . \mathrm{n}$.}

o 9 . Length 1.5 to 2.3 millim. Aneous or bronzed, shagreened; scape, pedicel, and legs honey-yellow or white; flagellum brown-black; scutellum smooth, with a grooved line at the sides and another at the middle; flagellum filiform, the funicle 4-jointed, the joints elongate, subequal in length; abdomen sessile, conic-ovate, about as long as the head and thorax united, the basal segment the longest, occupying a little less than half the length of the abdomen, and foveated at the base by the produced neck of the metathorax. Wings hyaline, pilose, with a large fuscous discoidal blotch, the marginal vein fully as long as the submarginal; the stigmal vein long, subclavate, and very oblique, about two thirds the length of the post-marginal.

The male differs in having all the coxæ metallic and the abdomen short ovate, only about half the length of the thorax.

Hab. St. Vincent.

Both the above species are doubtfully referred to Thomson's 
genus Diglyphus, in which they differ in having a 4-jointed funicle and distinct parapsidal furrows. The posterior tibiæ in both species are two-spurred.

\section{Subfamily Entedonina.}

\section{Omphale, Haliday.}

\section{OMPhale Varicolor, sp. $\mathrm{n}$.}

0 . L Length 1.4 to 2.8 millim. Variable in colour from a dark blue to metallic green, or bronzed, and rather coarsely scalypunctate. The female is most frequently metallic green, with the coxæ and femora metallic, the rest of the legs and the scape yellowish; flagellum dark brown, pubescent, sometimes wholly steel-blue or dark blue, with the upper surface of thorax bronzed or metallic green, the coxæ and femora blue, and more rarely with the tibiæ brown or blue. The blue specimens usually have only the tarsi white. Antennæ 9-jointed, the club 3-jointed, the funicle 4-jointed; the pedicel is smooth, obconic ; the first funiclejoint is the longest, nearly three times as long as thick, the following joints subequal, the fourth being only a little longer than thick. Wings hyaline, very finely pubescent, the pubescence arranged in faint lines; the venation yellowish, the submarginal vein about two thirds the length of the marginal, the stigmal very minute, ending in a small round stigma, the postmarginal vein short, but still longer than the stigmal. Metathorax very short, nearly in a vertical line with the tip of the scutellum; the spiracles large, oval; the metapleura divided by a grooved line that extends to the base of the hind coxæ. Abdomen sessile, acutely produced at tip, and longer than the head and thorax united; the sheaths of ovipositor prominent.

The male is smaller and very variable in size and colour, although most frequently blue or bluish green with white tarsi, more rarely metallic green. The antennæ are 9 -jointed, the club 2-jointed, the funicle 5-jointed, the joints of the latter being pedicellated and furnished with whorls of long white hairs; the marginal vein is not longer than the submarginal, and the postmarginal is sometimes wanting; while the abdomen is ovate, shorter than the thorax.

$H a b$. St. Vincent.

Described from 8 male and 27 female specimens. 


\section{Holcopelte, Förster.}

This genus is well represented in St. Vincent, and the several species recognized may be separated by the aid of the following: table.

\section{Table of Species.}

Neck of metathorax not especially produced; petiole not especially long, usually short....

Neck of metathorax strongly produced; the petiole very long.

Colour variable, from cupreous to blue; scape and legs, including coxæ, white; funicle in both sexes 4 -jointed, the joints in the male pedicellate, with long hairs .........

2. Coxæ white $\ldots \ldots \ldots \ldots \ldots \ldots \ldots \ldots \ldots$

H. petiolatus, sp. $\mathrm{n}$.

4.

Coxæ metallic or blue ; funicle in female 3-jointed, in male 4 -jointed.

Scape white.......................

Scape metallic or dark.

Trochanters, except sometimes the anterior pair, tips of femora, and the tibiæ and tarsi yellowish or white.

Cupreous or metallic; face and frons coarsely punctate; second abdominal segment not longer than the following segments united, the petiole a little longer than wide, punctate.

Female with the funicle-joints oblong; male with the joirts oblong-moniliform, pubescent ............. H. metallicus, sp. $\mathbf{n}$.

Blue-black; face and frons faintly scaly; second abdominal segment longer than the following segments united, the petiole not longer than wide.

Female with the funicle-joints 2 and 3 transverse-moniliform; male with the flagellum filiform-moniliform ..

3. Legs, except coxæ, white.

H. nigrocyaneus, sp. $\mathrm{n}$.

Cupreous; second abdominal segment shorter

than the following segments united.

Female with funicle-joints longer than wide; male with the funicle-joints longer than wide, subpedunculated, and furnished with long white hairs ............. H. cupreus, sp. $\mathbf{n}$. 
Eneous black; second abdominal segment much longer than the following segments united. Female with the funicle-joints 2 and 3 moniliform .................... H. nigroæneus, sp. $\mathrm{n}$.

4. Metallic, bronze or subcupreous.

Legs and scape white; flagellum in female pale brown or yellowish, in male brownblack.

Abdomen conically produced, longer than the head and thorax united, the second segment the longest, but its length only about one third as long as the following segments united.

Female with the funicle-joints long; male with the funicle-joints longer than wide, hairy...$\ldots \ldots \ldots \ldots \ldots \ldots$.

H. productus, sp. $\mathrm{n}$.

Holcopelte petiolatus, sp. n.

o 9 . Length 1.5 to 2 millim. Blue-black to cupreous, rarely without a metallic tinge on head and thorax above, the thorax scaly-punctate; in female the scape and legs, including coxæ, white; in male the coxæ usually black : flagellum black. Head wider than the thorax; eyes large, hairy; funicle 4-jointed in both sexes, in the female the joints are long, subpedunculate, hairy, in male distinctly pedunculate, with longer hairs. Pronotum conical, much narrower than the mesonotum; scutellum with a median groove; metathorax produced into a neck at apex. Wings hyaline, fringed, the marginal vein very long, more than twice the length of the submarginal, postmarginal scarcely developed, stigmal very short. Abdomen with a long petiole; in the female with the body produced at tip as in the Pteromalid genus Isocratus, in male truncate at apex. In both sexes the first body-segment is very long and foveated at base above for the reception of the long petiole.

Hab. St. Vincent.

Described from seven male and four female specimens.

In the shape of the abdomen with its long petiole, the strongly produced neck of the metathorax, and in both sexes having four joints to the funicle, this species is quite distinct from those that follow. In fact, I think these characters entitle it to subgeneric rank.

Holcopelte metallicus, sp. $n$.

o $q$. Length 1.5 to 2 millim. Metallic greenish; antennæ, 
eoxæ, and femora, except tips, metallic, the rest of the legs honeyyellow or whitish; anterior legs in male usually wholly honeyyellow. Frons and face strongly punctate; thorax scaly.

In the female the flagellum is subclavate, with a 3 -jointed funicle, the first joint the longest, the following subequal, all oblong; abdomen pointed ovate, as long as, or a little longer than, the thorax, the second segment the longest, about as long as the following segments united; segments 7 and 8 are a little longer than any of the others except the second; the petiole is only a little longer than wide.

In the male the flagellum is filiform-moniliform, the joints subpedicellate, very little longer than thick; abdomen oval, scarcely half the length of the thorax, the apex usually truncate, from the apical segments being retracted within the large second segment; the petiole is longer than in the female.

Hab. St. Vincent.

Described from 6 male and 14 female specimens.

\section{Holcopelte nigrocyaneus, sp. n.}

o 오. Length 1 to 2 millim. Blue-black, rarely with a slight æneous tinge, scaly-punctate; trochanters, tips of femora or knees, and the tibiæ and tarsi pale yellowish or white; sometimes in the female the anterior legs, except coxæ, are white, while in the male all the legs, except the coxæ and the posterior femora, are white, although sometimes in this sex the tibir are dusky.

In the female the flagellum is clavate or subclavate, with the 2nd and 3rd funicle-joints transverse-moniliform; abdomen ovate, not quite as long as the thorax, the petiole not or scarcely longer than wide, the second segment usually as long as, or a little longer than, the following segments united.

In the male the flagellum is filiform, hairy, the funicle-joints oblong-moniliform, subpedicellate.

\section{Hab. St. Vincent.}

Described from many specimens.

Holcopelte cupreus, sp. $\mathrm{n}$.

$\delta$ ․ Length $1 \cdot 5$ to 2 millim. Cupreous; scape and legs, except coxæ, white; flagellum black; punctation scaly.

In the female the flagellum is filiform, pilose, the funiclejoints long, subpedicellate; abdomen ovate, pointed at apex, the petiole short, the second segment the longest but shorter than the following segments united. 
In the male the flagellum is metallic, covered with long fine hairs, the funicle 4-jointed, the joints pedicellate; abdomen rounded, briefly petiolated, the petiole being punctate.

$H a b$. St. Vincent.

Described from two male and nine female specimens.

Comes nearest to $H$. metallicus, but readily distinguished by the colour of the antennæ and legs and the shape of the funiclejoints.

\section{HolCOPELTE NIGROANEUS, sp. n.}

o ․ Length 1 to 2 millim. Eneous black, scaly-punctate; scape and legs, except coxæ, white; flagellum dark brown.

In the female the flagellum is filiform, the funicle 3 -jointed, the joints subpedicellate, the 2 nd and 3rd round-moniliform; abdomen ovate, the petiole a little longer than thick, shagreened, the second segment much longer than all the following segments united.

The male is blue-black, with a cupreous tinge above; the flagellum pilose, the joints oblong-moniliform, subpedicellate; abdomen small, truncate at apex, with a rather long petiole.

Hab. St. Vincent.

Described from one male and nine female specimens.

\section{Holcopelte productus, sp. n.}

o 9 . Length 1 to 1.5 millim. Metallic, bronze or subcupreous, faintly and feebly shagreened; the scape and legs, including the coxæ, white; flagellum yellowish. Abdomen conically produced, longer than the head and thorax united, the petiole wider than long, the second segment the longest but only about one third as long as the following segments united; flagellum filiform, the joints long. Wings hyaline, the marginal vein very long, three times as long as the submarginal; stigmal vein clavate, the postmarginal a little longer than the stigmal.

In the male the abdomen is oval, subsessile, pointed at apex; flagellum black-pilose; while in this sex the anterior coxæ are dark.

\section{Hab. St. Vincent.}

Described from one male and three female specimens.

The conically produced abdomen of the female and the venation readily separate this species from those previously described. 


\section{Derostenus, Westwood.}

Table of Species.

Females.

Abdomen almost round...............

Abdomen conically produced or conic-ovate.

Bronze-green; legs pale yellowish.

Front wings with 4 brown spots ...... D. quadrimaculatus, sp. n.

Thorax gold-green, scaly-punctate, rarely bronzed ; head, thorax, and abdomen beneath blue-black, the abdomen above more or less metallic; legs, except anterior coxæ, and scape white.

Front wings hyaline $\ldots \ldots \ldots \ldots \ldots$ D. acutus, sp. n.

2. Eneous; scape and legs white ....... D. rotundus, sp. n.

\section{Males.}

Abdomen ovate; head and abdomen purplish, the thorax greenish æneous; scape and legs, except anterior coxæ, white..... D. acutus, sp. n.

Abdomen round; bluish or purplish, the thcrax with an æneous tinge above; abdomen with a transverse white spot at base; scape and legs, except coxæ and a dusky streak on femora, white ....... D. rotundus, sp. n.

Derostenus quadrimactlatus, $\mathrm{sp} . \mathrm{n}$.

q. Length $1 \cdot 1$ millim. Bronze-green, the thorax feebly shagreened; antennæ except club, and legs except coxæ pale brownish yellow; club brown-black; hind coxæ blue. The antennæ are 9-jointed; the first funicle-joint is smaller than the 2 nd and $3 r d$, which are about equal; the 4 th is quadrate, larger and thicker than the preceding and distinctly separated from the club and the 3rd funicle-joint; the club is 3-jointed, conic-ovate, and nearly three times as long as the last funiclejoint. Wings hyaline, with four brown maculæ: one at the middle of the marginal vein, another enclosing the stigmal vein; while the other two are on the hind margin, each heing directly opposite those first mentioned. Abdomen conic-ovate, longer than the head and thorax united, and produced into a prominent though short oviduct at the tip.

Hab. St. Vincent.

Described from a single specimen. 
The spotted anterior wings and the shape of the abdomen readily distinguish the species.

Derostenus acutus, sp. n.

o ㅇ. Length 1 millim. Thorax gold-green, scaly-punctate; head wider than thorax, smooth, blue-black or purplish with an æneous tinge; flagellum dark brown, covered with a whitish pubescence; scape and legs white; thorax and abdomen beneath purplish or bluish, the latter above with an æneous tinge. Wings hyaline. The abdomen is acutely produced, briefly petiolated, and as long as the head and thorax united.

The male agrees well with the typical female except in the antennæ, shape of abdomen, and the colour of the anterior coxæ; the flagellar joints are slightly longer, with long hairs, the anterior coxæ bluish or metallic, the middle and posterior coxæ usually dusky at base, while the abdomen is subovate or spatulate.

\section{Hab. St. Vincent.}

Described from two male and twelve female specimens.

Derostenus rotundus, sp. n.

o 9 . Length 0.65 to 0.8 millim. Blue-black or purplish, impunctate, the upper part of thorax and abdomen æneous; flagellum brown-black; scape and legs white; wings hyaline; abdomen rounded, briefly petiolated, not longer than the thorax, usually shorter : flagellar joints in female about twice as long as thick, pubescent; in male shorter, with longer hairs.

$H a b$. St. Vincent.

Described from six male and four female specimens.

The rounded abdomen distinguishes this species from all others in the genus.

Chrysocharis, Förster.

Table of Species.

Females.

Thorax brownish yellow, with a violaceous tinge

anteriorly $\ldots \ldots \ldots \ldots \ldots \ldots \ldots \ldots \ldots \ldots \ldots$

Thorax always metallic or blue-black.

Abdomen conic-ovate.

Blue-black.

Thorax and abdomen metallic green, the former scaly-punctate ; legs entirely white.

Anterior wings with a substigmal blotch .. C. stigmatus, sp. n. 
Thorax above sometimes metallic, smooth; legs

bluish, tarsi alone white.

Anterior wings hyaline..$\ldots \ldots \ldots \ldots \ldots$ C. lividus, sp. n.

Abdomen rounded.

Thorax and abdomen metallic green, the former

scaly-punctate; scape and legs white ....... lividiceps, sp. n.

2. Abdomen conic-ovate; head black, abdomen brownish black.

Legs honey-yellow .................

C. thoracicus, sp. n.

\section{Males.}

Blue-black.

Head posteriorly metallic ; legs blue, with the tarsi alone white; wings hyaline $\ldots . \ldots \ldots \ldots$. C. lividus.

Occiput and thorax above metallic or bronzegreen; legs white; wings with a substigmal blotch ........................

Head much wider than thorax, blue; thorax above golden green, scaly-punctate; legs, except coxæ and scape, white ................ C. lividiceps.

\section{Chrisocharis stigmatus, sp. $\mathrm{n}$.}

o ㅇ. Length $1 \cdot 1$ to $1 \cdot 2$ millim. Blue-black; in female with the upper part of thorax metallic green; in male with only the scutellum and metathorax tinged with æneous, smooth. Scape and legs, except coxæ in the male, whitish or honey-yellow. Head rather large, the frons impressed, the vertex acute. Prothorax distinct, narrowed anteriorly. Wings hyaline, ciliated, with a brownish blotch beneath the stigmal vein. Abdomen in female ovate, in male oblong, the short petiole in the latter brown.

Hab. St. Vincent.

Described from one male and one female specimen.

The shape of the head and the collar strikingly resemble those in the genus Derostenus; but the number of joints in the antennæ being one less, cause me to place this species in Chrysocharis. It is readily distinguished by the substigmal blotch in the anterior wing.

\section{Chrysocharis lividus, sp. n.}

o ․ Length 0.85 to 1 millim. Blue-black, impunctured, the tarsi and tibial spurs alone white. Wings hyaline. Abdomen in female subsessile, ovate, about as long as the thorax; in 
male oblong, with a whitish spot at base; the antennæ with whitish hairs, the first funicle-joint the longest.

Hab. St. Vincent.

Described from one male and one female specimen.

Chrysocharis lividiceps, $\mathrm{sp}$. $\mathrm{n}$.

o 9 . Length 1.2 millim. Thorax and abdomen metallic or gold-green, the former scaly-punctate; head and thorax, at sides and beneath, blue-black; the small side-piece at base of hind wings violaceous; scape and legs white; flagellum brown, pubescent. Wings hyaline, pubescent. Abdomen rounded, only two thirds the length of the thorax.

The male is slightly smaller, measuring but 1 millim in length, and with the head larger, the flagellum longer, with longer black hairs, the flagellar joints somewhat contracted at tips, while the coxæ are æneous; otherwise it resembles the female.

Hab. St. Vincent.

Described from three males and one female.

Chrysocharis thoracicus, sp. $\mathrm{n}$.

9. Length 1.5 millim. Head black; thorax and legs pale brownish yellow, the former with a distinct violaceous tinge anteriorly ; antennæ pale brown, hairy, the funicle-joints elongate. Wings large, hyaline and ciliate. Abdomen conic-ovate, as long as the head and thorax together, brown-black, the very short petiole yellow.

Hab. St. Vincent.

Described from a single female.

Closterocerus, Westwood.

Table of Species.

Females.

Blue-black; tarsi white................. C. leucopus, sp. n.

Males.

Blue-black; tarsi white................... C. leucopus.

Blue-black; head above metallic green; legs white, the femora and tibiæ dusky at the middle.

Abdomen without a pale spot at base ......... C. auriceps, sp. n. Aneous black, metathorax and abdomen bluish, the latter with a white spot at base; legs white..... C. albipes, sp. n, 
Closterocerus leucopus, sp. $\mathrm{n}$.

of 오. Length 0.8 to 0.9 millim. Blue-black, impunctured, the scutellum and base of abdomen more distinctly blue; sometimes with an æneous tinge; tarsi white. Wings hyaline, ciliated. Abdomen in female pointed ovate, as long as the head and thorax united ; in male oblong, narrowed towards base, and not longer than the thorax. Antennæ short, fusiform, pilose.

Hab. St. Vincent.

Described from one female and four male specimens.

Closterocerus auriceps, sp. $\mathrm{n}$.

d. Length 0.8 millim. Blue-black, the scutellum æneous, the head above metallic green or gold-green; legs pale or white, the coxæ æneous, the femora and tibiæ dusky at the middle. Wings clear hyaline, fringed. Abdomen oval, shorter than the thorax, with no pale spot at base.

Described from a single male specimen.

Closterocerus albipes, sp. $n$.

5. Length 0.8 millim. Eneous black, the metathorax and abdomen bluish, the latter with a large white spot at base; collar anteriorly with a violet tinge; legs white, with only the coxæ dusky basally. Wings hyaline, pubescent. Antennæ 8-jointed, flattened, brown, pubescent, the third funicle-joint the longest.

Hab. St. Vincent.

Described from two male specimens.

\section{Chrisocharodes, gen. nov.}

Allied to Chrysocharis, Förster, and Derostenus, Westwood, but separate at once from both by its antennal characters. In both sexes the antennæ are 7 -jointed, not 8- or 9 -jointed; in the female they are subclavate, pubescent, with a 2 -jointed funicle and a 3-jointed club ; in the male the funicle is 3-jointed, each joint contracted at apex into a pedicel, while the base or thickened part is furnished with a whorl of long hairs ; club only 2-jointed. The head is rather large, transverse, with a frontal impression pronotum conical ; metathorax somewhat lengthened; the abdomen is oval, much shorter than the thorax, distinctiy petiolated, and with the second segment the longest, twice as long as the third. 


\section{Chrysocharodes petiolata, sp. n.}

$\delta$ ․ Length $1 \cdot 1$ millim. Blue-black, upper part of thorax and base of abdomen with a metallic tinge; disk of thorax scalypunctate; metapleura and coxæ bluish; legs brownish yellow; antennæ, including scape, black or dark brown; flagellum once and a half as long as the scape, pubescent, the second funicle-joint a little longer than the first; club 3-jointed, fusiform, distinctly separated from the funicle. Wings hyaline, ciliated, the short stigmal vein ending in a small round stigma with an uncus. Abdomen oval, two thirds the length of the thorax, the petiole once and a half as long as wide, shagreened.

The male is at once distinguished from the female by the antennæ, the funicle being 3-jointed, the joints pedicellate at tips and with whorled hairs ; club 2-jointed; thorax above golden green, scaly; while the abdomen is oblong, with the petiole fully twice as long as wide.

Hab. St. Vincent.

Described from one male and one female specimen.

\section{Subfamily Tetrastichinæ.}

\section{Ceratoneura, gen. nov.}

Antennæ 10-jointed; in female subclavate, with two ring-joints and a 3 -jointed club, covered with a fine pubescence: in male filiform, with one ring-joint and a 4-jointed funicle, the funiclejoints contracted toward apex and with long hairs. Head transverse; the ocelli subtriangularly arranged, the laterals being much closer to the front ocellus than to the margin of the eye: eyes broadly oval; frons with two grooves for the scapes of the antennæ. Thorax subovoid, the pronotum short, the mesonotum without a median furrow; the scutellum convex, without the grooved lines on disk; the metathorax very short, smooth, rounded behind, with a delicate median carina. Wings, except the posterior pair, as in Tetrastichus; hind wings with a long. clavate marginal vein. Abdomen briefly but distinctly petiolated, in female ovate, pointed at tip, in male oval.

In the distinct petiole, and in other characters pointed out, this genus is quite distinct from all others placed in this group. The female antennæ agree with Tetrastichus, Hal.; but the male antennæ are different, and the wholly different mesonotum and scutellum readily separate it. The other genera having no. 
furrows on mesonotum and scutellum are Anozus, Förster, Gyrolasia, Förster, and Syntomosphyrum, Förster; but the absence of a stigmal vein and difference in antennæ distinguish Anozus, the sessile abdomen, strongly fringed wings, and 8-jointed antennæ distinguish Gyrolasia, while Syntomosphyrum is separated by the sessile abdomen, 8-jointed antennæ with no ringjoints, and the venation of hind wings.

Ceratoneura petiolata, sp. $n$.

of $q$. Length 1.5 to 1.9 millim. Black, smooth, impunctured; face with striæ converging towards mouth; petiole of abdomen yellow ; scape, trochanters, tips of femora, tibiæ, and tarsi honeyyellow; rest of legs black; flagellum brown.

In the female the flagellum is subclavate, the funicle-joints about twice as long as wide, the club thicker, fusiform ; in male filiform, much longer, pilose, the funicle-joints three or more times longer than wide. Wings hyaline, with a short fringe at the margins. Abdomen in female ovate, about as long as the thorax.

Hab. St. Vincent.

Described from twelve female specimens.

Ceratoneura pallida, sp. n.

o. Length 2 millim. Pale brownish yellow, smooth; face with striæ converging toward mouth ; eyes and abdomen laterally and at apex brown; scape, pedicel, and legs whitish. Wings hyaline. Abdomen oval, a little shorter than the thorax, the segments very nearly equal in length. The scape beneath towards apex is slightly dilated, while the funicle-joints are more than three times as long as wide.

Hab. St. Vincent.

Described from a single male specimen.

Grrolasia, Förster.

Table of Species.

Females.

Body entirely black or metallic $\ldots . . . \ldots \ldots .$.

Head and thorax black, smooth, shining; abdomen conic, brown.

Legs honey-yellow, the coxæ and femora black or brown.................... Gicolor, sp. n. 
2. Black, the thorax above æneous or black.

Abdomen conic-ovate; legs pale or yellowish, the hind coxæ and femora alone dusky ....... G. ciliata, sp. n.

Abdomen conically produced, longer than the head and thorax united; all coxæ dusky or black; anterior and middle femora dusky at middle; hind femora slightly swollen, dark brown or black ................ Gemorata, sp. n.

Metallic or bronze-green.

Abdomen oval, a little longer than the thorax; legs pale or honey-yellow............ G. metallica, sp. n.

Gyrolasia bicolor, sp. n.

․ Length 0.85 millim. Head and thorax black, shining, impunctured; abdomen conic-ovate, a little longer than the head and thorax together, brown; flagellum and legs (except trochanters, tibiæ, and tarsi, which are honey-yellow) brown-black. Wings hyaline, strongly fringed.

Hab. St. Vincent.

Described from one female specimen.

\section{Gyrolasia ciliata, sp. n.}

오. Length 0.8 millim. Head and thorax, except above, and the abdomen black; thorax above æneous black; antennæ brown ; the flagellum rather long, filiform, with long hairs ; legs, except a dusky shade at base of hind coxæ and their femora, pale or yellowish white. The whole surface is smooth, shining; the wings hyaline, with a very long fringe; while the abdomen is conic-ovate, very little longer than the head and thorax united.

Hab. St. Vincent.

Described from two female specimens.

Grrolasia femorata, sp. n.

ㅇ. Length 0.8 to 1 millim. Black, smooth, impunctured; flagellum subclavate, brown, pubescent; legs, except coxæ and lemora, whitish or pale honey-yellow, the coxæ brown or black, the anterior and middle femora usually dusky or brown-black. Wings hyaline, strongly fringed. Abdomen conically produced, about one third longer than the head and thorax united.

Hab. St. Vincent.

Described from eight female specımens. 
Groolasia metallica, sp. n.

․ Length 0.85 millim. Metallic or bronze-green, impunctate, the under surface of thorax and abdomen blue-black; flagellum brown, pubescent; legs pale or honey-yellow, the coxæ alone showing a dusky spot at base. Wings hyaline, strongly fringed. Abdomen oval, a little longer than the thorax.

Hab. St Vincent.

Described from one female specimen.

In the metallic colour, more compact form, the collar not being narrowed before, and in the shape of the abdomen this species is widely separated from all the others.

\section{Syntomosphyrum, Förster.}

\section{STNTOMOSPHYRUM INSULARIS, sp. n.}

ㅇ. Length 0.9 millim. Black, smooth, shining; the trochanters, knees, tips of tibiæ, and tarsi honey-yellow; scape pale brown; flagellum brown-black, pubescent, scarcely as long as the head, the joints short, submoniliform. The head is transverse, excavated, or concave behind, the occipital margin being sharp; frons deeply impressed, the anterior ocellus being in the furrow, while the lateral ocelli are nearer to the front ocellus than to the margin of the eye. Thorax short, ovoid, the collar transverse, visible from above as a curved line; mesonotum a little wider than long, with deeply defined parapsides, the middle lobe being scarcely longer along the sides than the width anteriorly; scutellum smooth, without distinct grooved lines, rarely slighily indicated at extreme base. Wings hyaline, pubescent, the nervures pale brownish, margins fringed with short cilia. Abdomen oral, not quite as long as the thorax.

o. Length 1 millim. Differs from the female in having much longer filiform antennæ, the joints of the flagellum much longer than thick, pubescent, the anterior and middle legs brownish yellow, while the abdomen is oblong, much narrower than the thorax, and as long as the head and thorax united.

Hab. St. Vincent.

Described from one male and one female specimen.

\section{Tetrastichodes, Ashmead.}

This name was proposed, some years ago, for a Tetrastichid found in Florida. It differs from Tetrastichus, Haliday, in 
having no median furrow on the mesoscutum, a character peculiar to the genera Ceranisus, Walk., Baryscapus, Först., Melittobia, Westw., and Cirrospilus, Westw.; but Ceranisus and Baryscapus have the scape greatly thickened or dilated, in Melittobia the female has a conically produced collar and eight-jointed antennæ, the male being subapterous with dilated and twisted antennæ and subobsolete eyes, while Cirrospilus has but sevenjointed antennæ.

The two species placed here, from St. Vincent, may be thus distinguished :-

Smooth, impunctate, metallic green or cupreous; abdomen conically produced.

Legs, except hind coxæ, white ............. T. cupreus, sp. n.

Scaly-punctate, dull bronzy-brown or bronze-green;

abdomen cylindrical, conically pointed.

Coxæ and hind femora black, the anterior and middle femora, except tips, dark brown, rest of legs yellow $\ldots \ldots \ldots \ldots \ldots \ldots \ldots \ldots$. T. femoratus, sp. n.

\section{Tetrastichodes cupreus, sp. $n$.}

$\checkmark$ ․ Length variable, from 0.9 to 2 millim. Metallic green or cupreous, smooth, impunctate; scape and legs yellowish or pale brownish-yellow; hind coxæ metallic green; flagellum brown. Abdomen in male ovate or conic-ovate, not or very slightly longer than the thorax, with a yellow blotch at base ; in female conically produced, a little longer than the head and thorax united, and without the jellow blotch at base.

Head transverse, with a deep frontal impression; mandibles piceous or ferruginous; the anterior ocellus is situated in the frontal impression, the lateral ocelli being as near to the margin of the eye as to the frontal ocellus. Thorax ovate, the collar rounded anteriorly, the mesonotum slightly longer than wide, the middle lobe being longer than wide along the anterior margin; scutellum convex, with two furrows; metathorax smooth. Wings hyaline, pubescent, the cilia short, the venation pallid. Antennæ in female subclavate, pubescent, the funicle-joints being not more than twice as long as wide; club a little stouter, 3-jointed: in male filiform, piluse, the funicle-joints at least three times (or slightly more) as long as wide.

Hab. St. Vincent.

Described from 10 male and 24 female specimens. 


\section{Tetrastichodfs femoratus, $\mathrm{sp} . \mathrm{n}$.}

of 9 . Length 1.5 to 2 millim. Scaly-punctate, bronzy-brown or metallic green, the head somewhat purplish ; scape, pedicel, and legs honey-yellow; middle and anterior femora towards base and the terminal tarsal joint brownish; all coxæ and hind femora, except tips, black; flagellum brown. The flagellum in female clavate, the first funicle-joint longer than wide, the second and third quadrate; club fusiform, 3-jointed. Abdomen in female conic-ovate, cylindric, very slightly longer than the head and thorax united, scaly-punctate, the segments 1, 2, and 3 long, about equal, occupying most of the surface: in male oblong-oval, not longer than the thorax.

Hab. St. Vincent.

Described from one male and one female specimen.

\section{Tetrastichus, Haliday.}

This genus is numerously represented in all parts of the world and the species are exceedingly difficult to separate. Mr. F. Walker, in his 'Monographia Chalcididum,' under the genus Cirrospilus has described numerous species from England and elsewhere; but as he gave no tables of his species, and, moreover, seems to have confused several genera under this genus, I have been unable to follow him, and the species described by me may or may not be identical with some of his species.

The six species in the St. Vincent collection may be distinguished by the following table:-

Species pale $\ldots \ldots \ldots \ldots \ldots \ldots \ldots \ldots \ldots \ldots$.

Species black or blue-black, smooth or but feebly sculptured $\ldots \ldots \ldots \ldots \ldots \ldots \ldots \ldots \ldots$.

Bright metallic green to blue-green, rather strongly punctate.

Legs, except coxæ, brownish yellow or reddish yellow ..................... T. cupreus, sp. n.

2. Blue-black, subopaque, or black, shining.

No pale spot at base of abdomen.

Abdomen in female conic-ovate.

a. Subopaque.

Scape and legs, except coxæ and femora, brownish yellow ; antennæ not especially long; mesoscutum with a row of punctures at the lateral margins .... T. vulgaris, sp. n. 
b. Shining, black.

Scape, pedicel, and legs honey-yellow or pale brownish yellow; hind femora sometimes more or less dusky; antennæ long; mesoscutum without a row of punctures at the lateral margins ...... T. longicornis, sp. n.

Antennæ short; legs, except coxæ and femora, pale brownish or honey-yellow ; hind wings acute at tips $\ldots \ldots \ldots \ldots$ T. acutipennis,sp.n.

A pale spot at base of abdomen.

Black with a faint æneous tinge.

Scape, legs, and basal abdominal segment honey-yellow, the femora dusky towards base.................... T. basilaris, sp. $\mathrm{n}$.

3. Brown or brownish yellow.

Frons not closely punctured with thimble-like punctures, at the most with only a row of punctures.

Apex of antennæ, head and thorax above, and the apex of the abdominal segments dusky or brown.............. T. fasciatus, sp. n.

Frons closely punctured with thimble-like punctures $\ldots \ldots \ldots \ldots \ldots \ldots \ldots \ldots$. T. punctifrons, sp. n.

\section{Tetrastichus cupreus, sp. $\mathrm{n}$.}

$\delta$ 오. Length 1.5 to 2 millim. Bright metallic green or cupreous, more rarely bluish green, punctate ; scape, pedicel, and legs, except coxæ, yellow; coxæ metallic; flagellum brown, pubescent. Head transverse, a little wider than the thorax, punctate, the vertex rounded; ocelli red, connected by grooved lines; frons with a $\mathbf{V}$-shaped antennal impression. Flagellum in female brown, pubescent, with two ring-joints, the funicle-joints oblong; club stout, fusiform, 3-jointed : in male filiform, pilose, the first funicle-joint scarcely longer than thick, the following jnints almost equal, oblong, from $1 \frac{1}{2}$ to 2 times as long as thick. Thorax subovoid, with the collar distinct, transverse, rounded anteriorly; mesonotum not quite as long as wide, with distinct parapsidal furrows, the middle lobe with a median grooved line, usually subobsolete anteriorly, and with two punctate lines along the lateral margins; scutellum convex, with two lines on disk and a short median line at base; metathorax short, areolated; pleura and coxæ strongly punctate. Wings hyaline, pubescent, the venation yellowish. Abdomen sessile, ovate, cylindric, 
punctate; in female rarely longer than the thorax, in male shorter, the first segment the longest, the following segments short, nearly equal.

Hab. St. Vincent.

Described from 145 specimens.

Tetrastichus vulgaris, sp. $\mathrm{n}$.

ㅇ. Length 1.5 to 2 millim. Blue-black at sides and beneath; the dorsum black, subopaque, feebly shagreened ; abdomen conicovate, æneous black; scape, pedicel, trochanters, knees, tibiæ, and tarsi honey-yellow; flagellum brown. Head transverse, antero-posteriorly very thin, the vertex therefore very sharp; frons deeply impressed, punctate; trophi ferruginous. Antennæ shorter than the thorax, the pedicel $\frac{1}{3}$ the length of the scape; the flagellum subclavate, very slightly more than twice the length of the scape, brown, pubescent, the three funicle-joints a little longer than thick, the third the widest; club stouter, 3-jointed. Thorax short, ovoid, feebly shagreened, subopaque; pronotum short, visible from above as an arcuate ridge; mesonotum wider than long, the middle lobe with a median grooved line and a row of punctures along the parapsidal furrows; parapsides with an oblique line just above the tegulæ; scutellum convex, with two median grooved lines; metathorax very short, abrupt. Wings hyaline, pubescent, the venation pale yellowish. Abdomen conicovate, a little longer than the head and thorax united, depressed. or flat above, boat-shaped beneath.

Hab. St. Vincent.

Described from 58 female specimens.

Tetrastichus longicornis, $\mathrm{sp} . \mathrm{n}$.

ㅇ. Length 1.5 to 1.8 millim. Black, shining, much slenderer than $T$. vulgaris; the antennæ very long, extending to base of abdomen or beyond, the flagellum being filiform and nearly five times as long as the scape, the joints elongate, about three and a half times as long as thick. Thorax smooth, the collar conical, the mesoscutum without a row of punctures along the parapsidal furrows. Wings hyaline, pubescent, the venation pale brownish yellow. Legs pale yellowish, the femora more or less dusk medially, the anterior pair sometimes entirely pale. Abdomen as in T. vulgaris, but piceous along the venter.

Hab. St. Vincent.

Described from nine female specimens.

LINN. JOURN.-ZOOLOGY, VOL. XXV. 
The long antennæ, closely resembling those of a male, the conical pronotum and its smooth surface, readily distinguish the species.

\section{Tetrastichus acdtipennis, $\mathrm{sp} . \mathrm{n}$.}

ㅇ. Length 0.9 millim. Black, shining, impunctate; antennæ and legs, except the coxæ and the femora at the middle, honeyyellow or pale brownish yellow; mouth-parts yellowish. Head transverse, deeply impressed anteriorly on the frons, the vertex therefore thin antero-posteriorly. Thorax short, oval, the collar very short, scarcely visible from above; the mesonotum smooth, broader than long, with the parapsidal furrows distinct, the median grooved line very faint; the scutellum convex, with two grooved lines; the metathorax very short, smooth. Wings hyaline, fringed; the hind wings lanceolate, acutely pointed at tips. Abdomen conic-ovate, pointed at tip, depressed above, convex beneath, and æneous black.

Flagellum clavate, pubescent, about twice as long as the scape ; the funicle-joints submoniliform ; the club stout, fusiform.

Hab. St. Vincent.

Described from two female specimens. The species is distinguished from the others by its smaller size, colour of antennæ, and the pointed hind wings.

\section{Tetrastichus basilaris, sp. n.}

ㅇ. Length 1.5 to 2 millim. Black, shining, with a slight æneous tinge; head below the antennæ and the eyes piceous or pale ferruginous ; scape, pedicel, a spot at base of abdomen, and the legs yellowish or whitish, the coxæ black, the femora sometimes dusky toward base. The face has two rows of punctures between the facial impression and the eyes ; the thorax is faintly alutaceous; the collar distinct, rounded before and with a row of punctures along the posterior margin; mesoscutum with a single row of punctures along the parapsidal furrows. Wings hyaline, pubescent, the venation pallid or pale brownish yellow. Abdomen conic-ovate or conically produced, longer than the head and thorax together.

Flagellum clavate, two and a half times as long as the scape; the funicle-joints nearly twice as long as thick, the club stouter, three-jointed.

Hab. St. Vincent.

Described from 50 female specimens. 
Tetrastichus fasciatus, sp. $\mathrm{n}$.

of 우. Length 1.5 to 2 millim. Brownish yellow, smooth, impunctured; stemmaticum, flagellum, excluding the pedicel, eyes, grooved lines on thorax, sometimes the sides of metathorax, and the apical margins of the abdominal segments dark brown; the middle of abdomen sometimes wholly brown; scape, pedicel, and legs pale yellowish. The space between the eye and the facial impression smooth, or at the most with only a few punctures; pronotum short, rounded before; mesoscutum longer than wide, with some punctures along the parapsidal furrows; metathorax very short, abrupt, with a delicate median carina. Wings hyaline, pubescent. Abdomen conically produced, a little longer than the head and thorax united, with a style-like tip, the ovipositor being slightly exserted.

The female flagellum is clavate; the funicle-joints 1 and 2 nearly twice as long as thick, the third slightly shorter and stouter; while the club is ovate, 3-jointed, and stouter than the last funicle-joint. In the male the stemmaticum, occiput, a broad median band on thorax, metathorax, and abdomen are brownish black ; the flagellum is long, filiform, pilose, with the funiclejoints, after the first, about three,times as long as thick, the first joint being moniliform; while the abdomen is oblong-oval, not quite as long as the thorax.

Hab. St. Vincent.

Described from one male and 14 female specimens.

\section{Tetrastichus pUnCtifrons, $\mathrm{sp} . \mathrm{n}$.}

ㅇ. Length $2 \cdot 2$ millim. Very close to $T$. fasciatus, but the head, except the face below the antennæ and the eyes, is distinctly metallic or æneous, the frons being closely punctate with thimblelike punctures; the occiput and thorax faintly shagreened; the median furrow of the mesoscutum distinct, but not so deeply and sharply defined, the punctures along the lateral margins large and distinct; while the antennæ, except the club, are pale brownish yellow.

Hab. St. Vincent.

Described from two female specimens.

\section{Pentastichus, gen. nov.}

Similar to Tetrastichus, Haliday, and differing only in antennal characters as follows :- 
In both sexes the antennæ are short, clavate, 8-jointed (without a ring-joint), pubescent, the joints moniliform, the pedicel being as long as the first two funicle-joints united; club stout, fusiform ; scape slender, subclavate, inserted below the middle of the face, a little below an imaginary line drawn from the base of each eye. Frons deeply impressed; the anterior ocellus situated in the furrow, the lateral ocelli closer to the front ocellus than to the eye-margin. Thorax short, oval or almost round; the mesonotum about twice as wide as long, with three grooved lines; the scutellum semicircular, convex, with two grooved lines; metathorax very short, rounded. Wings broad, weil fringed, with the venation as in Tetrastichus. Abdomen ovate, sessile or subsessile; the first and second body-segments the longest, about equal, the following shorter.

Pentastichus xanthopus, $\mathrm{sp} . \mathrm{n}$.

o 9 . Length 0.8 to 1 millim. Aneous black, smooth, impunctured; antennæ and legs lemon-yellow; wings hyaline, ciliated; abdomen ovate in female, pointed at apex, and as long as the head and thorax united; in male rounded at apex, scarcely as long as the thorax.

Hab. St. Vincent.

Described from two male and four female specimens.

Report on the Parasitic Cynipidæ, part of the Braconidæ, the Ichneumonidæ, the Proctotrypidæ, and part of the Chalcididæ.-Part III. By William H. Ashmead.

\section{Family PROCTOTRYPID丑.}

\section{Subfamily Bethylina.}

\section{EPYRIs, Westwood.}

Two species, both males, may be distinguished as follows :-

Mesonotal furrows distinct.

Anterior coxæ and hind coxæ and femora black or piceous, rest of the legs brownish yellow ; scape and pedicel yellow, the pedicel small, rounded; flagellum brown, the joints at least twice as long as thick $\ldots \ldots \ldots \ldots \ldots \ldots \ldots \ldots \ldots \ldots \ldots \ldots \ldots$ E. insularis, sp.n. 
Mesonotal furrows almost obliterated, with only slight traces anteriorly.

Legs, including coxæ, rufous, the tarsi paler; antennæ brown, fuscous or black toward tips; pedicel more than twice as long as thick, the joints of the flagellum fully thrice as long as thick. E. incertus, sp. n.

Epyris insularis, sp. n.

c. Length $2 \frac{1}{2}$ millin. Black, shining, densely and very finely punctulate, covered with a sparse pubescence; mandibles, scape and pedicel, tegulæ and legs, except anterior coxæ and the hind coxæ, and sometimes the posterior femora, which are black or fuscous, brownish yellow. Eyes hairy. The mandibles are curved and rather slender, not broadened at tips, the tips truncate and with five minute teeth. Antennæ 13-jointed, filiform, acuminate towards tips, extending to the middle of the abdomen; flagellum fuscous, the pedicel very small, rounded, the first flagellar joint a little longer than the second, thrice as long as thick, the following twice as long as thick. The dorsum of the pronotum is trapezoidal, anteriorly and along the sides distinctly margined; mesonotum longer than the dorsum of the pronotum, with two distinct furrows and a grooved line on the scapulæ; scutellum with a furrow across the base; metathorax quadrate, the apex abruptly truncate, the sides and the truncature finely striated; the dorsum is margined along the sides and at apex, with a medial carina extending on to the truncature, its surface very finely transversely striated. Wings subhyaline, pubescent, the nerves brown; the transverse medial nervure is curved outwardly. Abdomen scarcely as long as the thorax, black, polished, sparsely pubescent, especially towards the tip; the third segment is twice as long as the fourth.

Hab. St. Vincent.

Described from four specimens.

Epyris ingertus, sp. $\mathrm{n}$.

o. Length $2 \frac{1}{2}$ millim. Black, shining, very finely microscopically punctate, the surface appearing almost smooth, sparsely pubescent; mandibles, scape and base of flagellum, and legs, including all coxæ, brownish yellow. Eyes faintly pubescent or almost bare. The mandibles are closely folded under the overlapping labrum, and the number of teeth cannot be made out, but the outer tooth is long and acute. Antennæ 13-jointed, nearly as long as the body, cylindrical, pubescent, the flagellum being fuscous or black towards the tip; the pedicel is fully twice 
as long as thick; first flagellar joint a little longer than the pedicel and slightly stouter than the second or the third; the joints beyond are all longer than the first and a little more than thrice as long as thick. The dorsum of the pronotum is a little longer than the mesonotum, margined anteriorly only, the sides rounded; mesonotum with slight traces of the parapsidal furrows anteriorly; scutellum with a transverse furrow at base; metathorax quadrate; the truncature and sides striate; the dorsum has a medial carina that extends only to the upper edge of the truncature, and with a short carina on each side at base, its surface being finely transversely striate. Wings hyaline or subhyaline, pubescent, the venation brown; the transverse medial nervure is oblique, curved outwardly. Abdomen polished black, the third segment the longest, not more than: one third longer than the fourth.

Hab. St. Vincent.

Described from five specimens. The absence of distinct mesonotal furrows causes doubt in my mind as to its being a genuine Epyris.

\section{ISOBRACHIUM, Förster.}

The two species recognized in this genus may be thus distinguished :-

Mesonotal furrows indicated only anteriorly ........

2.

Mesonotal furrows complete.

Metathorax finely rugulose; legs yellowish white; flagellum fuscous or brown; first flagellar joint four times as long as the pedicel and? little longer than the second, the joints beyond thrice as long as thick ....................

2. Metathorax finely sculptured, the sides almost I. collinum, sp. $\mathrm{n}_{\text {。 }}$ smooth.

Legs yellowish white; flagellum fuscous; pedicel rounded, not half the length of the first flagellar joint, the joints beyond the second two and a half times as long as thick

I. albipes, sp. $\mathrm{n}$.

IsOBRACHIUM COLLINUM, sp. n.

o. Length 2 to $3 \frac{1}{2}$ millim. Black, shining, with sparse, distinct punctures; mandibles and antennæ pale ferruginous, the latter fuscous towards the apex ; the depression above on collar usually pale or yellowish; legs, including coxæ, yellowish white or pale honey-yellow. Head across the eyes fully as wide as long; the eyes prominent, faintly pubescent. Mandibles broadened at tips, 5-dentate, the outer tooth long, acute, the second a little 
shorter, the three following very small, about equal. Antennæ 13-jointed, filiform, tapering toward tips, extending to the base of the metathorax; scape curved, clavate, the length of the eye; pedicel small, rounded; first flagellar joint longer than the second, three and a half times as long as thick, the following joints thrice as long as thick. Pronotum finely transversely striated or closely minutely punctulate, the depression in collar above usually yellowish, rarely entirely black, the posterior margin tinged with piceous. Mesonotum with two distinct furrows. Scutellum with a profound fovea at base. Metathorax twice as long as wide, roundedly truncate posteriorly, dorsally rugulose, with an indistinct median carina and carinated along the superior edges of the sides. Tegulæ white or yellowish. Wings subfuscous, pubescent, the venation brown; the transrerse medial nervure is oblique, and there is a more or less distinct, rhomboidal discoidal cell; the radial vein is very long. Abdomen oblong-oval, depressed, subpetiolated, black or dark piceous, banded or tinged with rufous.

$H a b$. St. Vincent.

Described from three specimens.

\section{IsOBRACHIUM ALBIPES, sp. $\mathrm{n}$.}

o. Length $2 \frac{1}{5}$ millim. Black, shining, at the most very faintly microscopically punctulate; mandibles and antennæ brown, the latter fuscous toward the tips; legs pale, whitish yellow or honey-yellow. The mandibles are broadened and truncate at apex, the two outer teeth acute, followed by three or four minute, blunt denticulations. Antennæ 13-jointed, extending to base of abdomen; pedicel very small, rounded, less than half the length of the first flagellar joint; the first flagellar joint about thrice as long as thick, the following two and a half times as long as thick. Thorax elongate, the prothorax triangular, a little longer than the mesonotum, the latter with traces of the furrows only anteriorly. Scutellum with a transverse fovea at base. Metathorax twice as long as wide, finely, faintly, transversely rugulose, the truncature rounded off, not margined above. Wings subhyaline, the venation brown; the transverse medial nervure is oblique, and the discoidal cell is only partially defined. Abdomen oblong-oval, depressed, more or less tinged with piceous.

Hab. St. Vincent.

Described from four specimens, captured at from 1000 to 2000 feet altitude. 


\section{Dissomphalus, Ashmead.}

This genus is allied to Isobrachium, Förster, and is described in my 'Monograph of the North-American Proctotrypidæ.' As the work has not yet appeared, I give here the essential characters for the recognition of the genus :-

Maxillary palpi 4-jointed; labial palpi 3-jointed. Mandibles 3-dentate. Antennæ 13-jointed, filiform, submoniliform, the first flagellar joint always smaller than the second, the joints beyond submoniliform. Mesonotum with or without furrows. Wings with two basal cells of an equal length; the transverse medial nervure straight; parastigma not developed ; the stigma oblongquadrate, the radial vein very long. Legs slender, the femora not much swollen. Abdomen oblong-oval or oval, depressed, subpetiolate; the second segment is always much longer than the third, and bears two warty-like tubercles or nipples, which are variously situated, often placed in a fovea or surrounded by a grooved line.

The two warty-like tubercles or nipples, on the second abdominal segment, are a unique character, and with the other characters mentioned will readily distinguish it from all other genera in the Bethylina.

The four species from St. Vincent may be thus tabulated :-

Mesonotal furrows wanting or with only traces anteriorly $\ldots \ldots \ldots \ldots \ldots \ldots \ldots \ldots \ldots$.

Mesonotal furrows complete, distinct.

Metathorax rugose, with a medial carina.

Transverse medial nervure straight.

Legs reddish yellow.

Second abdominal segment with two hairy tubercles in foveæ towards the base, widely separated; flagellum fuscous towards the tip, the pedicel oval, larger than the first flagellar joint, the second and the joints beyond longer than the first, about one and a half times as long as thick.

Metathorax almost smooth above, the sides D. tuberculatus, sp. and face of the truncature finely sculptured. Legs honey-yellow.

Second abdominal segment with two tubercles close together; flagellum fuscous, the pedicel larger than the 
first flagellar joint, the joints beyond quadrate, a little longer towards the

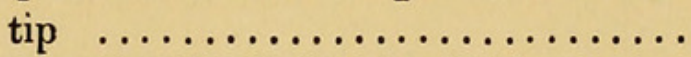

D. bisulcus, sp. n.

2. Polished, impunctured; legs, scape, and pedicel honey-yellow ; the second abdominal segment with the tubercles widely separated, placed near the lateral margin.

Flagellum filiform, submoniliform, the first flagellar joint very small.

Transverse medial nervure nearly straight, slightly curved at tip.

Flagellar joints after the first scarcely longer than thick $\ldots \ldots \ldots \ldots \ldots$.

D. confusus, sp. $\mathrm{n}$.

Transverse medial nervure straight.

Flagellar joints after the first twice as long as thick $\ldots . . . \ldots \ldots \ldots \ldots$. . .

D. politus, sp. $\mathrm{n}$.

\section{Dissomphalus tuberculatus, sp. $n$.}

o. Length $2 \frac{1}{2}$ millim. Polished black, shining, very faintly microscopically punctulate, the head with some larger scattered punctures. Mandibles and antennæ pale ferruginous, the latter fuscous towards tips. Legs reddish yellow. Head as broad as long; the eyes prominent, oblong oval, bare. Antennæ 13jointed, filiform, extending to the base of the metathorax, covered with a short pubescence; scape slightly curved, two thirds the length of the eye; pedicel oval, a little longer than the first flagellar joint; the second flagellar joint and the joints beyond longer than the first, about one and a half times as long as thick. Pronotum contracted anteriorly into a rounded neck, the contracted portion finely transversely striated, the posterior portion very short, about one third the length of the mesonotum ; mesonotum with two distinct parapsidal furrows and a grooved line on the scapulæ. Scutellum with a long transverse furrow at base. Metathorax scarcely longer than wide, roundedly truncate posteriorly, coarsely rugose, with a medial carina. Tegulæ yellowish. Wings subhyaline, pubescent, the venation brown; the transverse medial nervure is straight, and there are indications of a discoidal cell. Abdomen oval, depressed, subpetiolate, polished black; the suture between the first and second segments is very strongly arcuate; the second segment is fully twice as long as the third and bears two, widely separated, rounded, hairy nipples or tubercles, in foveæ below its middle; the third and following segments about of an equal length. 
Hab. St. Vincent.

Described from six specimens.

\section{Dissomphalus bisuleus, $\mathrm{sp} . \mathrm{n}$.}

o. Length 2 millim. Black, shining; prothorax very faintly and finely punctulate; metathorax very finely sculptured, the apex of the dorsum nearly smooth, its base with traces of two or three carinæ; sides and truncature bounded by a carina. Mesonotum with two distinct furrows. Scutellum with a transverse impressed line at base. Mesopleura with a crenate furrow across the middle. Antennæ 13-jointed, fuscous, yellowish at base, the pedicel longer than the first flagellar joint, the joints beyond quadrate, a little longer towards the tip of the flagellum. Wings hyaline, pubescent, the venation brown; the transverse medial nervure is straight, the discoidal cell indistinct and incomplete. Legs honey-yellow. Abdomen oblong-oval, smooth, shining; the two nipples on the second segment placed a little below the middle and close together, almost touching each other.

Hab. St. Vincent.

Described from three specimens.

\section{Dissomphalus confusus, $\mathrm{sp} . \mathrm{n}$.}

0 . Length $1 \frac{4}{5}$ millim. Polished black, impunctured; the metathorax very faintly punctulate, with a delicate medial carina towards base. Scape, pedicel, and legs honey-yellow or pale brownish yellow, the flagellum fuscous. Antennæ 13-jointed, filiform, submoniliform, extending slightly behind the tegulæ; the scape is more than four times as long as the pedicel, curved, and a little incrassated towards the tip; pedicel twice as long as the first funicle-joint; the first funicle-joint is the smallest, the following submoniliform, scarcely longer than thick. Prothorax triangular, about as long as the mesonotum, the latter with only slight traces of the parapsidal furrows anteriorly. Scutellum with a transverse furrow at base. Mesopleura with a curved furrow across the middle. Wings hyaline, the venation brown, the transverse medial nervure nearly straight, being very slightly curved inwardly at the apex or hind angle of the basal cell. Abdomen oblong-oval, depressed, black, shining, subpetiolate, the second segment not much longer than the third, with the two nipples placed wide apart towards the lateral margins.

Hab. St. Vincent. 
Described from a single specimen taken at an altitude of 1500 feet.

\section{Dissomphalus politus, sp. n.}

o. Length $1 \frac{4}{5}$ millim. Polished black, impunctured; metathorax roundedly truncate behind, polished, with a dorsal medial carina and very faintly sculptured at base. Scape, pedicel, and legs honey-yellow, the flagellum brown or fuscous. Antennæ 13-jointed, filiform, extending to the base of the metathorax; scape more than four times as long as the pedicel; the pedicel oval, a little longer than the first funicle-joint; the first funiclejoint the shortest, the joints beyond the second about twice as long as thick, the last thrice as long. Mesonotum without a trace of a furrow, or so faint as to be discernible only in a certain light. Wings hyaline, very slightly tinged, the venation brown; the transverse medial nervure is straight, the discoidal cell indistinctly defined. Abdomen oblong-oval, depressed, black or with a piceous tinge, the second segment longer than the third, with two minute nipples, widely separated, and placed near the lateral basal angles.

Hab. St. Vincent.

Described from two specimens captured at 1500 feet altitude.

\section{Goniozus, Förster.}

Three distinct species in this genus are in the collection and may be thus tabulated :-

The backward-directed branch of the basal nervure prolonged, joining the apex of the transverse medial nervure, and forming a small, closed, subtriangular discoidal cell.

Coxæ and femora black; tibiæ and tarsi honey-yellow .................

Coxæ and legs entirely honey-yellow ...... The backward-directed branch of the basal G. nigrifemur, sp. n. G. Sancti-Vincenti, sp.n. nervure ending abruptly, and not forming a small discoidal cell.

Coxæ and femora black; trochanters, tibiæ, and tarsi honey-yellow ........... G. incompletus, sp. $\mathrm{n}$.

Goniozus nigrifemur, sp. n.

ㅇ. Length 2 to $2 \frac{1}{2}$ millim. Polished black, at most faintly indistinctly punctate, except the head, which exhibits a few 
scattered punctures, and the sides and truncature of the metathorax, which are finely minutely sculptured. Anteunæ 13jointed, brownish yellow, hardly longer than the oblong head, moniliform, tapering at tips, the flagellar joints a little longer than wide, the first joint the smallest. Scutellum without a transverse furrow or fovea at base, separated from the mesonotum only by a delicate straight impressed line. Mesopleura with a round fovea at the middle. Dorsum of metathorax polished, without carinæ. Wings hyaline, the costa, parastigma, and stigma piceous, the nervures pale; the branch of the basal nervure curved backwards and joining the transverse medial nervure near its apex, forming a small subtriangular discoidal cellule. Legs black, the tibiæ and tarsi honey-yellow.

Hab. St. Vincent.

Described from twa specimens.

Goniozus Sancti-Vincenti, sp. n.

ㅇ. Length $1 \frac{1}{2}$ to $1 \frac{4}{5}$ millim. Polished black; the head and prothorax very finely, faintly, closely punctulate; antennæ and legs, including coxæ, wholly honey-yellow. The joints of the flagellum, after the first, are moniliform, fully as long as wide; otherwise, except in the colour of the legs, it agrees with G. nigrifemur.

Hab. St. Vincent.

Described from six specimens.

\section{Goniozus incompletus, sp. $n$.}

․ Length $2 \frac{1}{5}$ millim. Polished black; the head and thorax very finely, faintly punctulate; mandibles, antennæ, except tips, trochanters, tibiæ, and tarsi honey-yellow ; rest of the legs black. The antennæ are a little less than twice as long as the head, the flagellar joints, after the first, distinctly longer than wide. Wings hyaline; costa, parastigma, and stigma dark brown, the veins hyaline; the branch of the basal nervure ending abruptly, not curving backwards and forming no discoidal cell ; otherwise it resembles G. nigrifemur.

Hab. St. Vincent.

Described from a single specimen. 


\section{Subfamily Dryinine.}

\section{Labeo, Haliday.}

The collection represents two distinct species in this genus, although they are closely related and difficult to separate.

The following characters may, however, be used to separate them :-

Black, shining; all coxæ black, the anterior femora, more or less, middle femora and posterior femora and tibiæ brown or fuscous, trochanters, knees, and tarsi pale or whitish.

Antennæ not extending beyond the meta-

- thorax; the scape and pedicel nearly of an equal length ; the first flagellar joint twice as long as the pedicel, the following joints very slightly shorter, thrice as long as thick; vertex finely punctulate $\ldots \ldots \ldots \ldots \ldots$.

Black, shining; coxæ and legs pale, the middle L. Sancti-Vincenti, [sp.n. and posterior coxæ dusky basally, their femora towards base fuscous.

Antennæ extending to the middle of abdomen; the scape distinctly longer than the pedicel; the first flagellar joint nearly thrice as long as the pedicel, the second and third joints fully as long as the first, the following four times as long as thick; vertex smooth, not finely punctulate........

L. simulans, sp. $\mathrm{n}$.

\section{Labeo Sancti-Vincenti, sp. $\mathrm{n}$.}

o. Length $1 \frac{3}{5}$ millim. Black, shining, sparsely covered with a short, whitish pubescence. Head shining, but finely, minutely punctulate. Ocelli red. Eyes hairy. Mandibles and palpi white. Antennæ 10-jointed, fuscous, not extending beyond the tip of metathorax; scape and pedicel oval, about equal ; first flagellar joint twice as long as the pedicel, the following very slightly shorter, thrice as long as thick. Thorax with two furrows converging posteriorly. Mesopleura with a transverse furrow across the disk. Metathorax rounded off posteriorly, finely sculptured, opaque. Coxæ black or piceous; legs brown, all trochanters, tips of anterior femora and their tibiæ, middle of posterior knees, and all tarsi pale or whitish. Tegulæ yellowish white. Wings hyaline, the stigma brown, the veins hyaline. 
Abdomen as long as the thorax, black, more or less tinged with piceous.

Hab. St. Vincent.

Described from three specimens.

LaBeo simulans, sp. n.

o. Length $1 \frac{4}{5}$ millim. Black, shining, sparsely pubescent. Head impunctured, shining, or at the most with a few scattered punctures. Ocelli pale. Mandibles and palpi white. Antennæ 10-jointed, fuscous, extending to the middle of the abdomen; scape longer than the pedicel; first flagellar joint more than twice as long as the pedicel, the second and third joints as long as the first, the following slightly shorter, but fully four times as long as thick. Thorax smooth, shining, with two furrows converging and almost meeting at the base of the scutellum. Mesopleura faintly, sparsely punctate, with a grooved line across the middle. Metathorax shining, finely, closely punctured or sculptured. Legs pale; middle and posterior coxæ basally and their femora slightly dusky. Wings hyaline, including the stigma and venation. Abdomen black, piceous towards the base.

Hab. St. Vincent.

Described from two specimens.

\section{Subfamily Ceraphronina.}

\section{Ceraphron, Jurine.}

This group is poorly represented in the collection, but six specimens in all having been taken. All belong to the genus Ceraphron, and represent four distinct species, which may be separated as follows:-

Mesonotum with a distinct medial grooved line..........................

2.

Mesonotum not grooved, or with only a trace of the groove anteriorly or posteriorly.

Wings fuliginous or subfuscous; scape, pedicel, first flagellar joint, and the legs brownish yellow; rest of the flagellum black or fuscous.

Female with the third and fourth flagellar joints longer than wide...... Female with the third and fourth flagellar joints wida" than long ......

C. fummipennis, sp. n.

C. Sancti-Vincenti, sp. $\mathrm{n}$. 


\section{Wings fuscous.}

Female : scape and pedicel brown, the flagellum black ; legs reddish yellow.

First flagellar joint not longer than the pedicel, the second joint half the length of the first, the third and fourth quadrate $\ldots \ldots \ldots \ldots \ldots \ldots$ C. solntarius, sp. n.

Wings hyaline, scarcely tinged.

Female: scape, pedicel, and legs honeyyellow or pale brownish yellow.

First flagellar joint shorter than the pedicel, the second, third, and fourth joints transverse, quadrate ........

C. meridionalis, sp. n.

\section{Ceraphron fummipennis, $\mathrm{sp}$. $\mathrm{n}$.}

․ Length 2 millim. Polished black, impunctured, at the most with a few minute scattered punctures. Antennæ 10-jointed, gradually incrassated toward tips, the scape, pedicel, and first flagellar joint brownish yellow, rest of the flagellum black or fuscous; the flagellum is two and a half times as long as the scape ; the pedicel and first flagellar joint are elongate, the pedicel slightly the shorter; the flagellum from the second joint is gradually incrassated, the second, third, and fourth joints longer than thick ; the terminal joint fusiform and the longest joint. Thorax smooth, shining, the mesonotum with only a faint trace of the furrow posteriorly. Metathorax exceedingly short, with a blunt tooth at base just behind the scutellum, and toothed posteriorlateral angles. Wings fuliginous, the venation dark brown; the radial vein long, curved, about thrice as long as the linear marginal vein. Abdomen one half longer than the head and thorax together, pointed at apex, highly polished, and with striæ at base.

The male, or what is supposed to be the male, is $1 \frac{1}{2}$ millim. long, and differs from the female only in the antennæ; these are longer than the body, filiform, the flagellum black, the first and last joint slightly longer than the others, the intermediate joints being about thrice as long as thick.

\section{Hab. St. Vincent.}

Described from a male and a female specimen.

Ceraphron Sancti-Vincenti, sp. $n$.

․ Length $1 \frac{3}{5}$ millim. Differs from the above in having paler subfuscous wings, the flagellum being only twice as long as the 
scape, the four terminal joints only distinctly black; the second flagellar joint is distinctly larger than the pedicel, and neither of these joints are so long as in C.fummipennis; the third and fourth joints are wider than long; while the mesonotal groove, although delicate, is distinct for half the length of the mesonotum posteriorly.

Hab. St. Vincent.

Described from a single specimen.

Ceraphron solitarius, sp. n.

ㅇ. Length $2 \frac{1}{2}$ millim. Resembles closely $C$. fummipennis in stature, colour of the wings, and sculpture; but the mesonotal furrow is distinct; there is a large $\mathbf{V}$-shaped fovea on the mesopleuræ, not present in that species or the others; the legs are reddish yellow, pilose; the first flagellar joint is not longer than the pedicel, and both are relatively shorter than in fummipennis. These differences are sufficient to distinguish the species.

Hab. St. Vincent.

Described from a single specimen.

Ceraphron meridionalis, sp. $\mathrm{n}$.

․ Length $1 \frac{1}{5}$ millim. Polished black, impunctured; scape, pedicel, and legs honey-yellow or pale brownish yellow; flagellum fuscous, brownish towards the base. Antennæ 10-jointed, rather slender, subclavate; scape less than half the length of the flagellum, not extending to the ocelli, slender, cylindrical; pedicel distinctly longer and stouter than the first flagellar joint; the second, third, and fourth flagellar joints transverse quadrate. Thorax highly polished, with a distinct medial impressed line. Mesopleura smooth, shining, with a few faint striæ posteriorly. Wings hyaline, the radial vein long, strongly curved. Abdomen longer than the head and thorax together, the tip pointed, curving upwards.

Hab. St. Vincent.

Described from a single specimen.

Subfamily Scelionine.

Tribe i. Telenomini.

Phandrus, Thomson.

Phanurus affinis, sp. $\mathrm{n}$.

q. Length $\frac{4}{5}$ millim. Black, shining, but very feebly minutely punctate; trochanters, knees, and tarsi white. Head quadrate, 
the frons convex, smooth. Palpi pale. Antennæ 11-jointed; scape about one third the length of the flagellum ; flagellum subclavate, gradually incrassated towards tip; pedicel longer and stouter than the first flagellar joint, its apical margin white; first flagellar joint a little longer than thick, the following submoniliform, the three or four preceding the ultimate transverse, the last ovate. Thorax oblong-oval, feebly punctate, very finely sericeous. Mesopleuræ with a smooth femoral furrow. Wings hyaline, pubescent, with rather long cilia at margins; venation pale brown, the marginal vein about half the length of the stigmal. Abdomen subfusiform, pointed, polished black, a little longer than the head and thorax together, the basal segment small, transverse, smooth, without striæ, the second very long, the following very short.

Hab. St. Vincent.

Described from two female specimens.

Comes nearest to P.ovivorus, Ashm., but that species is highly polished, impunctured, with more slender antennæ.

\section{Telenomus, Haliday.}

This genus, comprising the smallest species, and probably furnishing the greatest number of species in any one genus in the Scelionince, is well represented in the collection.

The following table will materially aid in determining the species :-

\section{Table of Species.}

\section{Females.}

Pedicel not longer than the first funicle-joint .

Pedicel longer than the first funicle-joint.

Head broadly transverse, much wider than thorax $\ldots \ldots \ldots \ldots \ldots \ldots \ldots \ldots$.

Head quadrate, not or scarcely wider than thorax.

Black.

Coxæ pale or yellow.

Legs pale yellow.

Thorax microscopically punctate; scape fuscous; second abdominal segment twice as long as wide . T. confusus, sp. $\mathrm{n}$.

Legs brownish yellow; second abdoLINN. JOURN.-ZOOLOGY, VOL. XXV. 
minal segment not twice as long as wide.

Thorax slightly impressed on disk .. Thorax not impressed, convex.

Thorax minutely wrinkled....... Thorax microscopically punctate.

Club stout, much shorter than scape Club slender, as long as the scape. Not entirely black (see male).

2. All coxæ pale or yellow.............. All coxæ black.

Head nearly three times as wide as thick antero-posteriorly.

Antennæ brown, the scape pale basally; thorax sericeous; legs yellow, femora brown $\ldots \ldots \ldots \ldots \ldots \ldots$.

3. Petiole yellow.

Head three and a half times as wide as thick antero-posteriorly.

Legs yellow ................ Petiole black.

Wings fuscous $\ldots \ldots \ldots \ldots \ldots \ldots \ldots$

Wings hyaline, rarely faintly tinged.

Head two and a half times as wide as long.

Legs and antennæ, except club, yellow ................

Head three times as wide as long.

Antennæ brown-black, the scape pale basally ...............

Head three and a half times as wide as long.

Thorax strigoso-scabrous, sericeous; legs pale honey-yellow ...... Thorax minutely punctate, sericeous;

legs brownish yellow .......

Thorax polished, impunctured; legs pale yellow ............

4. Head two and a half times as wide as long (see male).

5. Coxæ and legs yellow; wings hyaline.

Head three and a half times as wide as long; thorax minutely punctate.........

Coxæ black.

Head two and a half times as wide as long; thorax finely punctate ..........
T. impressus, sp. $\mathrm{n}$.

T. difformis, sp.n.

T. magniclavus, sp. $\mathbf{n}$.

T. cubiceps, sp. n.

3.

T. medius, sp. n.

T. flavopetiolatus, sp. n.

4.

T. meridionalis, sp. $\mathbf{n}$.

T. pygmaus, sp. n.

T. scaber, sp. n.

T. Smithii, sp. n.

T. flavicornis, sp. n. 
Head four times as wide as long; head and thorax opaque, minutely closely punctulate. T. megacephalus.

\section{Males.}

Head transverse, mucn n.der than the thorax. . Head quadrate or subquadrate, not or scarcely wider than thorax.

Thorax impressed

T. impressus.

Thorax not impressed, convex.

Coxæ pale .....................

Coxæ black.

Femora and tibiæ piceous $\ldots . \ldots \ldots \ldots$

2. Pedicel always shorter than the first flagellar joint.

Black; abdomen entirely black.

Legs pale yellow.

Head and thorax polished, impunctured.

Flagellar joints oval-moniliform $\ldots . \quad$ T. difformis.

Head smooth, the thorax microscopically punctate.

Flagellum shorter than the body ....

Flagellum longer than the body ....

Sternum, metathorax, and petiole yellow.

3. Petiole yellow.....................

Petiole black.

Wings fuscous; head two and a half times as wide as long.

Flagellar joints not very long..........

Wings subhyaline; head twice as wide as long.

Flagellar joints long $\ldots \ldots \ldots \ldots \ldots \ldots$. Wings hyaline; head three and a half times as wide as long.

Antennæ yellow, flagellar joints moniliform $\ldots \ldots \ldots \ldots \ldots \ldots \ldots$.

Antennæ, except toward base, brown, the basal flagellar joints elongate. .

2.

T. monilicornis.
T. magniclavus.

T. cubiceps.

T. pectoralis.

T. flavopetiolatus.

T. fuscipennis.

T. Sancti-Vincenti.

T. flavicornis.

T. Smithii.

Telenomus monilicornis, $\mathrm{sp} . \mathrm{n}$.

$0^{*}$. Length $\frac{4}{5}$ millim. Black, shining; thorax with some faint microscopic punctures; head transverse quadrate, twice as wide as thick antero-posteriorly, smooth and shining; eyes pubescent; mandibles piceous. The antennæ are 12-jointed, filiform-moniliform, the scape one third the length of the flagellum, the second and third joints equal, a little longer than thick, the following 
moniliform. Thorax oval, scarcely longer than wide, convex, with a microscopic pubescence. Legs black or piceous, the trochanters, base, and apex of the femora and tibiæ and the tarsi pale or yellowish. Wings hyaline, pubescent, with short cilia; the venation pale yellowish; the marginal vein about two thirds the length of the long oblique stigmal vein. Abdomen polished black, not longer than the thorax, depressed, subtruncate at apex.

Hab. St. Vincent.

Described from a single specimen.

Telenomus confusus, sp. $\mathrm{n}$.

ㅇ. Length $\frac{4}{5}$ millim. Black, shining; thorax feebly microscopically punctulate. Head transverse quadrate, highly polished. Eyes covered with a fine white pubescence. Mandibles pale. Antennæ 11-jointed, clavate; scape less than half the length of the flagellum, fuscous, yellow at base ; flagellum black, the pedicel longer than the first funicle-joint, its apical margin yellowish; second funicle-joint slightly shorter than the first; the third and fourth very small; club stout, fusiform. Wings hyaline, ciliated, the venation pale brown, the stigmal vein very oblique, terminating in a small knob. Legs brownish yellow. Abdomen as long as the thorax, subtruncate at apex, black, shining, the petiole transverse, striated, the second segment about twice as long as wide at apex.

Hab. St. Vincent.

Described from a single specimen.

Telenomus impressus, $\mathrm{sp} . \mathrm{n}$.

o 우. Length $\frac{3}{5}$ millim. Black, shining; head quadrate, scarcely wider than the thorax, highly polished; thorax oval, always impressed dorsally; legs and antennæ, except the club which is brown, yellow. Antennæ 11-jointed; scape a little longer than half the length of the flagellum; pedicel twice as large as the first funicle-joint, the funicle-joints all very small; club 5-jointed, fusiform, the four basal joints transverse. Wings subhyaline, pubescent, ciliated. Abdomen oblong, as long as the thorax, polished black, the first segment finely striated, sometimes piceous, the second one and a half times as long as wide.

The male differs only in the antennæ; these are 12-jointed, filiform-moniliform, not quite as long as the body; the pedicel much longer than the first flagellar joint; the second and third 
flagellar joints minute, the following to the last loosely articulated, transverse moniliform, the last twice as long as the penultimate.

Hab. St. Vincent.

Described from one male and six female specimens.

\section{Telenomus difformis, $\mathrm{sp}$. $\mathrm{n}$.}

o 9 . Length $\frac{4}{5}$ millim. Polished black; head subquadrate, not more than twice as wide as thick antero-posteriorly; thorax ovoid, its dorsum alutaceous; legs honey-yellow. Antennæ 11jointed, as long as the body, the scape and pedicel brownish yellow, the flagellum brown-black; pedicel longer than the first funicle-joint; the second and third funicle-joints shorter than the first; club 5-jointed, slender, the basal joint transverse, the second, third, and fourth a little longer than wide, the last ovate. Wings hyaline, ciliated, the venation brown, the marginal vein very short. Abdomen as long as the thorax, the second segment longer than wide at apex.

The male differs only in the antennæ, which are 12-jointed, filiform, submoniliform, longer than the body, the scape yellow, the flagellum fuscous ; the first flagellar joint is longer than the pedicel; the second, third, and fourth shorter, more slender, and about of an equal length ; remaining joints, except the last, ovalmoniliform, covered with short white hairs.

Hab. St. Vincent.

Described from one male and one female specimen.

The left eye in the female is covered at base by the surface of the cheek, making it slightly smaller than the right.

\section{Telenomus magniclatus, sp. $\mathrm{n}$.}

o 9 . Length $\frac{4}{5}$ millim. Polished black; head quadrate, scarcely wider than the thorax; mandibles and palpi pale; legs pale brownish yellow. Antennæ 11-jointed, short, the flagellum only about one and a balf times as long as the scape; the club very stout, much shorter than the scape, black; rest of the antennæ brownish yellow; the pedicel is a little longer than the first funicle-joint, the remaining joints about equal, moniliform ; the first joint of the club is much narrower than the second, the third fully twice as wide as long, the last ovate. Wings hyaline, the venation pale brown, the marginal vein short. Abdomen a little longer than the thorax, narrowed at base. 
The antennæ in the male are 12 -jointed, filiform, hairy, a little longer than the body, pale brownish, the scape and pedicel yellow; the pedicel is a little shorter than the first flagellar joint; the first and second flagellar joints about equal, two and a half times as long as thick; the third very little shorter, the following oval-moniliform, the two preceding the last round, the last conic. The head is quadrate, the eyes very large, occupying the whole side of the head. Otherwise it agrees with the female.

Hab. St. Vincent.

Described from one female and one male specimen.

\section{Telenomus cubiceps, $\mathrm{sp} . \mathrm{n}$.}

ㅇ. Length $\frac{3}{5}$ millim. Black; head quadrate, highly polished, impunctured; thorax closely microscopically punctate, subopaque, with a dull sericeous pubescence; legs brownish yellow ; antennæ brown-black, the scape yellow. Antennæ 11-jointed, the scape - less than half the length of the flagellum; the pedicel not or scarcely longer than the first funicle-joint; the first and second funicle-joints about equal, longer than thick, and a little shorter than the first; fourth joint small, rounded; the club is slender, fusiform, 5-jointed, the three middle joints quadrate, the last hardly longer than the penultimate. Wings hyaline, ciliated, the venation brown, the marginal vein punctiform. Abdomen as long as the thorax, the second segment about twice as long as wide at apex.

The antennæ in the male are longer than the body, 12jointed, black, hairy; the first flagellar joint about twice as long as the pedicel, the remaining joints, except the last, oval, about twice as long as thick, the last fusiform, nearly twice as long as the penultimate.

Hab. St. Vincent.

Described from one male and one female specimen.

\section{Telenomes pectoralis, sp. $\mathrm{n}$.}

o. Length $3 \frac{1}{2}$ millim. Head and abdomen black, polished; thorax brownish piceous ; metathorax, sternum, petiole, and legs yellow. The antennæ are 12-jointed, filiform-moniliform, the scape yellow, the flagellum brown; the first and second flagellar joints are about equal, longer than the pedicel; the joints after the third loosely articulated, round. Wings byaline, the venation yellow, the marginal rein one third the length of the stigmal. 
Abdomen, except the petiole, polished black, shorter than the thorax, the petiole yellow, striated, the second segment a little longer than wide at apex.

Hab. St. Vincent.

Described from a single specimen.

Telenomus medius, $\mathrm{sp} . \mathrm{n}$.

ㅇ. Length $\frac{4}{5}$ millim. Black, shining; thorax sericeous; legs honey-yellow, the femora brownish, all coxæ black. The head is about thrice as wide as thick antero-posteriorly, the eyes with a white pubescence. Antennæ 11-jointed, brown, the scape yellowish towards the base, half the length of the flagellum; pedicel about twice as long as the first funicle-joint; second funicle-joint scarcely shorter than the first, both, however, a little longer than thick; third and fourth moniliform; club 5 -jointed, the three middle joints transverse, about equal, the last conic. Wings hyaline, pubescen', the venation brown, the marginal vein half the length of the stigmal. Abdomen very little longer than the thorax, polished black, the first segment striate, the second scarcely longer than wide at apex.

Hab. St. Vincent.

Deseribed from a single specimen.

Telenomus flatopetiolatus, sp. n.

o 오. Length $\frac{4}{5}$ millim. Polished black, impunctured; head three and a half times as wide as thick antero-posteriorly; scape, mandibles, and legs pale yellow; flagellum brown-black. Antennæ 11-jointed, the scape longer than half the length of the flagellum; pedicel stouter and longer than the first funiclejoint, yellowish at tip ; first funicle-joint a little longer than thick; the three following not longer than thick, the last two transverse, small ; club 5-jointed, slender, the first joint scarcely longer than the last joint of the funicle, the second larger, the third and fourth equal, quadrate, the last conic. Wings hyaline, ciliate, the venation brown, the marginal vein only one third the length of the stigmal. Abdomen very short, broadly oval, two thirds the length of the thorax, black, the petiole yellow, the third segment shorter than its width at apex.

The anteunæ in the male are 12 -jointed, filiform, pubescent, the pedicel small, rounded; the first flagellar joint stouter than the following and much larger than the pedicel; it as well as the following joint are longer than thick, those beyond the third 
moniliform, loosely articulated, the last conic, a little longer than the penultimate.

Hab. St. Vincent.

Described from five female and seven male specimens.

Telenomus neridionalis, $\mathrm{sp} . \mathrm{n}$.

9. Length $\frac{4}{5}$ millim. Polished black, the thorax sericeous. Head about two and a half times as long as thick antero-posteriorly. Antennæ 11-jointed, yellow, the 5-jointed club black; pedicel longer than the first funicle-joint, the latter longer than thick; second funicle-joint a little transverse, shorter than the first; third and fourth minute, rounded ; club-joints, except the last, subquadrate, the last ovate. Wings hyaline, the venation yellow, the marginal vein about one third the length of the stigmal. Legs pale yellow. Abdomen not longer than the thorax, polished black, the first segment striate, the second longer than wide at apex.

Hab. St. Vincent.

Described from a single specimen.

Telenomus Pygmzus, sp. n.

o ㅇ. Length $\frac{1}{2}$ millim. Polished black, impunctured; head thrice as wide as thick antero-posteriorly; eyes covered with a white pubescence; antennæ and legs brown, the tarsi white. Antennæ 11-jointed; pedicel longer and stouter than the first funicle-joint, its apical margin yellow ; second and third funiclejoints small, the fourth and fifth very minute, transverse; club fusiform, the joints, except thelast, transverse quadrate. Wings hyaline, ciliated, the venation pale brown, the marginal vein about two thirds the length of the stigmal. Legs brown, the trochanters and tarsi white. Abdomen very little shorter than the thorax, black, polished, the second segment a little shorter than its width at apex.

The male antennæ are 12 -jointed, brown, pubescent, the pedicel very slightly longer than the first flagellar joint, the second smaller than the first, the following to the last loosely joined, transverse moniliform, the last ovate, a little longer than the penultimate. Legs whitish yellow.

Hab. St. Vincent.

Described from a single specimen in both sexes.

Telenomes scaber, sp. $\mathrm{n}$.

․ Length $1 \frac{1}{5}$ millim. Head, scutellum, and abdomen polished 
black, impunctured; thorax strigoso-scabrous, sericeous ; metathorax rugoso-punctate. Head three and a half times as wide as thick antero-posteriorly. Mandibles yellow. Antennæ 11jointed, the scape and funicle yellow, the club black; the scape is half as long as the flagellum; pedicel one third longer than the first funicle-joint; the second funicle-joint shorter than the first, third and fourth transverse, the fourth the wider ; club 5 -jointed, fusiform, the basal joint as wide as the second, the following two subequal in width, nearly twice as wide as long, the last conic. Wings hyaline, pubescent, the venation pale yellow, the marginal vein less than half the length of the stigmal. Legs, including coxæ, pale honey-yellow. Abdomen oval, as long as the thorax, the first segment striated, the second hardly longer than wide at apex.

Hab. St. Vincent.

Described from a single specimen. The sculpture of the thorax is quite distinct from all the other species, and will alone distinguish it.

Telenomus Smithit, $\mathrm{sp} . \mathrm{n}$.

o 9 . Length $\frac{4}{5}$ millim. Polished black, the thorax minutely punctate, sericeous. Head about three and a half times as wide as long. Mandibles pale. Antennæ 11-jointed, the scape longer than half the length of the flagellum, brown, the club black; pedicel one third longer than the first funicle-joint, yellow at tip ; second funicle-joint shorter than the first, third and fourth very small, rounded, the fourth the smaller; club 5-jointed, the first joint narrower and shorter than the second, the second, third, and fourth quadrate, the second slightly the widest, the last conic. Wings hyaline, pubescent, the venation pale brown, the marginal vein punctiform. Legs, including coxæ, yellow or brownish yellow. Abdomen as long as the thorax, polished black, the first segment striate, the second a little longer than its width at the apex.

The male antennæ are 12-jointed, filiform, hairy, as long as the body; the scape, pedicel, and three basal joints of flagellum yellow, the remaining fuscous or dark brown; the scape is only about one fourth the length of the flagellum; pedicel small, rounded; the three basal joints of flagellum elongate, the first about twice as long as thick, the others longer, the third narrowed basally and a little curved ; remaining joints to the last moniliform, subpedicellate, the last conic. 
Hab. St. Vincent.

Described from one male and six female specimens.

Telenomus flavicornis, $\mathrm{sp} . \mathrm{n}$.

o 9 . Length $\cdot 80$ millim. Polished black, impunctured. Head three and a half times as long as thick antero-posteriorly. Antennæ 11-jointed, brown, the scape beneath yellow ; the flagellum is twice as long as the scape; pedicel a little longer than the first funicle-joint; the second a little longer than the first; third and fourth transverse moniliform, a little wider than the preceding joints; club fusiform, the first joint the shortest and narrowest, the second the longest and widest, quadrate, the third and fourth subequal, quadrate, the last conic. Wings hyaline, pubescent, the venation pale, the marginal vein punctiform. Legs pale yellow. Abdomen not longer than the thorax, polisheả black, the second segment scarcely longer than its width at apex.

The antennæ in the male are 12-jointed, yellow, very slightly dusky at tips, filiform-moniliform, a little longer than the body; the pedicel is shorter and not quite as thick as the first flagellar joint ; the first and third flagellar joints about equal; the second a little longer ; all the joints loosely articulated, hairy ; the last conic, twice as long as the penultimate, the three or four preceding joints round.

Hab. St. Vincent.

Described from one male and one female specimen.

Telenomus fuscipennis, sp. $\mathrm{n}$.

o. Length $\frac{4}{5}$ millim. Polished black, impunctured. Head about two and a half times as wide as thick antero-posteriorly. Mandibles piceous. Antennæ 12-jointed, filiform, pubescent, a little longer than the body, black; the scape brownish yellow; the pedicel is shorter than the first flagellar joint, the latter the stoutest joint of all, twice as long as thick; the second the longest, fully thrice as long as thick; the two following subequal, shorter than the third; remaining joints, except the last, long oval, twice as long as thick ; the last long, fusiform, about two and a half times as long as the penultimate. Wings fuscous, the venation brown, the marginal vein half as long as the stigmal. Legs brownish yellow. Abdomen polished black; the first segment striate, the second scarcely longer than its width at apex.

Hab. St. Vincent.

Described from a single specimen. In the fuscous-coloured 
wings and the relative length of the antennal joints this species is quite distinct from all the others.

\section{Telenomus Sancti-Vincenti, sp. $n$.}

o 9 . Length 1 millim. Black, shining, the head and abdomen polished; the thorax minutely but distinctly punctate, sericeous. Head three and a half times as wide as thick anteroposteriorly. Mandibles pale rufous. Antennæ yellowish, the six terminal joints fuscous or black; the scape is longer than half the length of the flagellum; pedicel as long as the first funiclejoint but not so thick; second and third funicle-joints subequal, shorter than the first; fourth small, round, about half the length of the third, but narrower; club 5-jointed, rather slender, the last joint conic, the preceding joints very little wider than long. Wings hyaline, the venation pale, the marginal vein about two thirds the length of the stigmal. Legs brownish yellow. Abdomen not longer than the thorax, the second segment not or scarcely longer than wide at apex.

The head in what is taken to be the male of this species is only twice as wide as thick antero-posteriorly ; the antenuæ 12 -jointed, filiform, pilose, much longer than the body, black, with the scape yellow ; the pedicel is small, not quite half the length of the first flagellar joint; the flagellar joints are all long, cylindrical, the second being the longest joint, about four times as long as thick, the last fusiform; wings subfuscous.

Hab. St. Vincent.

Described from one female and one male specimen.

Telenomus nigrocoxalis, sp. $n$.

ㅇ. Length about $\frac{4}{5}$ millim. Polished black, the thorax minutely punctate, sericeous. Head two and a half times as wide as long antero-posteriorly. Mandibles pale brown. Antennæ 11-jointed, brown, becoming black toward apex, the scape yellowish; the scape is longer than half the length of the flagellum ; pedicel longer and thicker at the tip than the first funiclejoint, the following joints to the club subequal, the last rounded ; club 5-jointed, rather slender, the first joint longer than wide, the three following quadrate, the last conic. Wings hyaline, pubescent, the venation pale brown, the marginal vein scarcely half the length of the stigmal. Legs brownish yellow, with all the coxæ black. Abdomen as long as the thorax, the first segment striated, the second a little longer than wide. 


\section{Hab. St. Vincent.}

Described from a single specimen.

Telenomus megacephalus, $\mathrm{sp} . \mathrm{n}$.

․ Length $1 \frac{1}{5}$ millim. Black, subopaque, the head and thorax closely minutely punctulate; abdomen highly polished. The head is unusually wide, fully four times as wide as thick anteroposteriorly. Antennæ 11-jointed, brownish yellow, the club black; the pedicel is longer than the first funicle-joint; second funicle-joint shorter than the first; third and fourth transverse, subquadrate, the fourth the wider; the first four joints of the club are quadrate, the last conic. Wings hyaline, pubescent, the venation pale brown, the marginal vein punctiform. Legs brownish yellow, the coxæ black. Abdomen broadly oval, not longer than the thorax, the first segment short, very wide, striated, the second segment wider than long.

$H a b$. St. Vincent.

Described from a single specimen.

The species is remarkable for the very broad head, in this respect approaching more closely to those species which are now included in my genus Trissolcus.

\section{Trissolcus, Ashmead.}

\section{Trissoldus laticeps, sp. $\mathrm{n}$.}

․ Length 1 millim. Black, subopaque, minutely closely punctulate; scape of antennæ and legs, except coxæ and the basal two-thirds of the femora which are black, reddish yellow; tarsi yellowish. Head very broad, about four times as wide as thick antero-posteriorly; the lateral ocelli a little away from the margin of the eye and connected with it by an oblique grooved line. Thorax with three abbreviated grooved lines posteriorly; the scutellum polished. Antennæ 11-jointed, the pedicel longer than the first flagellar joint, the last two funicle-joints small, rounded; club 5-jointed, the last joint conic, the other joints transverse quadrate, about twice as wide as long. Abdomen broadly oval, polished black, not longer than the thorax; the first segment striate, the second much wider than long. Wings subfuscous, the marginal vein short.

Hab. St. Vincent.

Described from four specimens. 


\section{Tribe ii. Teleasini.}

\section{Prosacantha, Nees.}

Of this extensive genus but three species, in the male sex, are represented in the collection, which may be separated as follows :-

Black, shining.

Thorax with indications of furrows posteriorly. . 2.

Thorax entirely without furrows; legs brownish yellow ; postscutellar spine very short.

Antennæ only a little longer than the body, the flagellar joints from the fourth longer than the first, the first four times as long as thick.

Abdominal segments 1 and 2 and base of 3 striated .....................

2. Legs brownish yellow.

P. brevispina, sp. n.

Middle tarsi and two-thirds of posterior tibiæ and their tarsi fuscous; antennæ nearly twice as long as the body, the flagellar joints all long, 7 or 8 times longer than thick; wings subfuscous..............

Legs reddish yellow.

Antennæ much longer than the body, the flagellar joints about 5 times as long as thick; wings fuscous $\ldots \ldots \ldots \ldots \ldots \ldots \ldots \ldots . . \quad P$. sublineata, sp. n.

\section{Prosacantha brevispina, sp. n.}

o . Length $1 \frac{1}{2}$ millim. Black, shining, the vertex and thorax faintly, sparsely punctulate; face highly polished, with striæ along the orbits. Antennæ 12-jointed, a little longer than the body, brown-black, the basal half of scape yellowish; the first flagellar joint is very slightly longer than the second, about four times as long as thick, the second and third subequal, the fourth as long as the first, all the following longer than the first. Scutellum polished. Postscutellum punctate, its spine very short, not longer than broad at base. Legs brownish yellow. Wings hyaline. Abdomen polished, the first and second segments and the third at base striated.

Hab. St. Vincent.

Described from two male specimens. 
Prosacantha tibialis, sp. $\mathrm{n}$.

${ }^{*}$. Length $1 \frac{1}{2}$ millim. Black, shining, the vertex and the thorax sparsely punctate, the face striate. Mandibles large, rufous. Antennæ 12-jointed, nearly twice as long as the body, black, the scape pale at base; the first flagellar joint is about seven times as long as thick, the third angulated, the following a little longer. Thorax with the parapsidal furrows slightly indicated posteriorly. Scutellum polished, punetate at base. Postscutellar spine long, acute, two and a half times as long as thick at base. Legs brownish yellow, the middle tarsi and twothirds of posterior tibiæ and their tarsi fuscous ; tarsi very long and slender, much longer than their tibiæ. Wings subfuscous. Abdomen polished, the first and second segments and most of the third longitudinally striated.

Hab. St. Vincent.

Described from six male specimens.

Prosacantha sublineata, sp. $n$.

o. Tength $1 \cdot 6$ millim. Black, shining; in sculpture and colour, except the legs are wholly reddish yellow, it agrees with P. tibialis; but the antennæ are shorter and stouter, the first flagellar joint being only five times as long as thick and a little shorter than the second; the postscutellar spine is a little longer, acute ; while the striæ on the first and second abdominal segments are very coarse, the third exbibiting some faint striæ only at base.

Hab. St. Vincent.

Described from a single specimen.

\section{Acoloides, Howard.}

This genus is parasitic on spiders' eggs. The three species recognized in the collection may be tabulated as follows :-

Not entirely yellow $\ldots \ldots \ldots \ldots \ldots \ldots \ldots$.

Entirely yellow ; eyes, ocelli, and antennal club

brown-black; head very broad. $+\ldots . . \quad$ A. ochraceus, sp. n.

2. Head and thorax black.

Abdomen, scape, and legs yellow, the femora dusky above; wings hyaline, with a fuscous streak beneath the tip of the stigmal vein. o $\ldots \ldots \ldots \ldots \ldots \ldots$. .

Subfuscous; the base of abdomen, scape, and legs yellow; antennæ moniliform. $0^{*} \ldots$ A. subfuscus, sp. n. 
Acoloides ochraceus, sp. n.

․ Length 1.5 millim. Honey-yellow or brownish yellow, feebly punctulate, the abdomen finely, longitudinally striate. Head large, very broad; the eyes purplish brown, bare; ocelli black. Antennæ with the flagellum fuscous ; the club large, unjointed; the pedicel obconic, nearly as long as the first three funicle-joints united; the first funicle-joint very little longer than thick, the three following equal, transverse ; club very large, fusiform, as long as the pedicel and funicle. Wings subhyaline, the nervures fuscous ; the marginal vein punctiform, the stigmal long, thickened at base.

Hab. St. Vincent.

Described from a single specimen.

Acoloides fascipennis, sp. $n$.

ㅇ. Length 0.6 millim. Head and thorax black, subopaque, closely microscopically punctate; antennæ pale brown, tinged with fuscous; legs and abdomen brownish yellow. Wings hyaline, with a slight fuscous blotch beneath the tip of the stigmal vein, the nervures pale yellowish; the marginal vein punctiform, the stigmal long, ending in a little knob.

Hab. St. Vincent.

Described from a single specimen.

Acoloides subfuscus, sp. n.

$\delta^{*}$. Length $0 \cdot 6$ millim. Brownish, shining, faintly microscopically punctate, with a fine sericeous down; the scutellum and abdomen towards apex fuscous, the scutellum more distinctly punctate than the thorax; abdomen at base, scape, and legs brownish yellow ; flagellum brown, filiform, submoniliform, the last joint ovate. Wings subfuscous, pubescent, with long cilia, and with a slight blotch beneath the stigmal vein.

Hab. St. Vincent.

Described from a single specimen.

Possibly this may prove to be the male of $A$. fascipennis. 


\section{Tribe iii. Scelionini.}

As there are several species described in new genera, indicated in my 'Monograph of North-American Proctotrypidæ,' I give here a copy of the tables for their recognition.

\section{Table of Genera.}

Postmarginal vein wanting or never greatly developed, always shorter than the stigmal vein, the submarginal vein often never reaching the costa and terminating in a large stigma; the abdomen long, fusiform ...............

Postmarginal vein always greatly lengthened, the submarginal never terminating in a stigma.

Basal vein wanting.$\ldots \ldots \ldots \ldots \ldots \ldots \ldots$

Basal vein present.

First abdominal segment without a horn at base ........................

First abdominal segment with a horn at base.

Marginal vein short; abdomen long, pointed fusiform, the first segment narrow, petioliform, the second and third nearly equal................... Caloteleia, Westw.

Marginal vein long; abdomen long, linear or subfusiform, the first segment quadrate or subquadrate ............. Baryconus, Förster.

2. Abdomen long, pointed fusiform or linear, segments 2,3 , and 4 nearly equal.

Mesonotum with two furrows.

Metascutellum without a spine.

Metanotum with no enclosed space at base.

Marginal vein about twice the length of the stigmal.

Mandibles 3-dentate ............ Macroteleia, Westw.

Mandibles 2-dentate ........... Calliscelio, Ashm.

Metanotum with a large, semicircular enclosed space at base.

Marginal vein punctiform .......... Chromoteleia, Ashm.

Abdomen oblong-oval or fusiform, but not especially lengthened.

Metascutellum spined.

Mesonotum with two furrows.

Mandibles 2-dentate ; abdominal segments

1 and 2 equal in length, the third longer ................... Opisthacantha, Ashm. 
Mesonotum without furrows.

Mandibles 2-dentate; segments 1 and 2 equal in length, the 3 rd longer (Opisthacantha).

Mandibles 3-dentate; segments 2 and 3 equal in length, the lst shorter ..... Lapitha, Ashm.

Metascutellum not spined, simple.

Marginal vein short, or not more than

half the length of the stigmal, most frequently punctiform.

Mesonotum without furrows.

Head quadrate................ Cacus, Riley.

Mesonotum with two furrows.

Antennæ with a 6 -jointed club ......... Anteris, Förster.

Antennæ filiform, without a club ....... Apegus, Förster.

3. Mesonotum with three distinct furrows.

Metascutellum with two erect teeth ....... Hoploteleia, Ashm.

Mesonotum with two furrows.

Abdomen very long, fusiform or linear.

Metathorax unarmed; mandibles 3-dentate .................. Macroteleia, Westw.

Abdomen not very long, ovate or oblongoval.

Metathorax unarmed; mandibles 2-dentate.$\ldots \ldots \ldots \ldots \ldots \ldots \ldots$ Anteris, Förster.

Mesonotum without furrows.

Metascutellum spined (Opisthacantha).

Metascutellum simple.

Abdomen fusiform.

Abdominal segments strongly constricted; antennal club oval, 5-jointed ...... Cremastobaus, Ashw.

Abdomen broadly oval, sessile, the second segment usually a little the largest. . . Hadronotus, Förster.

4. Submarginal vein not reaching the costa, knobbed .................. Baoneura, Förster

Submarginal vein reaching the costa often by a thickened stigma.

Marginal vein very short, the postmarginal scarcely developed, or shorter than the stigmal.

Mesonotum with two furrows.......... Idris Förster.

Submarginal vein terminating in a thickened stigma.

Head without a frontal lamina or ledge ; postmarginal vein never developed $\ldots \ldots, \ldots$ IINN. JOURN.-ZOOLOGY, VOJ. XXV. 
Head with a frontal lamina or ledge.

Scutellum quadrate, the posterior angles acute; postscutellum with a large erect spine ..................... Acanthoscelio, Ashm.

Scutellum and postscutellum simple, not spined ................... Sparasion, Jurine.

5. Mesonotum with or without furrows.

Maxillary palpi short, 3-jointed.......... Scelio, Latr.

Mesonotum with two distinct furrows.

Maxillary palpi long, 5-jointed .......... Sceliomorpha, Ashm.

\section{Caloteleia, Westwood.}

This genus seems to be well represented in the West Indies and South America, and the several species recognized may be thus tabulated :-

Species pale...

2.

Species black or æneous.

Mesonotal furrows present.

Head microscopically punctate; thorax smooth, impunctured; base of first abdominal segment, legs, and antennæ, except club, yellow; vertex narrow. 오.

Head and thorax, except centrally, coarsely punctate, æneous; legs and scape [pale

brown; vertex broad. of $f$......... C. anea, sp. n.

Mesonotal furrows wanting.

Abdomen very long and pointed, in female with the lateral margins more or less yellow; legs pale yellowish; antennæ brown, the scape yellow. $\delta$ o $\ldots . .$. .

2. Mesonotal furrows wanting.

A basal nervure.

Honey-yellow, impunctured; abdominal segments 2,3 , and 4 banded with black at apex; eyes blue. $\delta$ o $\ldots . . . . . . . .$.

Brownish yellow, punctate; apex of abdomen, the $3 \mathrm{rd}$ segment and base of $4 \mathrm{th}$, and the apex of horn black; the male with the base of the 2 nd segment black ........ C. maculipennis, sp. $\mathrm{n}$.

No basal nervure.

Brownish yellow, coarsely punctate; apex of abdomen dusky; eyes and antennal club brown-black. of $q$..................

C. puncticeps, $\mathrm{sp} . \mathrm{n}$.

C. elongata, sp. $\mathrm{n}$.
C. ocularis, sp. $\mathrm{n}$.

C. punctata, sp. n. 


\section{Caloteleia puncticeps, sp. $\mathrm{n}$.}

ㅇ. Length 1.2 millim. Polished black, the head on vertex and the abdomen finely punctate; antennæ, except the club, legs, and apical half of the petiole honey-yellow. Antennæ 12jointed ; the pedicel is longer than the first funicle-joint, the first and second funicle-joints subequal, the third smaller, the fourth very minute. Thorax polished, impunctured, with two furrows. Wings hyaline, the venation yellowish, the marginal vein punctiform, the stigmal very short. Abdomen fusiform, twice the length of the thorax, the first segment striate, the horn at apex polished black; the second and third segments nearly equal in length, their extreme apical edges smooth, polished.

Hab. St. Vincent.

Described from a single specimen.

\section{Caloteleia mane, sp. $\mathrm{n}$.}

of ㅇ. Length $2 \cdot 1$ to $2 \cdot 3$ millim. Eneous black; head in female closely punctate, the cheeks alone smooth ; thorax punctate, with two furrows, more closely punctured toward the sides, the mesonotum and scutellum having a smooth impunctured space down the centre; metathorax deeply emarginate behind; scape and legs pale brownish; first funicle-joint longer than the pedicel; second shorter; third and fourth small, transverse. Wings fuscous or subfuscous, hyaline at base; the marginal vein is about half the length of the stigmal.

In the male the head and thorax are smooth, impunctured; the petiole long, fluted; the second abdominal segment and the third and following, at the sides, longitudinally striate; the metathorax is finely rugose and armed with two erect spines; antennælong, filiform, the joints loosely joined; the flagellum is black, the first joint the longest, much longer than the pedicel, more than four times as long as thick, the following joints, to the last, subequal, the third excised at base.

Hab. St. Vincent.

Described from one female and three male specimens.

\section{Caloteleia elongata, sp. $\mathrm{n}$.}

o. Length 4 millim. Black, punctate; the abdomen along the sides yellow; legs pale, whitish yellow; antennæ, except club, brownish yellow. Mesonotum without furrows. Antennit 12-jointed, the pedicel and first two funicle-joints elongated, the first one third longer than the second; third funicle-joint half the length of the second; fourth about half the length of the 
third but shorter. Wings subfuscous, the venation brown-black ; basal nervure distinct, originating from a fuscous cloud; marginal vein two thirds the length of the stigmal; stigmal vein slightly curved, terminating in a rounded stigma. Abdomen very long, pointed, about four times as long as the thorax, punctate, the first and second segments the longest, the first being slightly the longer, striate; horn not extending above the apex of scutellum.

$\delta$. Length 3 to $3 \cdot 2$ millim. Differs from female in having the abdomen entirely black, without a basal horn, the first segment being shorter than the second and but slightly longer than the third, striate; the following segments punctate and lineated except toward the sides, the second with a central carina; the antennæ are very long, filiform, brown-black, with a reddishyellow scape ; the flagellar joints are all about of an equal length, cylindrical, about five times as long as thick.

Hab. St. Vincent.

Described from two female and eight male specimens.

Caloteleia ocularis, sp. $\mathrm{n}$.

o 9 . Length $1 \cdot 1$ to $1 \cdot 5$ millim. Honey-yellow, polished, impunctured; in the female the club of antennæ, the second abdominal segment, and the apical half of the third and fourth segments are black; in the male the flagellum, apical half of the first, second, and third abdominal segments black. Eyes large, distinctly pale blue in both sexes. Wings subfuscous, with a fuscous cloud enclosing the basal nervure. Abdomen in female pointed, fusiform, about twice the length of the head and thorax together; the second segment two thirds the length of the third; the first segment striate, furnished with a horn at base that extends forwards before the apex of the scutellum, the horn being smooth and black at apex; the following segments are faintly aciculated, the second minutely granulated at the middle. Pedicel and second funicle-joint are about equal, very little longer than thick; the first funicle-joint is a little longer, about twice as long as thick, the third and fourth minute, transverse.

In the male the abdomen is but slightly longer than the head and thorax ; antennæ filiform, dusky toward tips; the scape and pedicel yellow, the latter scarcely half the length of the first flagellar joint; first and second flagellar joints about equal, shorter than the following.

Hab. St. Vincent.

Described from four female and two male specimens 


\section{CaLoteleia macUlipennis, $\mathrm{sp} . \mathrm{n}$.}

o ㅇ. Length 2.5 to 3 millim. Brownish yellow, moderately coarsely punctate; head transverse; thorax without furrows. The eyes, club of antennæ, metapleura, apex of horn, third abdominal segment, the fourth at base, and the conical last segment black. In the male the flagellum is usually fuscous, and the base of the second abdominal segment is also black, otherwise it is coloured as in the female. Wings subhyaline, with a large smoky cloud across the disk of the wing beyond the stigmal vein; basal nervure present; marginal vein about three times as long as thick; stigmal slightly curved, ending in a knob. The antennæ in the female have the pedicel longer than the second funicle-joint, the first being longer than the pedicel, third very little longer than thick, fourth quadrate. In the male the antennæ are filiform, the joints about equal, the first flagellar joint being slightly the longest. Abdomen smooth, the first and second segments striate; the first and third segments are about equal, the second longer.

Hab. St. Vincent.

Described from one female and three male specimens.

Caloteleia punctata, sp. $n$.

o ㅇ. Length $2 \cdot 1$ to $2 \cdot 5$ millim. Brownish yellow, closely rather coarsely punctate; apex of abdomen fuscous; antennal club in female black. Postscutellum in both sexes armed with two erect teeth or tubercles. In the female the pedicel and the first funicle-joint are elongate, about equal in length, the second funicle-joint only slightly longer than thick, third and fourth moniliform ; in the male the pedicel is less than half the length of the first flagellar joint, the second one third shorter than the first, the third and following joints a little longer than the second. Wings subfuscous; the marginal vein is about half the length of the shaft of the stigmal, the latter being knobbed; basal nervure wanting. Abdomen, except the first and second segments, polished, impunctured, the first and second striate, the second more finely striate than the first, and the longest segment, the first, a little shorter than the third.

Hab. St. Vincent.

Described from six male and nine female specimens. 


\section{Macroteleia, Westwood.}

From rearings of a species in America we now know that this genus is parasitic on the eggs of the orthopterous genus Orchilimum, although it may also prove to infest the eggs of other Locustidæ.

The species from St. Vincent may be thus tabulated :-

\section{Mesonotal furrows complete.}

Species not entirely black .............

2.

Species entirely black, punctate.

Abdomen very long, $3 \frac{1}{2}$ times as long as the head and thorax united; middle lobe of mesonotum with a median carina; legs and aritennæ, except the club, brownish yellow or yellow. $q$............. Abdomen only about $2 \frac{1}{2}$ times as long as the head and thorax united; middle lobe of mesonotum not carinate; legs and antennæ, except club, brownish yellow or honey-yellow .......... M. Sancti-Vincenti,sp. n.

2. Abdomen, except sometimes the tip, rufous; scape and legs brownish yellow; scutellum with a delicate median carina.......... M. erythrogaster, sp. n.

\section{Macroteleia Carinata, $\mathrm{sp}$. $n$.}

․ Length $5 \cdot 1$ millim. Black, punctate; head quadrate; antennæ brownish yellow or pale rufous, the club black. Pedicel and first funicle-joint lengthened, the latter the longer; second funicle-joint scarcely half the length of the first; third very slightly shorter; fourth transverse-quadrate. Thorax with two furrows, the middle lobe with a central carina. Legs, including coxæ, pale rufous or brownish yellow. Wings subfuscous, the marginal vein once and a half as long as the stigmal, the latter oblique, knobbed; basal nervure wanting. Abdomen very long and pointed, $3 \frac{1}{2}$ times as long as the head and thorax together, punctate and faintly aciculated, the first and second segments striate; segments 1,2 , and 3 with dorsal longitudinal carinæ towards the sides; the first segment is about half the length of the second, the following being about equal in length.

Hab. St. Vincent.

Described from a single specimen. The carinæ on the middle mesonotal lobe and the basal abdominal segments are unique in the genus, and readily distinguish the species. 


\section{Macroteleia Sancti-Vincenti, sp. $\mathrm{n}$.}

q. Length 3 to $3 \cdot 1$ millim. Black, punctate; antennæ, except the club (rarely the funicle), and legs brownish yellow or pale rufous. Thorax with two furrows; no carina on the middle lobe. Wings hyaline, the venation pale brown, the marginal not quite twice as long as the stigmal, the basal nervure wanting; tegulæ blackish. Abdomen fusiform, $2 \frac{1}{2}$ times as long as the head and thorax together, closely punctate; the second and third segments are about equal, not quite twice as long as the first ; fourth a little shorter; fifth shorter than the fourth; sixth subcompressed, longer than the fourth.

Hab. St. Vincent.

Described from five specimens.

MaCRoteleia eRYthrogaster, sp. $n$.

ㅇ. Length 3 to $3 \cdot 2$ millim. Agrees closely, structurally, with M. Sancti-Vincenti, except that the abdomen, with the exception of the compressed conical last segment which is black, is wholly rufous, the wings with a fuscous tinge, the marginal vein being only once and a half as long as the stigmal, while the scutellum has a slight median carina.

Hab. St. Vincent.

Described from eight specimens. Distinguished at once by the colour of the abdomen and by the keeled scutellum.

\section{Calliscelio, Ashmead.}

\section{Calliscelio laticinctus, sp. $\mathrm{n}$.}

우. Length 2.5 millim. Head black; face, clypeus, mandibles, and palpi pale; thorax rufous or brown, the metathorax black; legs yellowish, the posterior coxæ and femora obfuscated above. Abdomen fusiform, much longer than the head and thorax together, piceous brown, the basal one-third of the second segment and basal half of third yellow; petiole, apical two-thirds of second segment, and the last three segments black; the petiole is nearly three times as long as thick, of a uniform width throughout, and longitudinally striate; the second segment is the longest, one half longer than the first, broadened at apex to three times its width at base, its basal half longitudinally aciculated; the third two thirds the length of the second, the fourth two thirds the length of the third; fifth a little more than half the length of the fourth; sixth conical, about as long as the third. Head transverse, finely 
punctate. Antennæ 12-jointed, brownish yellow, the club black ; the first and second funicle-joints are long, cylindrical, subequal; the third two thirds the length of the second, stouter; the fourth about one half the length of third and thicker. Thorax with small sparse punctures. Wings fuscous, with the basal half and the apex hyaline; basal nervure distinct, the marginal three times as long as the oblique stigmal, the latter ending in a little knob; the postmarginal longer than the marginal.

Hab. St. Vincent.

Described from six specimens.

\section{Chromoteleia, Ashmead.}

Chromoteleia semicyanea, sp. $n$.

0 ㅇ. Length 4.5 to 5 millim. Head and thorax cyaneous punctate. Abdomen sessile, very long, pointed fusiform, ochraceous, punctate, the first and second segments striate; first segment a little more than half the length of the second; second and third long, equal ; the following segments shorter, subequal, the last two very minute. Legs yellow. Antennæ black, the scape yellow: in the female ending in a 6-jointed club; the first funicle-joint the longest, one half longer than the second and not quite twice the length of the pedicel, the third funicle-joint subequal with the second, the fourth a little longer than thick and stouter than the third: in the male subfiliform, the first flagellar joint twice the length of the pedicel, after the third the joints, except the last, about equal, less than twice as long as thick, the last long, ovate. Wings fuscous, the marginal vein punctiform, the basal nervure distinct; the stigmal slightly curved, ending in a small knob, with a slight trace of a radius.

Hab. St. Vincent.

Described from one male and one female, taken at an altitude of 2000 feet.

\section{Opisthacantha, Ashmead.}

Two species of this rare genus may be thus separated :Mesonotum without furrows.

Polished black, impunctured, the petiole yellow; it, as weil as the second abdominal segment, striate; postscutellar spine very minute.

Legs and scape honey-yellow. $+\ldots \ldots \ldots \ldots \ldots$ O. polita, sp. n. 
Mesonotum with two delicate furrows.

Brownish yellow, impunctured; metathorax and tip of abdomen obfuscated; petiole striate; the second abdominal segment smooth; postscutellar spine distinct.

Legs, scape, and pedicel yellow. of $+\ldots \ldots \ldots \ldots$ O. pallida, sp. n.

\section{Opisthacantha polita, sp. n.}

ㅇ. . Length 1 millim. Polished black; first and second abdominal segments striate; thorax without furrows; postscutellar spine minute; antennæ short, black, the scape and pedicel brown; first funicle-joint small, very little longer than thick, thinner than, and scarcely half the length of, the pedicel, the three following joints small, transverse; club large, stout. Wings subhyaline, the nervures brown; marginal vein somewhat thick, not quite as long as the slender stigmal vein; basal nervure subobsolete. Legs, including coxæ, brownish or honey-yellow. Abdomen oval, polished, the first and second segments striate, the third segment the largest, fully twice as long as the second, the first not longer than thick, shorter than the second.

$H a b$. St. Vincent.

Described from two specimens.

\section{Opisthacantha Pallida, sp. $n$.}

o. Length 1.2 millim. Pale brown; flagellum and metathorax fuscous; legs pale yellow. Head transverse, the lateral ocelli only their width from the margin of the eye; antennæ long, filiform; flagellar joints 1 and 2 scarcely twice as long as thick, the following joints to the last a little longer, the last joint one half longer than the penultimate. Thorax with two delicate but complete furrows. Postscutellar spur distinct, triangular. Wings fuscous, the basal nervure distinct, the marginal two thirds the length of the stigmal. Abdomen oblong-oval, depressed, the first three segments faintly aciculated, the first very little shorter than the second, more than twice as long as thick, the second and third about equal in length.

․ Length 1.3 millim. The antennæ terminate in a large, dusky, 6-jointed club ; the pedicel is longer than the first funiclejoint, the first and second funicle-joints subequal, scarcely longer than thick, the third quadrate, the fourth minute, transverse; 
while the abdomen is longer and more pointed than in the male.

Hab. St. Vincent.

Described from one male and one female.

\section{Lapitha, Ashmead.}

LAPITHA SPINOSA, sp. n.

ot. Length 3.5 millim. Head and thorax brownish yellow, finely and closely punctate; metathorax with oblique carinæ meeting at the base of the postscutellum; postscutellum produced into an acute spine. Legs yellow. Abdomen fusiform, extending slightly beyond the tip of the wings when folded, black, shining, closely punctate; sometimes the basal half of the third segment is yellow; first and second segments striate; the first segment is a little longer than wide, very slightly wider at apex than at base; the second and third are the longest segments, about equal in length; the fourth the length of the first; the fifth two thirds the length of the fourth; the sixth one half the length of fifth; the seventh very small, basally smooth; the eighth subtriangular, margined. Antennæ filiform, dark brown, the scape and pedicel yellow; second, third, and last joint of flagellum about equal in length; first and fourth joints about equal, shorter than the second; the joints beyond the third very slightly shorter. Wings hyaline, with a large discoidal blotch below the postmarginal vein; nervures fuscous; basal nervure distinct; marginal nervure as long as the shaft of the stigmal, the latter oblique, knobbed at the tip.

$H a b$. St. Vincent.

Described from four specimens taken at 1500 feet altitude.

\section{Cacus, Riley.}

Two species in the collection are distinguished as follows :-

Black, punctate; the apical half of abdomen in

female rufous or piceous; petiole long, striate.

Wings hyaline; scape and legs honey-yellow. o $9 . . \ldots \ldots \ldots \ldots \ldots \ldots \ldots \ldots \ldots$. insularis, sp. n.

Brownish yellow or honey-yellow, the large 3rd

abdominal segment black.

Wings hyaline, with a large smoky transverse discoidal blotch beyond the stigmal vein. $0^{\star} \ldots$ C. laticinctus, sp. $\mathrm{n}$. 


\section{Cacus insularis, $\mathrm{sp} . \mathrm{n}$.}

o 9 . Length $1 \cdot 8$ to $2 \cdot 2$ millim. Black, shining, sparsely punctate; head quadrate, the frons impressed; thorax without furrows, the metathorax with two teeth at base; legs, including coxæ, honey-yellow. Abdomen in female longer than the head and thorax together, depressed, rufous, the first two segments black, the first coarsely striate, the second finely aciculate, smooth at the sides, the following segments polished, impunctate; the second and third segments are about equal in length, the first slightly shorter, the fourth less than half the length of the third, the fifth shorter than the fourth, the sixth triangular, not longer than the fifth. In the male the abdomen is entirely black, with the second segment the longest, the petiole a little longer than the third. Antennæ in male filiform, reaching to the middle of the abdomen, in colour varying from pale brown to black, the scape always yellowish; the pedicel is very small ; the first four flagellar joints are about equal, about $3 \frac{1}{2}$ times as long as thick, the following very slightly shorter. In the female the pedicel and first funicle-joints are lengthened, the latter one third longer than the former, the second funicle-joint half as long as the first, the third scarcely longer than thick, the fourth wider than long and thicker than the third. Wings hyaline, the marginal vein less than one half the length of the stigmal; no basal nervure.

Hab. St. Vincent.

Described from 12 male and 7 female specimens.

Cacus laticinctus, sp. $\mathrm{n}$.

o. Length $1 \cdot 8$ to 2 millim. Honey-yellow, sparsely punctured; head quadrate; thorax without furrows, the metathorax with two erect teeth at base; hind coxæ, or at least basally, and the third abdominal segment black; eyes and ocelli brown-black; flagellum brown; legs yellowish white. Wings hyaline, with a large fuscous blotch across the apical disk beyond the stigmal vein; basal nervure distinct; marginal nervure scarcely half the length of the stigmal.

Hab. St. Vincent.

Described from 23 male specimens.

ANTERIs, Förster.

ANTERIS RUfipes, sp. n.

o 9 . Length 1.8 millim. Black, closely, microscopically punctate; mandibles and legs rufous; head transverse. Antennæ 
12-jointed ; in female ending in a 6 -jointed club, first funicle-joint about as large as the pedicel, 2nd, 3rd, and 4th joints moniliform, the 4th the smallest, transverse : in male filiform moniliform, the second flagellar joint and the pedicel about equal, the first flagellar joint twice as long as the pedicel, the fourth dilated, the following moniliform, loosely joined, becoming very slightly smaller toward apex, the last cone-shaped. Thorax with two delicate furrows, less distinct anteriorly in the female. Wings hyaline, the nervures dark brown, the basal nervure wanting or subobsolete; marginal nervure a little shorter than the shaft of the stigmal. Abdomen long ovate or subfusiform, a little longer than the head and thorax together, finely punctate, the first and second segments striate; the third segment is the longest; the first segment, in the female, has a triangular prominence or ridge at its base. Anterior tibiæ very short, swollen.

Hab. St. Vincent.

Described from two male and two female specimens.

\section{Cremastobeus, Ashmead.}

The two species may be thus distinguished :Wholly black, the legs yellow ............... C. niger, sp. n. Head and thorax black; abdomen rufous ......... C. bicolor, sp.n.

Cremastobeus Niger, sp. $n$.

o 9 . Length 1 millim. Black, subopaque, minutely punctate, pubescent, the thorax more lustrous than the head; antennæ brownish yellow, paler at base; legs yellow. Head subquadrate, rounded anteriorly, the lateral ocelli touching the border of the eye; the eyes pubescent. Thorax with two delicate furrows. Wings hyaline, the stigmal vein oblique, slightly shorter than the marginal vein. Abdomen long ovate, in female longer than the head and thorax together, in male slightly shorter, less pointed behind, the sutures between the segments deeply impressed, crenate or striate at bottom, the first segment longitudinally striate. The antennæ in the male are subfiliform moniliform, very slightly thickened toward tips, rust-brown; in female paler and ending in a 5 -jointed club.

Hab. St. Vincent.

Described from one female and two male specimens.

Cremastobaus bicolor, sp. $\mathrm{n}$.

․ Length $1 \cdot 1$ millim. Head and thorax black, faintly 
microscopically punctate scarcely sufficient to destroy the lustre of the surface; eyes oval, pubescent; abdomen rufous, subfusiform, longer than the head and thorax together, the segments strongly constricted at the sutures, the sutures crenate; legs yellowish. Antennæ 12-jointed, brownish yellow, the club oval-rotund, 5 -jointed, black ; the first funicle-joint is the thickest and largest joint, the following, to the club, gradually subequal, the last two rounded, a little transverse. Wings hyaline, the marginal vein a little longer than the stigmal, the latter oblique, ending in a little knob; no basal nervure.

Hab. St. Vincent.

Described from one female specimen.

\section{Hadronotus, Förster.}

So far as we know this genus is parasitic only on Hemipterous eggs. Several species are in the collection, and may be recognized by the aid of the following table:-

Species either smooth, or minutely or microscopically punctate $\ldots \ldots \ldots \ldots \ldots \ldots$.

Species coarsely rugoso-punctate.

Head with two facets on vertex, behind the front ocellus; frons separated from the face by a transverse carina, the face transversely striate; thorax with irregular longitudinal carinæ.

Scape and legs honey-yellow .......... H. carinatifrons, sp. n.

Head evenly rugoso-punctate, the frons not separated from the face by a carina; no facets on vertex.

Antennæ and legs black; second joint of trochanters, extreme tips of femora, and tibiæ and tarsi honey-yellow . . . . . H. insularis, sp. n.

2. Black, polished, but with a microscopic punctation.

Scape and mandibles brownish yellow; legs reddish or honey-yellow ; first and second abdominal segments faintly longitudinally aciculated ................... H. politus, sp. n.

Black, minutely closely punctulate, opaque.

Head scarcely twice as wide as thick anteroposteriorly; the face above the antennæ deeply impressed.

Abdomen pale rufous; legs and scape yellow. H. bicolor, sp. $\mathrm{n}$. 


\section{Hadronotus carinatifrons, sp. n.}

ㅇ. Length 1.5 millim. Robust, black, shining, very coarsely rugose; scape and legs honey-yell Jw. Head very large and broad, coarsely rugose, with two facets on vertex between the ocelli; face transversely striate, separated from the frons by a transverse carina. Funicle-joint 1 and the pedicel long, about equal in length; joint 2 shorter, 3 and 4 wider than long. Thorax with irregular longitudinal raised lines posteriorly. Wings hyaline, the venation pale yellowish, the marginal vein almost as long as the stigmal. Abdomen broadly oval, sessile, evenly rugoso-punctate, the first segment and the second at base striate, the second fully twice as long as the first.

Hab. St. Vincent.

Described from a single specimen.

Hadronotus insularis, sp. n.

o 9 . Length 1.8 to 2 millim. Robust, subopaque, coarsely but evenly rugose ; eyes pubescent; second joint of trochanters, apex of femora, the tibiæ and tarsi, honey-yellow. Abdomen rugose, the first and second segments with the rugosities longitudinally directed; the extreme apices of the segments smooth, polished; second segment not twice as long as the first. Wings subhyaline, the marginal vein punctiform.

In the female the first funicle-joint is hardly as long as the pedicel, the second, third, and fourth joints transverse: in the male the antennæ are filiform, tapering towards apex, the first flagellar joint much longer than the pedicel, the second much shorter, the third slightly dilated and laterally, at base, excised, the following joints quadrate, loosely joined, the penultimate a little longer than wide, the last still longer, conical.

Hab. St. Vincent.

Described from three male and three female specimens.

\section{Hadronotus politus, sp. n.}

․ Length 0.8 millim. Black, polished, but still faintly microscopically punctate; scape, mandibles, and legs reddish or honey-yellow. Head transverse, the eyes bare. First funiclejoint very little longer than thick, much smaller than the pedicel, the three following subequal, moniliform. Thorax rounded, the mesonotum twice as wide as long, rounded anteriorly. Wings hyaline, the venation pale yellow, the marginal vein short. 
Abdomen broadly oval, the first and second segments equal, faintly aciculated.

Hab. St. Vincent.

\section{HaDroNotus Bicolor, sp. n.}

ㅇ. Length 0.6 millim. Brown-black, minutely, closely punctate; face deeply emarginated for the antennæ; scape, mandibles, legs, and abdomen rufous; pedicel two thirds the length of the funicle; first funicle-joint not longer than thick, the second, third, and fourth minute, transverse. Wings hyaline, the marginal vein very short, about twice as long as thick. Abdomen oval, punctate, the first and third segments about equal, shorter than the second, the first striate.

Hab. St. Vincent.

Described from two specimens.

IDRIS, Förster.

IDRIS ANEA, sp. n.

of ․ Length 2 to $2 \cdot 1$ millim. Black, the head and thorax with a decided æneous tinge; head sparsely punctate and striate, a smooth impunctured space above the antennæ; eyes hairy. Antennæ brown, the scape long, reddish yellow ; first funiclejoint very little shorter than the pedicel; second two thirds the length of the first; third and fourth minute. Thorax ovate, subdepressed, punctate, with a smooth, impunctate space at the middle; the mesonotum a little wider than long, arcuate anteriorly, with two distinct furrows. Wings fuscous, the venation brownblack, the marginal vein punctiform, the postmarginal but slightly developed, shorter than the stigmal, the latter short, oblique, ending in a rounded knob. Legs honey-yellow. Abdomen oblong oval or ovate, very little longer than the head and thorax together, striate, the fourth and following segments punctate; the first segment is scarcely as long as the second and has a prominence or carina at base, its tip ending in a small thorn or spur; the third segment is the longest, about one half longer than the second.

The male differs from the female in the filiform, brows-black antennæ, the scape being yellow; the first funicle-joint is the longest, much longer than the pedicel, about twice as long as thick, the following joints except the last_about equal, very little longer than thick. 
Hab. St. Vincent.

Described from two females and one male.

\section{Subfamily Platygasterine.}

Inostemma, Haliday.

Two species of this genus have been recognized, distinguished follows:-

Orbits produced into a spine-like tubercle above the eye ...................... I. bicornutus, sp. n. Orbits normal.

Legs and antennæ black ; trochanters, base of tibiæ and tarsi yellowish $\ldots \ldots \ldots \ldots \ldots$ I. simillimus, sp. $\mathbf{n}$.

INostemma BICORNuTus, sp. n.

o. Length 1 millim. Black, shining; the head and thorax microscopically punctate, the orbits produced into an acute tubercle above the eye; tibiæ piceous; tarsi and apex of pedicel yellowish. Antennæ 10-jointed, the pedicel longer than the first funicle-joint; funicle-joints 1 and 2 about equal, a little longer than thick; 3 and 4 minute, narrowed; club 4-jointed, the first three joints broader than long, the first the narrowest the third the broadest, last joint conical. Wings hyaline. Abdomen pointed, longer than the head and thorax together, the horn at base extending forward over the thorax to the vertex of head, the first segment and the second at base faintly striate.

Hab. St. Vincent.

Described from two female specimens. The acute tubercles above the eyes readily distinguish the species.

INosTEMMA SIMILLIMUs, sp. n.

0 ․ Length 0.8 millim. Black, shining; the head and thorax microscopically punctate; no tubercles over the eye; trochanters and tibiæ pale brown or yellowish, base of tibiæ and tarsi yellowish. Antennæ 10-jointed; funicle-joints 1 and 2 slightly subequal, shorter than the pedicel; 3 and 4 small, the 3rd not wider than long, the 4th twice as wide as long. Wings subhyaline, hyaline at base. Abdomen not longer than the head and thorax together, the horn extending to the base of the head.

In the male the thorax above is polished, impunctured with delicate but complete parapsidal furrows scape beneath, 
trochanters, the tibiæ, except at tips, and the tarsi honey-yellow ; the flagellum is covered with a whitish pile; the first and second joints are twice as long as thick, about equal, a little longer than the pedicel ; third joint short, triangular; club 5 -jointed, the joints oval, the last conical, longer than the penultimate.

Hab. St. Vincent.

Described from one male and one female. This species comes quite close to I. Lintnerii, Ashm., described from the District of Columbia.

\section{ACERota, Förster.}

Achrota confusa, sp. n.

of 9 . Length 1 to $1 \cdot 1$ millim. Subrobust, polished black; the head closely, microscopically punctate; antennæ and legs yellowish; scape at the middle, club, and the swollen part of the tibiæ fuscous or brown, the coxæ black; the pedicel is longer than the first funicle-joint; the second funicle-joint slightly longer than half the length of the first; the third and fourth transverse; club joints subquadrate. The thorax is polished, but faintly punctate and with two distinct furrows. Scutellum convex, finely punctate, and bounded by a carina behind. Metapleura subsericeous. Wings hyaline. Abdomen oblong-oval; in female subacute at tip, polished, with the first segment striate.

The antennæ in the male are wholly black, covered with a short white pile; the second funicle-joint is subequal with the first, the third very small; the club 5-jointed, the joints, except the long conical last joint, not longer than wide, slightly pedicellated; while the abdomen is bluntly rounded at tip.

Hab. St. Vincent.

Described from one male and one female. The male of this species could easily be mistaken for a male Inostemma.

\section{Amblitaspis, Förster.}

The species I take to belong to this genus may be tabulated as follows :-

Scutellum triangular, pubescent $\ldots \ldots \ldots \ldots \ldots$ A. triangularis, sp. n.

Scutellum produced into a long spine that projects

high over the metathorax.

Coxæ pale .......................

LINN. JOURN.—ZOOLOGY, VOL. XXV. 
Coxæ black.

Legs and antennæ black; trochanters and tarsi brownish yellow ............ A. nigricornis, sp. $\mathrm{n}$.

2. Legs and antennæ, except the club, brownish yellow or honey-yellow.

$\delta$ with the elaval joints several times longer than thick, clavate, with whorls of very long white hairs.

o with claval joints a little less than twice as long as thick. (Species large.)........ A. verticillatus, sp. $\mathrm{n}$.

0 with claval joints not more than thrice as long as thick, cylindrical, pilose.

of with claval joints not or scarcely longer than wide. (Species small.) ............. A. xanthopus, sp. n.

Ambitaspis triangularis, sp. $\mathrm{n}$.

o 9 . Length 0.65 to 0.85 millim. Polished black, impunctured; head transverse, the vertex subacute, the lateral ocelli as near to the middle ocellus as to the margin of the eye. Antennæ in female brown-black, the scape at base and beneath paler; pedicel much longer than the first funicle-joint ; second funiclejoint very slightly shorter than first, only a little longer than thick; third smaller; fourth wider than long; club 4-jointed, the joints, except the last, wider than long, the third the widest. Thorax convex, without a trace of the furrows; the scutellum triangular, subconvex, covered with a rather dense fuscous pubescence. Wings hyaline. Legs reddish yellow or brownish yellow, the swollen parts of the posterior femora and tibiæ brownish or obfuscated. Abdomen ovate; the petiole rugose, with a greyish pubescence.

In the male the scape and pedicel are yellow, the flagellum brown; the pedicel is as long as the first and second funiclejoints together; first funicle-joint shorter and slenderer than the second ; third equal, or very slightly longer than the first; club 5 -jointed, the joints loosely joined, the first moniliform, the three following elliptic-oval; legs, including the coxæ, reddish yellow or honey-yellow; the tarsi longer than their tibiæ; the hind tibial spurs distinct; abdomen oblong-oval, pubescent at base.

Hab. St. Vincent.

Described from one female and ten male specimens.

AMbLYASPIS NIGRICORNIS, sp. n.

‥ Length 2 millim. Polished black, impunctured; head 
transverse, the vertex with a delicate transverse carina behind the ocelli; the lateral ocelli not more than twice their width from the margin of the eye. Antennæ black; the funicle slender, the first joint longer than the pedicel; club slender, the joints all longer than thick. Thorax convex, without furrows. Scutellum depressed at base, and produced into a long acute yellow spine. Mesopleura, except just beneath the tegulæ, which is striate, smooth, shining. Metapleura bare and smooth, bounded by a carina above; the lower half of the carina with a fringe of pale pubescence. Metathorax with a prominent yellow median carina. Wings hyaline. Legs black; the trochanters and base of tibiæ pale brown; tarsi yellowish. Body of abdomen oval, smooth, impunctured, with a tuft of pubescence at base beneath; petiole longer than thick, impressed at the middle, fluted, subpubescent at apex and beneath.

Hab. St. Vincent.

Described from a single specimen.

Amblyaspis verticillatus, sp. $n$.

ơ 9 . Length 1.5 millim. Polished black, impunctured; the mesopleura with no striæ beneath the tegulæ; scutellum produced into a long, acute, yellow spine. Antennæ and legs honey-yellow ; club piceous, the joints very long, subclavate, as long as the basal joint of tarsi, and with whorls of long hairs; funicle long, slender, cylindrical, the second joint more than twice as long as the pedicel, the first joint short. Wings hyaline. Body of abdomen oval; the petiole about twice as long as thick, depressed at the middle, fluted, subpubescent.

The female agrees well with the male, except that the antennæ end in a 4-jointed black club, the joints of which are only slightly longer than thick; the funicle is long, slender, and cylindrical, the first and second joints being about equal and as long as the pedicel; the extreme apex of posterior femora and tibiæ obfuscated or brown; while the lateral ocelli are only their width from the margin of the eye.

Hab. St. Vincent.

Described from one male and one female.

No male is described in this genus with similar antennæ, and no difficulty will attend its recognition. It is doubtful whether the female correlated here is the opposite sex of this species. 
AMblyaspis XaNTHOPUs, sp. $n$.

․ Length 0.8 millim. Polished black, impunctured; petiole more or less yellowish. Lateral ocelli close to the margin of the eye. Thorax convex; the parapsidal furrows very slightly indicated posteriorly; scutellum produced into a long, acute, yellow spine. Antennæ and legs bright yellow ; the club brown or black; the joints, except the last, less than twice as long as thick, slightly pedicellate, with long hairs; funicle slender, the first and second joints about equal in length, shorter than the pedicel. Wings hyaline, with long cilia. Body of abdomen rotund; the petiole longer than thick, pubescent.

Hab. St. Vincent.

Described from four specimens. Comes nearest to $A$. minutus, Ashm., described from the United States.

Leptacis, Förster.

(? Ceratacis, Thoms.)

The two species recognized in this genus may be separated as follows :-

Mesonotal furrows delicate but complete.

Legs rufo-piceous; trochanters, base of tibiæ (the anterior pair entirely), and tarsi yelluwish ... L L. obscuripes, sp. n. Mesonotal furrows entirely wanting.

Legs entirely reddish yellow $\ldots \ldots \ldots \ldots \ldots \ldots$ L. erythropus, sp. n.

LePtacis obscuRIPES, sp. $\mathrm{n}$.

o. Length 0.6 millim. Black, shining; the head transverse, microscopically punctate, subopaque, the lateral ocelli being close to the border of the eye. Antennæ brownish yellow; the club brown-black, the joints oval; pedicel long and slender, nearly as long as the first and second funicle-joints united; the first funicle-joint small but longer than thick, the second thicker and about twice as long, the third small. Thorax with two distinct furrows; scutellum subconvex, foveated at base, and ending in a long awl-shaped spine; metapleura wrinkled, subpubescent, bounded by a keel above. Legs rufo-piceous; the trochanters, base of tibia, except the anterior pair which are entirely yellow, and the tarsi yellowish. Wings hyaline, the margins not fringed. Abdomen oval; the petiole wider than long, subpubescent.

Hab. St. Vincent.

Described from a single specimen. 
Leptacis ERythropus, sp. $n$.

ot Length 0.8 millim. Black, shining; the head transverse, subopaque ; the lateral ocelli close to the eye. Antennæ reddish or brownish yellow; the club brown-black, 5-jointed, pubescent, the joints longer than thick; pedicel longer than the second funiclejoint; first funicle-joint short, smaller than the third. Thorax convex, without furrows. Scutellum subconvex, bifoveated at base, and terminating in a long awl-shaped spine; a deep groove between the tegulæ and the mesonotum; metapleura covered with a silvery pubescence. Wings hyaline, fringed. Legs reddish yellow or rufous. Abdomen ovate, pubescent at base; the first segment much wider than long.

Hab. St. Vincent.

Described from two specimens.

\section{Polymecus, Förster.}

Only one species of this common genus is in the collection, which may be described as

Polymecus insularis, sp. $\mathrm{n}$.

․ Length 1.4 millim. Polished black; the frons and face finely opaquely punctate; antennæ and legs brownish yellow; the club 4-jointed, black. Mesothorax twice as long as wide, with two furrows; scutellum ending in an awl-shaped spine, pubescent at sides and foreate at base; metapleura woolly. Wings hyaline. Abdomen longer than the head and thorax together, narrowly contracted from the apex of the second segment, smooth, shining; the first segment densely woolly; the penultimate segment longer than either the antepenultimate or the ultimate; last three segments beneath finely opaquely punctate.

Hab. St. Vincent.

Described from a single specimen.

\section{Sactogaster, Förster.}

Six species of this genus are recorded from Europe and two from the United States. The two species described below are apparently quite distinct, although one is closely allied to a species from North America. The colour of the legs will aid in identification, as follows :- 
Legs black or piceous, the trochanters, base of tibiæ,

and tarsi honey-yellow or brownish yellow

Antennæ black or brown-black ............. Legs reddish yellow.

Antennæ, except the club, brownish yellow ...... S. rufipes, sp. n.

Sactogaster AFFinis, sp. $n$.

o. Length 0.8 millim. Polished black; frons and face microscopically punctate, the vertex and occiput smooth, impunctured; the lateral ocelli their width from the margin of the eye. Antennæ black or brown-black; the extreme base of the scape pale or sellowish; first and second funicle-joints subequal, the last rounded; club 4-jointed, the basal three joints wider than long. Scutellum at sides subpubescent, at tip ending in an awl-shaped spine. Metathorax and base of scutellum with a silvery-white pubescence. Wings hyaline. Legs black or piceous ; the trochanters, base of tibix, and the tarsi honey-yellow. Abdomen polished; the tail not longer than the inflated second ventral segment; the last segment pointed, about one half longer than the penultimate segment.

Hab. St. Vincent.

Described from five specimens. Closely allied to $S$. anomaliventris, Ashm., but slightly smaller, with the vertex, occiput, and mesonotum smoother, more shining, while the space between the eyes is a little narrower.

\section{SaCtOGASTER RUFJPES, sp. $\mathrm{n}$.}

q. Length 0.8 millim. Differs from S. affinis in having the scape and legs rufous or reddish yellow; the coxæ rufo-piceous, not entirely blark; the occiput subopaque; the scutellum more densely covered with a silvery pile. In the male the head is narrower, the lateral ocelli touching the border of the eye, the scutellum and metapleura bare, legs more yellowish, while the club-joints are loosely joined, twice as long as thick.

Hab. St. Vincent.

Described from two male and two female specimens.

\section{Celopelta, Ashmead.}

Antennæ in male 9-jointed, ending in a 4-jointed club; lateral ocelli as near to the front ocellus as to the margin of the eye. Scutellum cupuliform, similar to the Cynipid genus Eucoila. Female unknown. 
These simple characters readily distinguish this genus from all other genera in the group; and the genus affords another proof of the close affinities between the Proctotrypidæ and the Cynipidæ.

Celopelta mirabilis, sp. $\mathrm{n}$.

o. Length 0.8 millim. Polished black; antennæ brown, the scape yellow; legs reddish yellow, the coxæ black; metathorax with a silvery pubescence. Wings hyaline, iridescent; the hind wings rounded at apex, with long cilia ; abdomen ovate, polished; the petiole subopaque, striate, and bare.

Hab. St. Vincent.

Described from a single specimen.

\section{Synopeas, Förster.}

A single male specimen, doubtfully referred to this genus, may be called

\section{Synopeas DUBIUS, sp. $\mathrm{n}$.}

o. Length 1 millim. Polished black, impunctured; head transverse, wider than the thorax ; the occiput faintly transversely aciculated; the frons and face highly polished; lateral ocelli about their width from the margin of the eye. Antennæ brown-black ; the scape and pedicel brownish yellow ; first funicle-joint rounded, the second a little stouter and nearly twice as long as thick; club 6-jointed, the joints loosely joined, elliptic-oval, the last fusiform, nearly twice as long as the preceding. Thorax convex, with faint traces of the parapsidal furrows in front of the scutellum, the base of the middle lobe thus formed projecting slightly upon the scutellum; scutellum convex, with oblique foveæ on either side at base, the small tubercle at its tip very pubescent; metathorax subpubescent. Legs honey-yellow, the posterior tibiæ slightly dusky. Abdomen ovate, longer than the thorax; the petiole longer than thick, striate, subpubescent ; rest of the abdomen smooth, shining; the second segment with two sulci at base.

Hab. St. Vincent.

Described from a single specimen.

\section{Anopedias, Förster.}

ANOPEdias CONICA, sp. n.

of 9 . Length 0.7 to 0.8 millim. Polished black, impunctured ; lateral ocelli about twice their width from the margin of the eye, 
a little closer in the male; mesonotum with two delicate but distinct furrows ; metapleura bare or subpubescent ; first and second funicle-joints about equal, a little longer than thick, shorter than the pedicel, the third elongate, the fourth short; club cylindrical, the joints about twice as long as thick, or very little longer. Wings hyaline, fringed. Legs black; trochanters, base of tibiæ, and the tarsi variable from a piceous to yellow. Abdomen conic-ovate, longer than the head and thorax together, petiolate; the petiole striate; rest of the abdomen smooth, polished; the second segment with two long sulci at base, one on each side.

Hab. St. Vincent.

Described from one male and ten female specimens. Comes very close to $A$. error, Fitch, but is smaller, with the joints of the antennæ relatively different.

\section{Trichacis, Förster.}

Trichacis rubicola, Ashm., Monog. N.A. Proctotrypida, p. 296.

Of this species there are two specimess agreeing in every particular with the types in the U.S. National Museum. It was reared from a Cecidomyid gall on Blackberry.

\section{Polygnotus, Förster.}

Of this genus, as now limited, five species have been reeognized, which may be distinguished by the following table:-

Males.............................

2.

Females.

Mesonotal furrows distinct posteriorly for half the length of the mesonotum.

Head much wider than thorax, the lateral ocelli twice their width from the eyemargin.

Legs black or piceous black, the trochanters, base of tibiæ, and tarsi pale brown; antennæ brown-black, the scape pale at extreme base...................

Mesonotal furrows wanting or but slightly indiP. meridionalis, sp. и. cated posteriorly.

Head not so wide, the lateral ocelli not much more than their width from the eye-margin. Legs brownish yellow, the coxæ black, the femora more or less piceous; antennæ brown, the scape brownish yellow....

P. insularis, sp. n. 
2. Mesonotal furrows indicated posteriorly.

Head wider than the thorax, the lateral ocelli twice their width from the eyemargin.

Legs piceous; the trochanters, base of tibiæ, and tarsi yellowish $\ldots \ldots \ldots \ldots \ldots \ldots$.

P. meridionalis, sp. $\mathrm{n}$.

Lateral ocelli not twice their width from the eye-border.

Coxæ black.

Legs black; trochanters, base of tibiæ, and tarsi piceous or brown.

Antennæ black, the club-joints $1 \frac{1}{2}$ times as long as thick .......... Legs honey-yellow.

Antennæ brown-black, the scape yellowish, the club-joints twice as long as thick $\ldots \ldots \ldots \ldots \ldots$.

Legs piceous; trochanters, base and tip P. insularis, sp. n. of tibiæ, and the tarsi yellowish.

Antennæ brown-black, short, the clubCoxæ pale. joints wider than long......... P. laticlavus, sp. n.

Scape and legs reddish- or honey-yellow ; club 6-jointed, the joints, except the last, moniliform .............

P. gracilicornis, sp. n.

P. pallidicoxalis, sp. $\mathrm{n}$.

Polygnotus meridionalis, sp. $\mathrm{n}$.

o 오. Length 0.9 to 1 millim. Polished black, impunctured; lateral ocelli twice their width from the eye-border; antennæ brown-black, the scape at extreme base and the minute first funiclejoint yellowish; the flagellum with sparse white hairs; second funicle-joint as large as the pedicel, a little swollen, third small ; club 5-jointed, the joints loosely joined, very little longer than wide. Thorax with two delicate furrows on the posterior half of the mesonotum; scutellum highly convex, subpubescent; metathorax pubescent. Wings hyaline, with a short fringe at apex. Legs black or piceous ; the trochanters, base of tibiæ, and the tarsi pale brown or yellowish. Abdomen oblong-oval, the petiole striate, pubescent beneath.

The female is the larger, more robust form, with the head much broader than in the male, the club-joints scarcely longer than wide, the scutellum higher, the abdomen ovate, while the legs are blacker.

Hab. St. Vincent.

Described from one male and one female. 
Polygnotus insularis, sp. $\mathrm{n}$.

ơ 오. Length 1 to $1 \cdot 1$ millim. Polished black, impunctured; lateral ocelli not twice their width from the eye-border; antennæ dark brown, the scape brownish yellow, the club-joints a little wider than long. Thorax without furrows or but slightly indicated posteriorly, with two opaque pubescent spots just in front of the scutellum. Scutellum high, convex, polished. Metapleura finely striate, subpubescent. Wings hyaline, with a short fringe. Legs brownish yellow or yellowish, the coxæ black, the femora in female a little piceous. Abdomen oblong-oval, about as long as the head and thorax together, with the first segment striate.

The male is the smaller, and differs in having all the legs honeyyellow, with the antennal club 5-jointed, the joints nearly or quite twice as long as thick, the last conical, three times as long as thick.

Hab. St. Vincent.

Described from one male and one female.

Polygnotus gracilicornis, sp. n.

ot. Length 1 millim. Polished black, impunctured; lateral ocelii only about their width from the eye-border ; antennæ black ; the first funicle-joint very small and slender, but still longer than thick ; the second somewhat swollen and twisted, about twice as long as thick, the third smaller ; club slender, the joints, except the last, once and a half as long as wide, the last conical, twice as long as the penultimate. Thorax with delicate furrows posteriorly. Scutellum convex, polished, faintly pubescent. Legs black, anterior tibiæ and all tarsi yellowish, trochanters and base of middle and posterior tibiæ piceous or yellowish. Abdomen oblong, as long as the thorax, polished, with the first segment striate, the second at base with two striate foveolæ.

Hab. St. Vincent.

Described from a single specimen.

\section{Polygnotus laticlatus, sp. n.}

o. Length 0.65 millim. Differs principally in the joints of the antennæ: the first and second funicle-joints are closely united, the second being much the larger; the first club-joint is oval, the three following broadly transverse, the last oblong; the legs are piceous, the trochanters, tips of anterior tibiæ, the base of middle 
and hind tibiæ, and all tarsi yellow; while the abdomen is oval, shorter than the thorax.

Hab. St. Vincent.

Described from a single specimen.

\section{Polygnotus pallidicoxalis, sp. $\mathrm{n}$.}

o. Length 0.9 millim. In this species the legs are pale brownish or honey-yellow, the hind coxæ alone at base being slightly dusky; antennæ brown, the scape yellow; the first funicle-joint is minute, transverse, the second as large as the pedicel, the third a little smaller; the club-joints, except the last, moniliform, very little, if any, longer than thick; the last conic ovate, about twice as long as the preceding joint; all the club-joints are briefly pedicellate and covered with sparse white hairs.

Hab. St. Vincent.

Described from a single specimen.

Subfamily Diapritna.

Tribe i. SPILOMicRINI.

IDIOTYPa, Förster.

IDIOTYPA PALLIDA, sp. n.

o ㅇ. Length $1 \cdot 8$ to 2 millim. Reddish-testaceous, smooth, shining; eyes and antennal club black or brown-black; legs yellow-testaceous. Antennæ in female 12-jointed, the club robust, 4-jointed, black ; funicle-joints gradually widened toward the club, the first joint a little longer and thinner than the pedicel ; club-joints large except the last, transverse-moniliform, the last large, conic: in male 13-jointed, long, filiform, the pedicel rounded, the flagellar joints about thrice as long as thick, loosely joined, the first and last a little longer than the others. Thorax with two furrows; scutellum trifoveated at base, the lateral foveæ being towards one side of the apex of the middle fovea; metathorax rugose, pubescent, the posterior angles subacute, the central carina produced into a blunt spine. Wings hyaline, pubescent, ciliated, the marginal and basal veins distinct, the marginal thrice as long as thick; the stigmal vein short, with a backward directed branch from its tip. Abdomen oval, the netiole in the male about twice as long as thick, a little shorter 
and stouter in the female, striate; rest of abdomen smooth, polished, the second segment at base sulcate, with some striæ at extreme base.

$H a b$. St. Vincent.

Described from one male and two female specimens.

\section{Hemilexis, Förster.}

Hemilexis latipennis, sp. n.

o. Length 1 millim. Brownish, smooth, impunctured, the metathorax and legs yellowish; head black above. Antennæ 13-jointed, pale brownish, the scape yellowish; first and second flagellar joints elongate, the second two thirds the length of the first; joints beyond to the last elliptic-oval, slightly pedicellate, pubescent, the last conic. Thorax with two delicate furrows; scutellum with a single large for ea at base ; metathorax punctate, with a median carina, and with the posterior angles produced into small acute teeth. Wings very broad, hyaline, pubescent, with long cilia, the apical margin very slightly emarginate or sinuate, the marginal vein punctiform, the stigmal vein a little more than thrice as long as thick. Abdomen oval, petiolated, the petiole about thrice as long as thick, faintly striate; body smooth, polished, the second segment with a small median sulcus at base.

Hab. St. Vincent.

Described trom a single specimen.

\section{Hemilexodes, Ashmead.}

Hemilexodes Filiformis, sp. $n$.

o. Length 0.9 millim. Polished black; scape, metathorax, petiole, and legs honey-yellow. Thorax without furrows; scutellum with a fovea at base; metathorax rugoso-punctate, the posterior angles acute. Antennæ 13-jointed, long, filiform, pilose; the joints of the flagellum all long, cylindrical, the second a little shorter than the first, very slightly dilated towards tip. Wings hyaline, with long cilia, the apical margin very slightly sinuate; the venation as in Hemilexis, the marginal vein being punctiform and the stigmal about four times as long as thick.

Hab. St. Vincent.

Described from a single male specimen. 


\section{Tropidopsis, Ashmead.}

Tropidopsis Clavata, sp. $\mathrm{n}$.

0 . 9 . Length $1 \cdot 3$ to $1 \cdot 5$ millim. Brownish red or ferruginous, smooth, polished, impunctured; antennæ, except the club, and legs paler, more yellowish. Antennæ in female 12-jointed, ending in an abrupt 3-jointed black club, the first two joints of which are quadrate, the last oblong; funicle 7 -jointed, slender, the first joint about twice as long as the second, the following joints not longer than thick, the last two or three slightly transverse; pedicel obconic, much longer and stouter than the first funicle-joint. Head globose, the face flat, with a very delicate carina at the sides; eyes large, rounded. Scutellum with a single fovea at base. Metathorax with a central carina, emarginate behind, the angles a little prominent. Abdomen oblongoval, the petiole a little longer than thick, pubescent. Wings hyaline, fringed, the submarginal vein reaching the costa at about, the middle of the wing and ending in a subtriangular marginal vein; basal nervure present, straight.

The male is slightly smaller, the head more transverse, without the delicate carinæ at the sides of the face; the antennæ longer than the body, 14-jointed, filiform; the flagellar joints, except the last, elliptic-oval, pubescent, the first three joints being a little more slender than the following; metathorax emarginate behind, pubescent, with a prominent central carina; while the abdominal petiole is almost twice as long as thick, eylindrical, striate, and pubescent.

Hab. St. Vincent.

Described from one male and one female.

\section{Paramesius, Westwood.}

\section{Paramesius thoracicus, $\mathrm{sp} . \mathrm{n}$.}

o 9 . Length 1.5 to 1.8 millim. Head and body of abdomen polished black; thorax variable, from a dark honey-yellow to brown or piceous ; the male the paler, the female the darker, with the pleura and metathorax sometimes black; scape, petiole, and legs reddish yellow or honey-yellow. Antennæ in female 13jointed, clavate, the scape very long; the flagellum gradually becomes brown-black at tip, the joints gradually increasing in size after the sixth, submoniliform, the last large, conic, nearly thrice as long as the penultimate; in the male filiform, 13- 
jointed; the flagellar joints, after the first, all elongate, cylindrical, the first very small, smaller than the pedicel, the second thrice as long as the pedicel, excised at base. Thorax smooth, shining, with two furrows; scutellum with a large fovea at base; metathorax rugose, with a sharp median carina. Wings hyaline, pubescent, ciliate; the renation brown, the marginal vein thrice as long as thick, a little narrower at base than at tip; stigmal vein scarcely developed, not longer than thick; basal vein subobsolete or entirely absent. Abdomen in female conic-ovate, the petiole about twice as long as thick, striate ; in male pear-shaped, the petiole about four times as long as thick; body of abdomen in both sexes highly polished.

Hab. St. Vincent.

Described from four male and four female specimens.

\section{Spilomicrus, Westwood.}

The following table will assist in recognizing the species in this genus.

Wings subfuscous, the basal vein absent.

Legs dark rufous, the coxæ black or piceous.

Antennæ brown-black, the second flagellar joint

shorter than the first, excised at base ...... S. aneurus, sp. n. Wings hyaline, the basal vein present.

Legs, including coxæ, reddish yellow.

Antennæ pale brown, the scape and pedicel yellowish, second flagellar joint not excised at base $\ldots \ldots \ldots \ldots \ldots \ldots \ldots \ldots \ldots \ldots$ S. vulgaris, sp. n.

Spilomicrus aneurus, sp. n.

․ Length $3 \cdot 2$ millim. Polished black, impunctured; head globose, the cheeks woolly behind; frontal prominence large, the face with a $\Lambda$-shaped sulcus; mandibles black or piceous. Antennæ 13-jointed, black, much thickened towards tips; scape about as long as the first four funicle-joints combined, curved; first funicle-joint longer than the pedicel, the latter equal with the second funicle-joint; joints from the fifth to the penultimate quadrate moniliform, the last conic, not longer than, and scarcely as wide as, the penultimate. Thorax with two furrows; the pronotum woolly at sides, and produced anteriorly above into a short neck; scutellum with a subapical transverse furrow, sulcate at sides, and with two large foveæ at base; postscutellum closely punctate, tricarinate; metathorax rugose, pubescent, with an 
acute median carina, rather prominent angles posteriorly, and with lateral carinæ. Legs dark rufous, pubescent, the coxæ piceous or black. Wings subfuscous, pubescent, the submarginal vein reaching the costa at half the length of the wing, the maruinal vein about three times as long as thick, the stigmal vein very short, not longer than thick. Abdomen oblong-oval, polished, pilose at apex; the petiole long, three times as long as thick, fluted, woolly beneath.

o. Length 3.5 to 4 millim. Agrees well with the female except that the scutellum has a transverse row of coarse punctures at the apex, the last ventral segment is biforeate, with a central carina, while the antennæ are long, filiform; the scape is finely striated beneath, and about as long as the pedicel and first flagellar joint united, second funicle-joint about two thirds the length of the first, excised at base ; the joints beyond the last very nearly equal in length.

\section{Hab. St. Vincent.}

Described from one female and five male specimens.

\section{Spilomicrus vUlgaris, sp. $\mathrm{n}$.}

ㅇ. Length 1.5 to 2.5 millim. Polished black, impunctured; head globose, sparsely pilose, the cheeks with a tuft of wool behind; face smooth, not sulcate; mandibles yellowish. Antennæ 13-jointed, brownish yellow, with only three or four terminal joints dusky or black; scape about as long as the first five funiclejoints united ; first funicle-joint not or very little longer than the pedicel, the latter much the stouter; funicle-joints 2 to 4 subequal, shorter than the first; joints 5 and 6 moniliform; club 5 -jointed, the joints transverse or subquadrate moniliform, the first pale, the last three or four black. Thorax with two furrows, the pronotum woolly at sides anteriorly; scutellum with two large fover at base, a sulcus at the sides, and a transverse punctate line at apex; metathorax rugose, pubescent, with an acute ridge at the middle and carinæ laterally. Legs entirely reddish or brownish yellow. Wings hyaline, the basal nervure distinct, rarely subobsolete. Abdomen oblong-oval, polished, pilose at tip, the last ventral segment minutely punctate; petiole long, coarsely fluted, pubescent above and beneath.

o. Length 2 to 2.5 millim. Differs principally in the filiform brown antennæ, the scape and pedicel alone being yellow; the scape is as long as the first and second funicle-joints united; 
the latter are about equal in length, the second not excised at base, the joints beyond to the last being very slightly and gradually subequal; last ventral segment piceous, but with two small punctures at base.

Hab. St. Vincent.

Described from 22 male and 14 female specimens.

\section{Tribe ii. Diaprinni.}

\section{Galesus, Curtis.}

Galesus bipunctatus, sp. n.

ㅇ. Length $2 \cdot 2$ to $2 \cdot 4$ millim. Polished black, impunctured, with sparse white hairs ; head oblong, with a margined angulation in front of each eye, the space between it and the eye with a row of punctures; between these angulations there is another margined space enclosing the ocelli; vertex with six sinall punctures ; face prolonged, with deep broad sulci beneath the eyes; frontal prominence with a median sulcus. Antennæ black, 12-jointed, the scape angulately dilated a little beyond the middle; flagellar joints, after the fourth, transverse-moniliform, loosely joined and gradually widened towards tip of flagellum, the last joint ovate, twice as long as the penultimate. Thorax with two furrows, the middle lobe with two small punctures at base and two at the middle; scutellum truncate and with two punctures at tip, a broad sulcus at sides and two large foveæ at hase; metathorax grooved, pubescent. Wings folded, deeply emarginate at apex. Legs rufous or reddish yellow, the coxæ black. Abdomen oblongoval, polished black; the petiole about twice as long as thick, fluted and pubescent.

0 . Length 2.5 millim. In this sex the head is shorter, only a little longer than wide, with the ridges and punctation as in the female. The antennæ are 14-jointed, filiform, as long as the body, the pedicel and first funicle-joint being brownish yellow or brown, the rest of the antennæ black; the second funicle-joint is a little thicker and shorter than the first, excised at base; the joints beyond a little longer, very little more than thrice as long as thick, the last joint being much longer than any of the others.

Hab. St. Vincent.

Described from two male and two female specimens. 


\section{Loxotropa, Förster.}

\section{Loxotropa columbiana, Ashm.}

A single specimen of this species, from St. Vincent, cannot be separated from the type collected in the District of Columbia.

\section{LoXotropa THORACICA, sp. n.}

․ Length 0.8 millim. Head and abdomen polished black; thorax brownish piceous; antennæ, except the abrupt 3 -jointed club which is black, and legs yellow. The head is a little longer than wide, with angulated ridges before the eyes. The first funicle-joint twice as long as the second, the following joints not longer than thick; two basal joints of club quadrate, the last oblong. Wings hyaline, pubescent. Abdomen oblong-oval, the petiole pubescent.

Hab. St. Vincent.

Described from a single specimen.

\section{Tropidopria, Ashmead.}

The species belonging to this genus may be separated by the aid of the following table :-

\section{Females.}

Head and abdomen black, the thorax reddish.

Antennæ with an abrupt 3-jointed club, the last two joints being black .......... T. nigriceps, sp. n.

Wholly reddish or dark honey-yellow.

Antennæ with the club 5-jointed, gradually formed.

Two last club-joints black ........... T. pallida, sp. n.

\section{Males.}

Head and abdomen black, the thorax piceous, the petiole short, finely striate.

Scutellum acutely triangular ............ T. triangularis, sp. $\mathbf{n}$. Head and abdomen black, thorax reddish, the petiole long, coarsely fluted.

Scutellum not acutely triangular ........ T. nigriceps, sp. n.

Wholly reddish or dark honey-yellow ........ T. pallidaysp. n.

\section{Tropidopria triangularis, sp. $\mathrm{n}$.}

o. Length 1.2 millim. Head and abdomen black, polished; thorax piceous, more or less blackish above. Antennæ 14-jointed,

LINN. JOURN.-ZOOLOGI, VOL. XXV. 
pedicellate-nodose, verticillate, bright yellow, the nodes piceous. Scutellum acutely triangular, carinated, with a profound fovea at base. Metathorax rugose, carinate, subpubescent. Wings hyaline, strongly fringed. Legs, including coxæ, honey-yellow. Body of abdomen oval, black, shining; the petiole short, hardly twice as long as thick, yellowish, finely striate.

Hab. St. Vincent.

Described from two male specimens.

Tropidopria NIGRICEPs, sp. $\mathrm{n}$.

$\checkmark$. . Length 2 to $2 \cdot 5$ millim. Head and thorax black, polished, impunctured; thorax reddish; the scutellum in female subobsoletely carinate, with a small fovea at base, in male with a large fovea at base and distinctly carinate; metathorax rugosopunctate, subpubescent, the middle carina produced into a short acute spine. In the female the antennæ, except the last two joints which are black, the legs, petiole, and tip of abdomen are honey-yellow; the club is abrupt, 3-jointed; the funicle slender; the petiole about $2 \frac{1}{2}$ times as long as thick, cylindrical, faintly striate; body of abdomen conic ovate. In the male the scape, pedicel, and legs are honey-yellow or reddish yellow; the flagellum piceous black, nodose-pedicellate, with whorls of long hairs ; petiole coarsely fluted, fully four times as long as thick; body of abdomen oblong-oval, polished black. Wings in both sexes hyaline, strongly fringed.

Hab. St. Vincent.

Described from one female and four male specimens.

Tropidopria PALLIDa, sp. n.

o 9 . Length $1 \cdot 8$ to $2 \cdot 1$ millim. Uniformly light brownish red, polished; scutellum foveate at base, faintly carinate at tip ; metathorax finely rugose, pubescent, with a prominent median carina. Iu the male the scape, pedicel, and legs are yellowish; flagellum darker, nodose-pedicellate, with whorls of long hairs; petiole $2 \frac{1}{2}$ times as long as thick, finely rugose, pubescent. In the female only the last two antennal joints are black, the club being gradually formed, 5 -jointed; petiole scarcely twice as long as thick, pubescent; body of abdomen pointed at tip. Wings in both sexes hyaline, strongly fringed.

Hab. St. Vincent.

Described from six male and twelve female specimens. 


\section{DiAPRIA, Latreille.}

Diapria mellea, sp. $\mathrm{n}$.

o 9 . Length 1 to $1 \cdot 1$ millim. Dark honey-yellow or light brownish red, polished, impunctured; antennæ and legs honeyyellow. Club of antennæ in female 4-jointed, gradually formed, the last joint large, conic or oblong, black, closely joined to the penultimate, the other two joints loosely joined. Abdomen ovate, the petiole scarcely once and a half as long as thick, pubescent.

In the male the flagellum is long, cylindrical, with whorls of long hairs ; the joints, except the first, all long, cylindrical, as long as the scape, the first joint only two thirds the length of the scape. Abdomen oval, the petiole a little more than twice as thick. Wings hyaline, strongly fringed in both sexes. Scutellum with a rounded fovea at base.

$H a b$. St. Vincent.

Described from two male and three female specimens.

\section{Trichopria, Ashmead.}

The following table will aid in separating the three species in this genus.

\section{Females.}

Species pale, or with thorax pale

Species black, the pleura alone sometimes piceous.

Pleura black; antennæ blach ; the club 4-jointed, loosely joined, the joints increasing in size ;

thickened parts of the legs piceous ...... T. insularis, sp. n.

Pleura piceous; antennæ, except the last three joints of club, and legs honey-yellow....... T. pleuralis, sp. n.

2. Thorax pale brownish piceous; head and abdomen black.

Scutellum with two minute subobsolete foveæ at base; antennæ, except the last two joints, and legs brownish yellow

T. atriceps, sp. $\mathrm{n}$.

\section{Males.}

Species with the thorax pale $\ldots \ldots \ldots \ldots \ldots \ldots \ldots$

Species black, the pleura alone sometimes piceous.

Pleura black; scape, pedicel, and legs reddish yellow; second flagellar joint longer than the first, curved and angulate toward one side, the joints beyond rounded-moniliform, shorter than the first, with whorls of bristly hairs .. T. insularis, sp. $\mathrm{n}$. 
Pleura piceous; scape, pedicel, and legs honeyyellow; second flagellar joint very slightly excised at base, but not angulate, the joints beyond oval-moniliform, longer than the first, pubescent ......................

T. pleuralis, sp. n.

2. Thorax reddish, head and abdomen black.

Scutellum with a large fovea at base; flagellar joints after the second rounded-moniliform, with whorls of bristles, first joint longer than the second

T. atriceps, sp. n.

TRICHOPRIA INSULARts, sp. $n$.

ơ 우. Length $1 \cdot 2$ to $1: 3$ millim. Polished black; legs piceous, the trochanters, base of tibiæ, and the tarsi yellowish. Head globose, as wide as the thorax. Antennæ 12-jointed, piceous black; scape as long as the pedicel and first two funicle-joints united ; funicle 6-jointed, the joints slender, the last two a little thicker than the preceding; club 4-jointed, the joints increasing in size, the last oblong. Mesonotum not longer than wide; scutellum with a large fovea at base connected with a delicate grooved line at sides; metathorax short, finely rugose, with a median carina, and subpubescent. Wings hyaline, strongly fringed. Abdomen ovate, pointed at tip, polished black, the tip piceous, with sparse long hairs; petiole cylindric, twice as long as thick.

In the male the antennæ are 14-jointed, filiform-moniliform, pale brownish, the scape and pedicel yellow; second flagellar joint a little longer and stouter than the first, curved and angulate towards one side; the joints beyond to last rounded-moniliform, shorter than the first, all with whorls of stiff bristles; legs, including coxæ, reddish yellow; petiole not longer than thick, pubescent; body of abdomen oval.

Hab. St. Vincent.

Described from one male and one female.

Trichopria pleuralis, sp. $n$.

o 9 . Length 1 to $1 \cdot 2$ millim. Closely resembles T. insularis; but in the female the antennæ, except the 4-jointed club, the legs, and the abdominal petiole are yellow; the mesothoracic pleura piceous; the petiole is not longer than thick and pubescent; while the male differs in having the flagellum brown, the joints after the second oval-moniliform, longer than the first, with a short pubescence, the second joint being only slightly excised at base, and not angulate. 
Hab. St. Vincent.

Described from one male and one female.

Trichopria atriceps, sp. $n$.

o ․ Length $1 \cdot 3$ to 1.5 millim. Head and abdomen polished black; thorax pale brownish piceous or reddish; antennæ in female (except the last two joints of the club) and the legs yellow or pale brownish yellow. Head a little longer than wide, subglobose. The antennæ end in a 3-jointed club, the joints increasing in size, the last joint oblong ; funicle slender, 7 -jointed, the joints scarcely longer than thick. Collar, metathorax, and the short petiole woolly. Scutellum smooth, with two minute subobsolete foveæ at base. Body of abdomen conic ovate.

The male (or what is taken to be the opposite sex) is larger, and agrees in colorational detail with the female; but the antennæ are 14-jointed, filiform-moniliform, the first flagellar joint being a little longer than the second, the second slightly swollen, the joints beyond rounded-moniliform, with whorls of long bristles, while the scutellum has a large, smooth, shallow fovea at base.

Hab. St. Vincent.

Described from one male and two female specimens.

\section{Phenopria, Ashmead.}

Two species in this genus have been recognized as follows :-

\section{Females.}

Dorsal abdominal segment 5 much longer than 3 and 4 united.

Antennæ black; swollen parts of legs piceous.... P. subclavata, sp. n. Dorsal abdominal segment 5 not longer than 3 and 4 united.

Antennæ, except the scape and club, honey-yellow ; legs bright yellow, tips of femora and tibiæ piceous .................... simillima, sp. n.

\section{Males.}

Basal 3 joints of antennæ yellow, the flagellar joints after the second rounded-moniliform.

Legs honey-yellow ................. P. subclavata, sp. n.

Basal joint of antennæ yellow, the flagellum brownblack, the joints after the second oval.

Legs and petiole yellow, tips of femora and tibiæ piceous . ................... P. simillima, sp. n. 
Phenopria subclatata, sp. n.

o 9 . Length 1 to $1 \cdot 2$ millim. Polished black, impunctured; antennæ in female 12-jointed, black, enlarged towards tip, the funicle-joints after the second a little transverse, very gradually increasing in width to club; club 3 -jointed, the first two joints nearly equal, transverse, the last oblong, as long as the two preceding together, and stouter; legs piceous, the trochanters, base of tibiæ, and tarsi yellow. Scutellum longer than wide at base, convex, without a fovea at base. Metathorax and petiole pubescent, the latter short. Abdomen conic-ovate, as long as or a little longer than the thorax, the last segment conical, 5th segment much longer than the 3rd and 4th united. Wings hyaline, strongly fringed.

In the male the first three or four basal joints of antennæ and the legs are yellow ; rest of the antennæ pale brownish, the flagellar joints after the second rounded-moniliform, with bristly hairs; the second joint is a little longer than the first, very slightly bent; body of abdomen oblong-oval, truncate at tip.

Hab. St. Vincent.

Described from two male and two female specimens.

Phenopria simillima, sp. n.

o ㅇ. L Length 0.65 to 0.90 millim. Differs from $P$. subclavata in its smaller size and colour of antennæ and legs; the antennæ in the female, except the scape and the club, are pale yellow; the swollen parts of the legs are piceous; while the 5th abdominal segment is not longer than the $3 \mathrm{rd}$ and 4 th united.

The male differs in having the scape alone yellow, the flagellum being black, with the joints after the second elliptic-oval, not rounded; the second joint is a little thicker than the first and very slightly excised at base.

Hab. St. Vincent.

Described from one male and one female.

Addendum.-On p. 77, for Anectoclis sp. read Anectoctis rufipes, Howard. 


\section{$2 \mathrm{BHL}$ Biodiversity Heritage Library}

Riley, Charles V., Ashmead, William H., and Howard, L. O. 1894. "Report upon the parasitic Hymenoptera of the island of St. Vincent." The Journal of the Linnean Society of London. Zoology 25, 56-254.

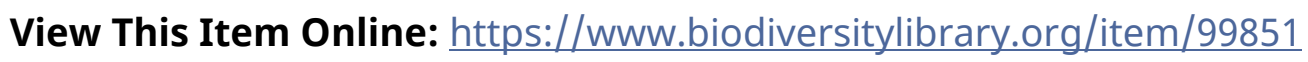

Permalink: https://www.biodiversitylibrary.org/partpdf/70361

\section{Holding Institution}

Smithsonian Libraries

\section{Sponsored by}

Biodiversity Heritage Library

\section{Copyright \& Reuse}

Copyright Status: Public domain. The BHL considers that this work is no longer under copyright protection.

This document was created from content at the Biodiversity Heritage Library, the world's largest open access digital library for biodiversity literature and archives. Visit BHL at https://www.biodiversitylibrary.org. 